\title{
Analysis of Near-Term Spent Fuel Transportation Hardware Requirements and Transportation Costs
}
P. M. Daling
R. L. Engel

January 1983

Prepared for the U.S. Department of Energy under Contract DE-AC06-76RLO 1830

Pacific Northwest Laboratory Operated for the U.S. Department of Energy by Battelle Memorial Institute 


\title{
DISCLAIMER
}

This report was prepared as an account of work sponsored by an agency of the United States Government. Neither the United States Government nor any agency thereof, nor any of their employees, makes any warranty, express or implied, or assumes any legal liability or responsibility for the accuracy, completeness, or usefulness of any information, apparatus, product, or process disclosed, or represents that its use would not infringe privately owned rights. Reference herein to any specific commercial product, process, or service by trade name, trademark, manufacturer, or otherwise, does not necessarily constitute or imply its endorsement, recommendation, or favoring by the United States Government or any agency thereof. The views and opinions of authors expressed herein do not necessarily state or reflect those of the United States Government or any agency thereof.

\author{
PACIFIC NORTHWEST LABORATORY \\ operated by \\ BATTELLE \\ for the \\ UNITED STATES DEPARTMENT OF ENERGY \\ under Contract DE-AC06-76RLO 1830
}

Printed in the United States of America Available from

National Technical Information Service

United States Department of Commerce 5285 Port Royal Road

Springfield, Virginia 22151

NTIS Price Codes

Microfiche A01

\begin{tabular}{ll}
\multicolumn{2}{c}{ Printed Copy } \\
Pages & Price \\
& Codes
\end{tabular}

001-025

A02

026-050

051-075

076-100

$10 \div-125$

126-150

$151-175$

176-200

201-225

226-250

251-275

276-300 
PNL -4575

UC-85

\author{
ANALYSIS OF NEAR-TERM \\ SPENT FUEL TRANSPORTATION \\ HARDWARE REQUIREMENTS \\ AND TRANSPORTATION COSTS
}

P. M. Daling

R. L Engel

January 1983

Work funded by the U.S. Department of Energy through the Commercial Spent Fuel Management Program under

Contract DE-AC06-76RL0-1830

Pacific Northwest Laboratory

Richland, Washington 99352 
$\rightarrow$ 


\section{PREFACE}

On December 20, 1982, the Nuclear Waste Policy Act of 1982 passed both the United States Senate and House of Representatives and is expected to be signed by President Reagan. The bulk of this study was completed prior to passage of the Nuclear Waste Bill and therefore, is not entirely cognizant of the terminology and final provisions of the Bill. The most important provisions in the $B i l l$ relating to spent fuel transportation to Federal interim storage include the following:

o Capacity - 1900 MTU of spent fuel; this is not approached in any of the scenarios in this report

o Title - Government assumes title to the fuel at the reactor sites

o Transportation - Government is responsible for transportation from reactors to storage sites

- Transfer requirement - Removal of the fuel is required within 3 years after repository or Monitored Retrievable Storage Facility is available.

The above provisions do not significantly affect the results obtained in this study. Further analyses could be performed to identify new scenarios and impacts of the Bill on the future spent fuel transportation system requirements. 

$\underline{\text { ABSTRACT }}$

Transportation of commercial spent fuel from light water reactors (LWRs) is expected to significantly increase in the 1980s and 1990s. Overflow spent fuel from reactors with inadequate storage capacity could be placed in Federal interim storage facility as early as 1984. This study examined potential competition for the use of available transportation casks and costs to determine impacts on this program. A computer model was developed to quantify the transportation hardware requirements and transportation costs associated with shipping spent fuel in the commercial nuclear fuel cycle in the near future. Alternative spent fuel management scenarios are examined to determine their effect on transportation cost and hardware requirements, including investigation of the impacts of delaying the opening of a fuel reprocessing plant, alternative spent fuel shipping systems, and increased utilization of truck systems. The current shipping cask fleet size is examined to determine its adequacy to provide the needed services for the above facilities. Results are presented for alternatives in transportation hardware configurations and spent fuel management strategies.

Results from this study indicate that alternative spent fuel shipping systems (consolidated or disassembled fuel elements and new casks designed for older fuel) will significantly reduce the transportation hardware requirements and costs for shipping spent fuel in the commercial nuclear fuel cycle, if there is no significant change in their operating/handling characteristics. It was also found that a more modest cost reduction results from increasing the fraction of spent fuel shipped by truck from $25 \%$ to $50 \%$. Larger transportation cost reductions could be realized with further increases in the truck shipping fraction.

Using the given set of assumptions, it was found that the existing spent fuel cask fleet size is generally adequate to perform the needed transportation services until a fuel reprocessing plant (FRP) begins to receive fuel (assumed in 1987). Once the FRP opens, up to 7 additional truck systems and 16 additional rail systems are required at the reference truck shipping fraction of $25 \%$. For the $50 \%$ truck shipping fraction, 17 additional truck systems and 9 
additional rail systems are required. If consolidated fuel only is shipped ( $25 \%$ by truck), 5 additional rail casks are required and the current truck cask fleet is more than adequate until at least 1995. Changes in assumptions could affect the results.

Transportation costs for a Federal interim storage program could total about $\$ 25 M$ if the FRP begins receiving fuel in 1987 or about \$95M if the FRP is delayed until 1989. This is due to an increased utilization of Federal interim storage facility from 350 MTU for the reference scenario to about 750 MTU if reprocessing is delayed by two years. 


\section{ACKNOWLEDGEMENTS}

The authors would like to express their appreciation to Mr. Billy Cole, Pacific Northwest Laboratory and Mr. Frank Votaw, Rockwell Hanford Operations for their valuable contributions to this study. Mr. Cole provided assistance and guidance regarding the development of transportation costs. Mr. Votaw of the DOE/Hanford Traffic Manager's Office provided assistance and research in developing the spent fuel transportation costs. 


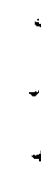




\section{TABLE OF CONTENTS}

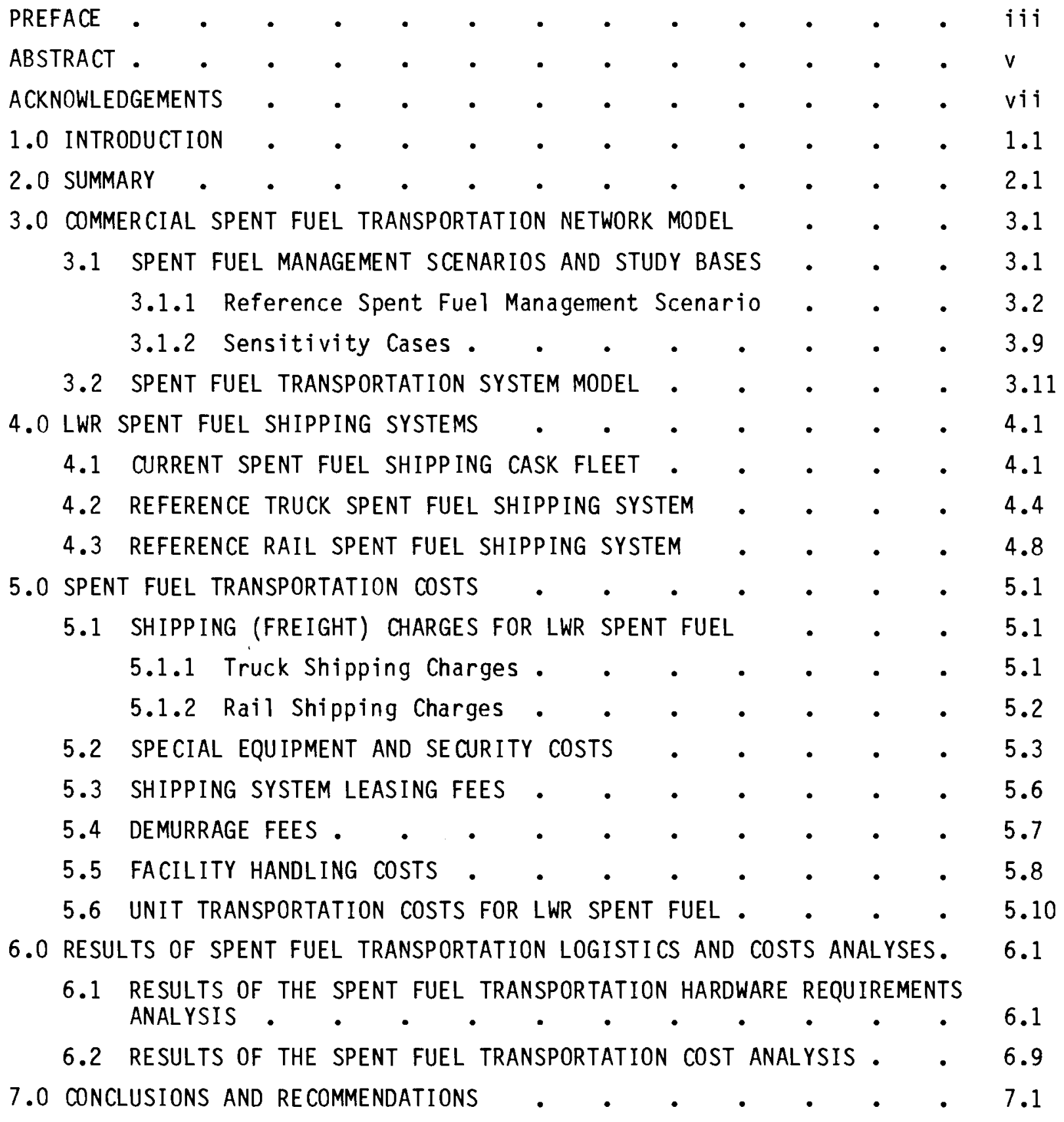




\section{REFERENCES}

APPENDIX A - QUANTITIES OF LWR SPENT FUEL REQUIRING TRANSPORTATION SERV ICES IN THE NEAR FUTURE $\quad \cdot \quad \cdot \quad \cdot \quad \cdot \quad \cdot \quad \cdot \quad$ A.1

APPENDIX B - INPUT REQUIREMENTS FOR THE SPENT FUEL TRANSPORTATION

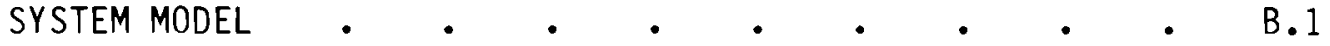

APPENDIX C - FREIGHT CHARGE RATES FOR TRUCK AND RAIL SPENT

FUEL SHIPMENTS $\bullet \quad \cdot \quad \cdot \quad \cdot \quad \cdot \quad \cdot \quad \cdot \quad \cdot \quad \cdot \quad$ C.1 
FIGURES

3.1 Spent Fuel Transportation Links Connecting Fuel Cycle Facilities

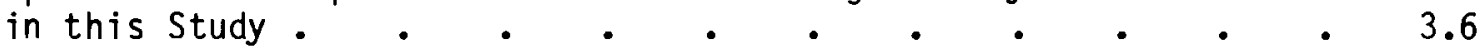

3.2 U.S. Divisions for Defining Average Shipping Distances $\quad$ • $\quad 3.7$

4.1 Structural Features of the NAC-1 Spent Fuel Cask . • • • 4.5

4.2 NAC-1 Sent Fuel Shipping Cask Cross Section . • . . . . 4.6

4.3 Structural Features of the IF-300 Spent Fuel Shipping Cask • . 4.9

4.4 IF-300 Spent Fuel Shipping System . . . . . . . . . 4.11

\section{TABLES}

2.1 Summary of Cask Requirements and Transportation Costs for the Four Spent Fuel Management Scenarios Developed for this Study - 2.3

3.1 Assumed Average Shipping Distances Used in this Study • • • 3.8

4.1 Current Spent Fuel Cask Characteristics and Fleet Sizes . 4.2

5.1 Average Rail Transit Speeds and Rail Security Costs • • • 5.5

5.2 Labor Requirements for Loading or Unloading the Reference Spent

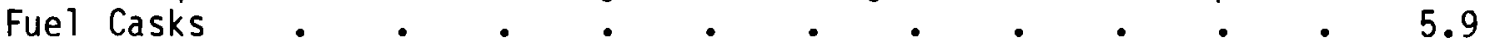

5.3 Summary of Unit Transportation Costs for Shipment of Spent Fuel in the Reference Truck Shipping System . • • • . 5.12

5.4 Summary of Unit Transportation Costs for Shipments of Spent Fuel

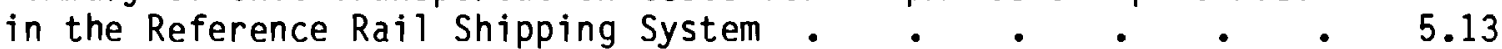

6.1 Near-Term Spent Fuel Transportation Hardware Requirements Reference Scenario/75\% Rail Shipping • • • • • • • 6.2

6.2 Near-Term Spent Fuel Transportation Hardware Requirements -
Consolidated Fuel Shipping Scenario/75\% Rail Shipping . . . 6.3

6.3 Near-Term Spent Fuel Transportation Hardware Requirements -
Delayed Reprocessing Scenario/75\% Rail Shipping • • • • • . 6.4

6.4 Near-Term Spent Fuel Transportation Hardware Requirements -

6.5 Annual Additional Cask Requirements and Capital Expenditures

6.6 Spent Fuel Transportation Costs for the Reference Spent Fuel
Management Scenario and Sensitivity Cases in this Study . $~$

6.7 Annual Transportation Costs Associated with the Proposed

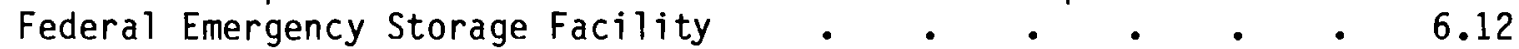


A.1 Summary of Annual Spent Fuel Receipt Rates for Destination Facilities - Reference, Consolidated Fuel and 50\% Truck

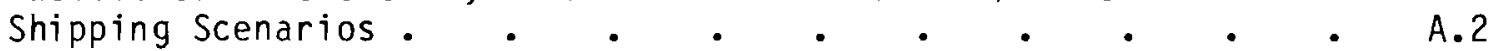

A.2 Summary of Annual Receipt Rates for Destination Facilities Delayed Reprocessing Scenario . . . . . . . A.3

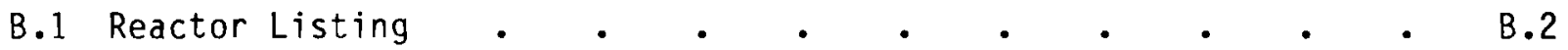

C. 1 Truck Freight Rates for Spent Fuel. . . . • • • . C.2

C.2 Rail General Freight Rates for Spent Fuel • • • • • • • C.5 


\subsection{INTRODUCTION}

Transportation of irradiated light water reactor (LWR) fuel is an integral part of the commercial nuclear fuel cycle. Shipments of spent fuel have been made commercially on a routine basis in the United States for many years. In the future, shipments of these materials are expected to increase substantially as chemical reprocessing plants and geologic isolation facilities become operational. Current technology appears adequate to assure the safe, reliable, and efficient transportation of spent nuclear fuel.

The objective of this study is to provide quantitative logistics and cost information for the transportation of commercial spent fuel associated with government emergency relief storage. Commercial reprocessing and disposal demonstration facilities compete for available casks so were also considered. Funding for this study was provided by the U.S. Department of Energy (DOE) Office of Spent Fuel Management and Reprocessing Systems and the Richland Operations Office through the Commercial Spent Fuel Management (CSFM) Program managed by Battelle, Pacific Northwest Laboratory (PNL). Results in this report include an assessment of the adequacy of current spent fuel transportation hardware fleet sizes to perform the needed transportation services and transportation cost estimates for an emergency storage facility. This information can be used by the DOE to encourage construction and operation of needed transportation hardware if the predicted future demand exceeds current capabilities. Cost information can be used to facilitate planning and evaluation of future spent fuel transportation systems, including transportation hardware.

Delays in the development of commercial reprocessing and/or spent fuel disposal facilities have resulted in nuclear utility companies retaining their spent fuel in on-site storage basins. Since many reactors were built at a time when commercial reprocessing was expected to be a viable business, utilities opted for small spent fuel storage basins (1-2 annual discharges plus full core reserve) because they assumed they could ship their spent fuel to a fuel reprocessing plant (FRP). Since commercial reprocessing has been delayed for more than a decade, many utilities are being faced with the possibility of shutdown due to a lack of adequate spent fuel storage capacity. The U.S. 
Congress is currently considering legislation that would require the DOE to provide a temporary, interim storage facility for emergency relief storage of spent fuel to prevent the shutdown of affected nuclear power plants.

The remainder of this report is divided into six sections. A summary of the results obtained in this study is given in Section 2.0. Future spent fuel transportation system scenarios and their mathematical computer models are discussed in Section 3.0. Section 4.0 contains descriptions of the current spent fuel cask fleet and the reference truck and rail casks selected for use in this analysis. Transportation unit costs (dollars per shipment) are developed in Section 5.0. Results of the spent fuel transportation logistics and cost studies are presented in Section 6.0. Conclusions and recommendations. for further work are discussed in Section 7.0 . 


\subsection{SUMMARY}

This report presents descriptions of potential future commercial spent fuel management systems and a quantitative analysis of transportation hardware and cost requirements for transport of commercial spent fuel in the commercial nuclear fuel cycle. Also presented is an assessment of the adequacy of the current U.S. spent fuel shipping cask fleet size to provide the needed transportation services. The potential future spent fuel management system is developed using Commercial Spent Fuel Management Program (CSFMP) guidelines and is cognizant of nuclear waste legislation currently under consideration by the U.S. Congress. Spent fuel transportation hardware requirements and cost information is developed using a computer modeling technique. The model developed for this study is interfaced with the CSFMP spent fuel data base.

The total spent fuel management system was considered in this study to quantify competition for transportation services. This study was based on the following assumptions: a system for Federal Interim Storage of spent fuel, a disposal demonstration at a Test and Evaluation facility (TEF), and a fuel reprocessing plant (FRP). Transportation services will also be needed for the spent fuel in storage at the Western New York Nuclear Service Center (West Valley) and the damaged core at the Three Mile Island (TMI) nuclear power station and these requirements were included in the study. In addition, some nuclear utility companies are planning to transship spent fuel from a storage basin approaching its maximum storage capacity to a less-full storage basin. Only planned transshipments within a utility system or to the Morris, Illinois storage facility (DOE 1982) are considered in this study.

Four commercial spent fuel management scenarios are developed and investigated in this study. The reference scenario provides for a 1984 opening date of the interim storage facility to receive spent fuel from the following facilities; LWRs that lose FCR capability, West Valley, and the damaged reactor core from TMI. The TEF is assumed to receive spent fuel beginning in 1987 . A FRP (assumed to be the Barnwell Nuclear Fuels Plant) is assumed to begin receiving fuel in 1987 in preparation for start-up in 1989. After this date, all commercial reactors, the Federal interim storage facility, and the TEF (begins retrieval and shipping out operations in 1993) are assumed to ship their spent fuel to the FRP (up to $1500 \mathrm{MTU} / \mathrm{yr}$ design capacity). 
Three alternatives to the reference scenario were developed and investigated to establish a range of transportation service demands. The first alternative represents shipping only consolidated fuel (disassembled fuel elements that have fuel rods only placed in canisters). In this case, shipping cask capacities are assumed to increase by a factor of two. This case could also represent the introduction of a new generation of shipping casks that are designed to transport long-cooled spent fuel (at least five years after reactor discharge). Only the costs and logistics for consolidated fuel shipping are considered. Engineering aspects of this alternative are beyond the scope of this study. The opening dates of all of the facilities are identical to the reference scenario. The second alternative scenario investigates the impact of delaying the opening date of the FRP until 1989. This increases substantially the amount of spent fuel transported to and stored within the Federal interim storage facility. The third alternative scenario in this study examines the effects of increasing the fraction of spent fuel shipped by truck from $25 \%$ in the reference scenario to $50 \%$.

Annual spent fuel transportation hardware requirements and transportation costs resulting from this study are shown in Table 2.1. The Table also includes information pertaining to the planned spent fuel transshipments DOE 1982). Transshipments are the only spent fuel movements planned for the years 1982 and 1983 on Table 2.1. Subsequent transshipments are planned for succeeding years but are all on-site transfers and do not significantly impact the cask requirements for those years.

Cask requirements for the reference spent fuel management scenario (FRP opens in $1987,25 \%$ truck shipping fraction) are 29 truck and 22 rail shipping systems. If fuel is assumed to be consolidated prior to shipment, the cask requirements are roughly one-half of the reference scenario requirements. The maximum annual cask requirements for the delayed reprocessing scenario are essentially identical to those for the reference scenario; however, there is a two year delay before this large number of casks is required. This is due to the delay in the opening date of the FRP. For the scenario where $50 \%$ of the 
TABLE 2.1. Summary of Cask Requirements and Transportation Costs for the Four Spent Fuel Management Scenarios Developed for this Study

\begin{tabular}{|c|c|c|c|}
\hline & & $\begin{array}{l}\text { Ref } \\
\text { Cask Requi }\end{array}$ & $\begin{array}{l}\text { rence Sce } \\
\text { ements (a) }\end{array}$ \\
\hline & Year & Truck & Rail \\
\hline & 1982 & 0 & 1 \\
\hline & 1983 & 1 & 3 \\
\hline & 1984 & 2 & 3 \\
\hline & 1985 & 1 & 2 \\
\hline & 1986 & 4 & 1 \\
\hline & 1987 & 29 & 18 \\
\hline & 1988 & 28 & 20 \\
\hline & 1989 & 28 & 18 \\
\hline & 1990 & 28 & 19 \\
\hline & 1991 & 27 & 19 \\
\hline & 1992 & 27 & 17 \\
\hline & 1993 & 27 & 20 \\
\hline & 1994 & 26 & 21 \\
\hline & 1995 & 29 & 22 \\
\hline
\end{tabular}

\section{rio.}

Transportation costs, (b)

$(M \$ / y r)$

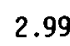

4.97

4.60

2.56

4.89

58.08

59.45

57.15

58.03

58.08

56.99

59.04

60.03

64.18
Consolidated Fuel Scenario

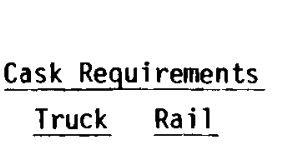

Transpor-

tation

Costs

Truck Rail

$M \$ / y r)$

2.49

2.30

1.28

2.44

29.04

29.73

28.57

29.02

29.04

28.49

29.52

30.02

32.09
Delayed Reprocessing Scenario

$\frac{\text { Cask Requirements }}{\text { Truck Rail }}$

Transpor-

tation

Truck Rail

$(M \$ / y r)$

2.99

4.97

4.60

2.56

4.89

9.66

13.41

55.94

57.52

57.49

56.92

58.96

60.02

64.18
50\% Truck Shipping Scenario

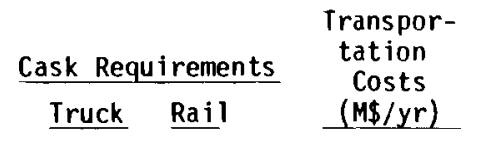

2.99

4.97

4.41

2.46

4.84

57.71

58.91

56.82

57.65

57.65

56.66

58.28

59.26

63.15

NOTE: For comparison purposes, the current spent fue 1 cask fleet contains approximately 22 reference truck-caskequivalents (including overweight truck systems) and 6 reference rail-cask eauivalents (including the uncompleted IL $10 / 24$ systems).

(a) Numbers in these columns represent the number of truck cask systems (capacity of 1 PWR or 2 BWR fuel elements) and rail

cask systems (capacity of 7 PWR or 18 BWR elements) required to transport the amount of fuel specified for each scenario.

(b) Transportation costs shown are the combined costs for truck and rail shipping in mid-1982 dollars. Transportation costs
not include capital costs for construction of new cask systems. Numbers contain excess significant fiqures for consistency. 
spent fuel is shipped in truck casks, 39 truck casks and 15 rail casks are required. A significant capital expenditure savings for spent fuel casks could be realized by increasing the amount of fuel shipped by truck.

Shipments of spent fuel to an FRP is the greatest demand on the transportation hardware in this study. When this facility opens, cask requirements and transportation costs reach a steady-state for subsequent years. The average transportation costs (costs incurred by the shipper, including handling costs) over these years are approximately $\$ 59 M / y r$ for the reference scenario; $\$ 30 \mathrm{M} / \mathrm{yr}$ for the consolidated fuel scenario, $\$ 58.5 \mathrm{M} / \mathrm{yr}$ for the $50 \%$ truck shipping scenario, and $\$ 59 M / y r$ for the delayed reprocessing scenario. This represents about a 50\% decrease in transportation costs for the consolidated fuel scenario and a small reduction in costs for the $50 \%$ truck shipping scenario.

The current cask fleet size was determined by telephone contacts with cask suppliers. Approximately 22 reference truck-cask-equivalents (counts each of the TN-8 and TN-9 overweight truck casks as three reference truck-caskequivalents) and 6 reference rail-cask-equivalents (counts the NLI-10/24 as 1.5 reference rail-cask-equivalents) are available. These values were compared with the near-term (up until 1995) cask requirements determined in this study. In general, the current cask fleet size is adequate until the FRP begins to receive fuel (1987 for the reference, consolidated fuel and 50\% truck shipping scenarios, and 1989 for the delayed reprocessing scenario). It was found that 7 additional truck cask systems and 16 additional rail cask systems are required to be in service before the FRP opens for the reference scenario. Seven more truck casks and 17 more rail casks are required for the delayed reprocessing scenario. For the consolidated fuel scenario, five additional rail casks are required and the current truck cask fleet is adequate until at least 1995. If the shipping fraction is changed to $50 \%$ truck and $50 \%$ rai1, 17 additional truck casks and 9 additional rail casks are required prior to the FRP opening date. As expected, capital expenditures for additional casks are minimum for the consolidated fuel scenario. Next largest is the $50 \%$ truck shipping scenario. The highest capital expenditures are for the reference and delayed reprocessing scenarios. These results are valid only for the given set of assumptions. 
It is recommended, based on the results of this study, that licensing of existing spent fuel casks for transport of consolidated fuel be pursued if the additional fuel handling costs do not affect transportation savings. It is shown that spent fuel transportation hardware requirements and costs can be reduced by about a factor of 2 for consolidated fuel shipping due to increased shipping cask capacities. Cask capacities for future spent fuel transportation purposes could also be increased by a separate factor of about two by designing a new generation of casks to transport long-cooled fuel, using current bases for cask handling and occupational exposures. Either of these two alternatives, consolidating the fuel or designing new casks, is able to substantially reduce the costs associated with spent fuel transportation.

It is recommended that further studies be undertaken to refine cost estimates of transporting and handling spent fuel. This study should include an assessment of the costs associated with consolidating fuel at reactors or at centralized fuel consolidation facilities, including equipment, construction, and operating costs. Other studies recognized by this analysis which may be of use to utility companies include a detailed economic assessment of legal-weight truck shipments versus over-weight truck shipments and an analysis of the advantages and disadvantages of shipping fuel in dual-purpose storage and transportation casks. 



\subsection{COMMERCIAL SPENT FUEL TRANSPORTATION NETWORK MODEL}

This section provides the bases and assumptions required to define the future LWR spent fuel transportation system. Included are assumptions pertaining to a proposed system for Federal Interim Storage for nuclear utility spent fuel, a fuel reprocessing plant (FRP), a disposal repository Test and Evaluation Facility (TEF), the disposition of the damaged core at the Three Mile Island (TMI) Nuclear Station, and removal of spent fuel from the Western New York Nuclear Service Center (West Valley). All of the above facilities will eventually require spent fuel transportation services and will receive spent fuel from commercial LWRs (except TMI and West Valley which will ship fuel). These assumptions are used to define the baseline spent fuel transportation network connecting the facilities. Also defined in this section are the shipping distances between commercial LWRs and the facilities listed above, bases and assumptions for transportation cost calculations, spent fuel storage requirements, and reference truck and rail spent fuel shipping systems for this study. In addition, the computer model developed at PNL to examine the spent fuel cask fleet requirements and transportation costs is described in this section.

\subsection{SPENT FUEL MANAGEMENT SCENARIOS AND STUDY BASES}

A number of alternatives are currently being considered for management of spent nuclear fuel from commercial LWRs. Transportation demands and, therefore, logistics and costs are unique to each alternative. Final decisions on spent fuel management strategies are not expected for some time, although nuclear waste bills are currently being debated by the U.S. Congress. Several spent fuel management scenarios were developed utilizing CSFM Program guidelines and the nuclear waste legislation to include changes in future waste transportaton system demands. The reference spent fuel management scenario and appropriate sensitivity cases are discussed in the following sub-sections. Further information concerning the amounts of spent fuel to be shipped in the near-future is discussed in Appendix A. 


\subsubsection{Reference Spent Fuel Management Scenario}

Commercial spent fuel is currently stored in water basins at power reactor sites. The capacities of several reactor storage basins are rapidly being reached. Nuclear electric utility companies are at this time attempting to increase their spent fuel storage capabilities through several means including: 1) pool expansion, 2) reracking, including use of high density neutron poison racks, 3) on-site transfer to a less-full storage basin that serves a separate LWR and 4) discharging fuel from the reactor core less frequently. Utility companies wish to maintain full core reserve (FCR) in their storage basins which is the storage capacity for discharging the entire reactor core. If utilities with reactors with near-term storage problems decide not to maintain $F C R$, they delay their need for interim storage. However, utilities will pay a significant economic penalty if $F C R$ is required for reactor pressure vessel inspection or other maintenance activities and the storage space is not available. Thus, there is considerable incentive to maintain FCR. Alternatives to losing $F C R$, if all other on-site storage options are exhausted, include shipping spent fuel to Federal interim storage or shutting down electrical production. Obviously, the former alternative is considered preferable. Shipping spent fuel to Federal interim storage is a major demand on the spent fuel transportation hardware fleet considered in this study.

Federal interim storage in this study is assumed to begin receiving commercial spent fuel in 1984. Only reactors that have reached maximum on-site storage capacity (maintaining $F C R$ ) will be allowed to ship their spent fuel. Only the amount of fuel in excess of $F C R$ discarge capability will be shipped to emergency storage, i.e., utilities will not be allowed to empty their storage basins into Federal interim storage. The maximum capacity of Federal storage differs in the House and Senate versions of the nuclear waste bills (H. R. 7187 and S. 1662, respectively) although, neither of the proposed capabilities are expected to be reached according to the spent fuel storage projections made by DOE (1982). A final assumption concerning interim storage relates to the transfer of fuel. It is assumed that fuel transfer operations will begin in 1987 and be completed by 1991. No spent fuel will be shipped to the Federal interim storage facility after 1987 in the reference scenario. Fuel that was in interim storage is assumed to be shipped to a Fuel Reprocessing Plant (FRP) 
which is expected to be opened in 1987 (see below). All commercial LWRs, including those with no near-term storage problems, are also assumed to begin shipping spent fuel to the FRP in 1987.

At this time, no commercial fuel reprocessing activities are occurring. However, the ban on reprocessing has been revoked opening the way for these operations to occur. It will be assumed in this study that a commercial FRP, the Barnwell Nuclear Fuels Plant (BNFP), will begin receiving fuel in 1987 in preparation for a 1989 start-up of reprocessing operations. BNFP has the capability to reprocess spent fuel containing up to 1500 MTU annually. It is assumed that all spent fuel will be shipped to BNFP for reprocessing, i.e., spent fuel will not be disposed of as waste. An additional fuel reprocessing facility is expected to be operational around the year 2000 . However, this study is primarily interested in evaluating near-term transportation requirements and the second FRP was not included in the reference scenario.

BNFP is assumed to receive spent fuel from several sources. These include fuel discharged from LWRs in excess of their maximum storage capacity (maintaining FCR) and from Federal interim storage (assumed to be emptied of spent fuel in a levelized manner by the year 1991). In addition, a Test and Evaluation Facility (TEF) is assumed to ship the spent fuel to BNFP (see below). The last sources of spent fuel for BNFP are commercial LWRs that do not currently have on-site storage problems. Spent fuel from these LWRs is assumed to be shipped in quantities that will make up the balance of the 1500 MTU/yr reprocessing capacity.

Current nuclear waste legislation contains provisions for a Test and Evaluation Facility (TEF). This facility is intended to demonstrate the feasibility and safety of disposal of spent fuel and radioactive wastes in deep geologic repositories. During the period 1987 - 1993, up to 300 waste packages will be emplaced in the TEF. It will be assumed that the facility for packaging of the waste form (in preparation for geologic disposal) will be collocated with the TEF. Therefore, the spent fuel shipping systems need not be used for transfer of the packaged spent fuel between the packaging facility and the TEF. The source of spent fuel for the TEF is assumed to be an unspecified LWR $4000 \mathrm{~km}$ (2500 $\mathrm{mi}$.) away from the TEF location, assumed to be 
somewhere in the western U.S. The TEF is assumed to complete its demonstration activities by 1993 and the spent fuel packages are assumed to be retrieved, removed from the burial package, and shipped to BNFP for reprocessing. Retrieval and transfer operations are assumed to be completed by 1995 .

Another potential source of commercial spent fuel may be the storage pool at the former Nuclear Fuels Services, Inc. (NFS) reprocessing plant at West Valley, New York (DOE 1982). The state of New York has ordered that all of the spent fuel in the storage pool must be removed off-site. For this study, it is assumed that this spent fuel (about 169 MTU) will be shipped to Federal interim storage beginning in 1984. All of the fuel is assumed to be transferred to interim storage in a levelized manner by 1987 . This spent fuel is assumed to be shipped to BNFP by the year 1991 in the same manner as the fuel stored temporarily for utility companies.

The final source of spent fuel considered in this study is the Three Mile Island (TMI) Unit II Nuclear Reactor. Shipment of the damaged TMI core was initially evaluated for the DOE by Allied-General Nuclear Services (AGNS 1980). Approximately 200 spent fuel assemblies or spent fuel debris canisters may be produced by operations to remove the damaged core. These are assumed to be shipped to Federal interim storage beginning in 1984 , although it is possible shipments will not begin until the late 1980's. Shipments are assumed to be made in a levelized manner to complete the transfer of the entire core off-site by the end of 1986 .

A further demand for spent fuel transportation services is transshipment of fuel. Transshipment is the transfer of spent fuel from a power reactor storage basin to a less-full storage basin at another reactor or to the Morris, Illinois, storage facility. Due to legal and licensing difficulties, only transshipment within a utility system is considered practical. The planned utility transshipments are presented in document DOE/RL-82-1 (DOE 1982). Only the shipments planned to take place prior to 1987 are included in the logistics and costs information developed in this report. In addition, one utility company planning to transship fuel already owns shipping casks. The planned transfer is entirely within their site boundaries. Thus, this will not require the transportation services considered in this study. 
This section has served to indicate the reference nuclear spent fuel management scenario considered in this study. The reference scenario defines the transportation links connecting the facilities of most concern to the CSFM program. This information is summarized in Figure 3.1. This figure shows the facilities under consideration in this study, their planned operational dates, and the transportation links connecting them.

The spent fuel transportation network must be further defined in order to construct logistics and cost models. Important parameters include the transportation distances between the fuel cycle facilities under consideration. For this study, the U.S. is assumed to be divided into 5 regions shown in Figure 3.2 to define shipping distances. Average shipping distances to Federal storage, TEF, or BNFP were assigned to all LWR's in a particular region. For example, all LWRs in Region 1 (western U.S.) are assumed to have an average shipping distance to BNFP of $4000 \mathrm{~km}$ (2500 mi.). The average shipping distances between the facilities in this study are shown in Table 3.1. It is felt that these distances are conservative estimates based on the locations of commercial reactors, BNFP, the proposed Federal interim spent fuel storage site, and the TEF. It is assumed that the proposed Federal interim storage site is located in the eastern U.S. (nearest to most of the operating LWRs) and the proposed TEF is located in the western U.S. (most site exploration work is in the western region). These data are also based on information contained in Shirley et al. (1981) and a recently published report (Cole 1982).

Spent fuel is assumed to be transported in either truck or rail shipping systems, i.e., water transport of spent fuel is not considered in this study. Reference truck and rail shipping systems were selected to define and standardize important shipping parameters, such as empty and loaded weights and shipment capacities (see Section 4.0). It is assumed for the reference scenario in this study that LWRs will ship 25\% of their fuel (by weight) in truck systems and $75 \%$ in rail systems. This applies only to LWRs that are equipped with rail sidings. Reactors with no rail sidings are assumed to ship all of their spent fuel by truck. Federal interim storage, the TEF, and BNFP are assumed to have adequate provisions for receiving and/or shipping $25 \%$ by 
FIGURE 3.1. Spent Fuel Transportation Links Connecting Fuel Cycle Facilities in this Study - Reference Scenario

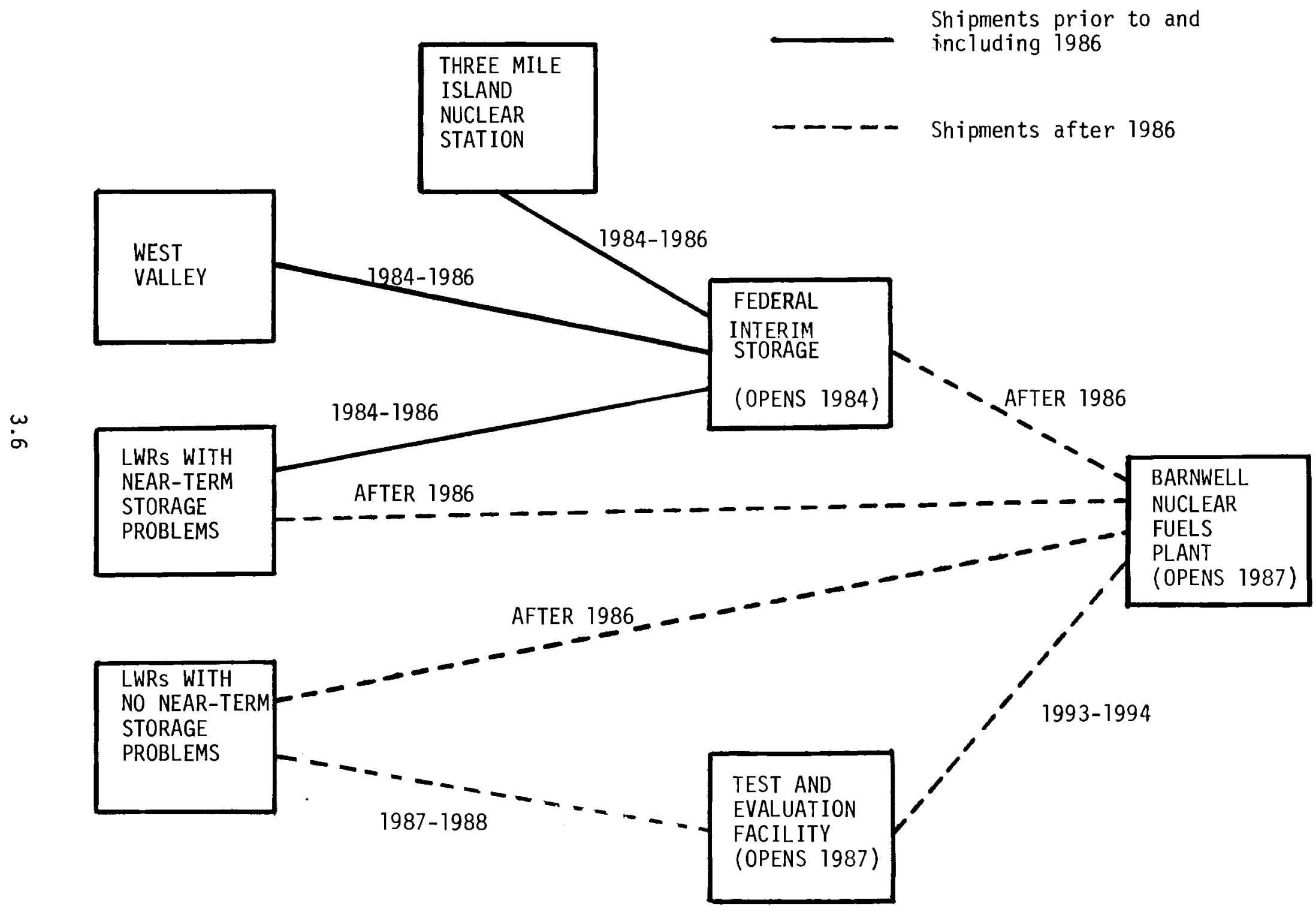




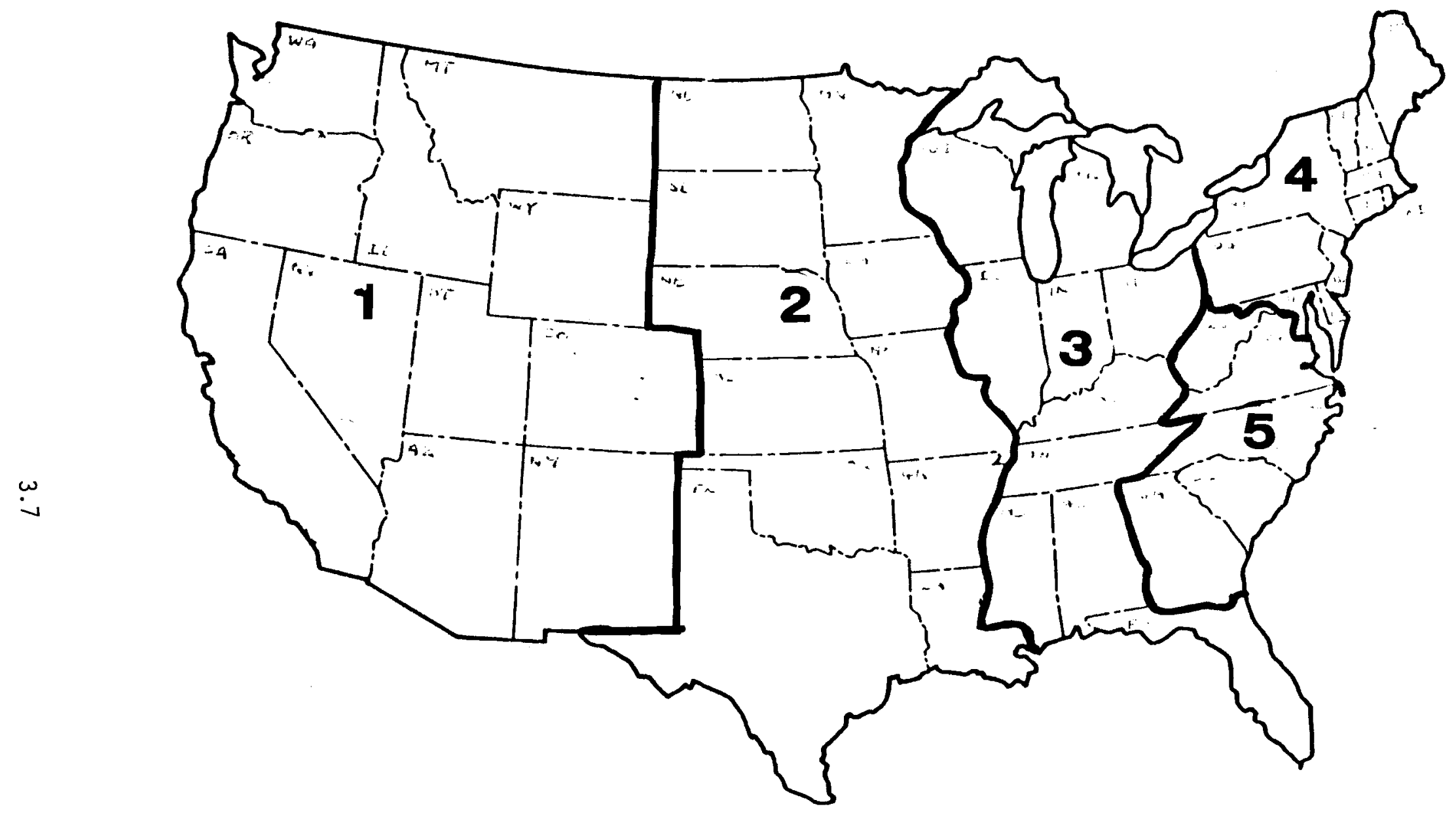

FIGURE 3.2. U.S. Divisions for Defining Average Shipping Distances 
truck and $75 \%$ by rai1. BNFP currently does not have adequate truck receiving facilities but modifications to include more truck docking space may be made in the future. Further details concerning the shipping mode split are discussed in Section 3.2 .

TABLE 3.1. Assumed Average Shipping Distances Used in this Study

\begin{tabular}{l|c|c|c|}
\cline { 2 - 4 } & $\begin{array}{c}\text { FEDERAL } \\
\text { INTERIM } \\
\text { STORAGE }\end{array}$ & TEF & BNFP \\
\hline Region 1 & $4000(2500)$ & $800(500)$ & $4000(2500)$ \\
Region 2 & $2400(1500)$ & $2400(1500)$ & $2400(1500)$ \\
Region 3 & $1600(1000)$ & $3200(2000)$ & $1600(1000)$ \\
Region 4 & $1200(750)$ & $4000(2500)$ & $1600(1000)$ \\
Region 5 & $800(500)$ & $4000(2500)$ & $800(500)$ \\
Federal Emergency & -- & $3200(2000)$ & $1200(750)$ \\
Storage Faci1ity & $3200(2000)$ & -- & $4000(2500)$ \\
TEF & $1200(750)$ & $4000(2500)$ & --
\end{tabular}

The reference truck shipping system in this study is a legal-weight truck (LWT) system, i.e., gross vehicle weight (tractor, trailer, shipping container, cargo, and ancillary equipment) does not exceed 36.3 MT (80,000 lbs.). It is recognized that over-weight truck (OWT) systems may be more economical due to increased payload capacities. However, in order to calculate the costs of transporting spent fuel in OWT systems, specific routes must be defined and over-weight penalties for each state on the route must be calculated (penalties differ between states). Furthermore, the use of OWT shipments on a routine basis (if this is allowed in the future) would require considerable administrative effort to obtain repeatedly the special permits from the states involved. 
The key assumption used when calculating transportation costs is that transportation services will be supplied by private industry as a commercial venture. The costs reported are in mid-1982 dollars and include operating costs plus amortization of transportation hardware plus profits, at commercial rates. Thus, transportation costs are calculated according to the following formula:

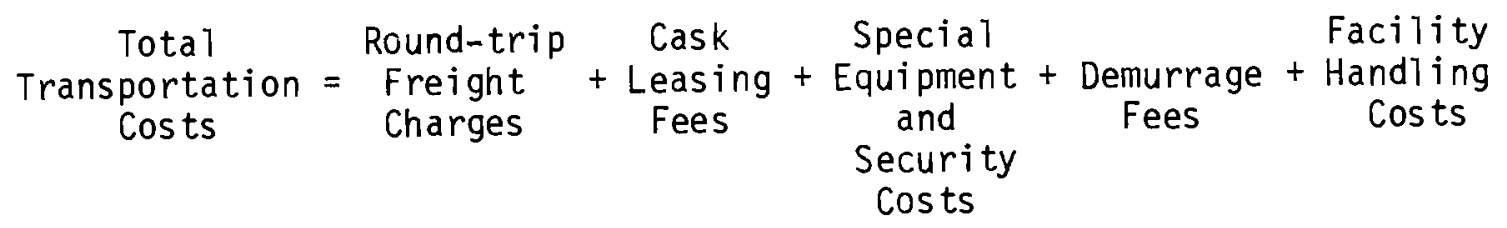

The factors in the above equation are discussed in greater detail in Section 5.0.

\subsubsection{Sensitivity Cases}

Sensitivity cases are analyzed to determine the impacts on the reference scenario of alternative spent fuel management strategies. Three alternatives are considered in this study: 1) shipping only consolidated spent fuel 2) delaying the opening date of the FRP until 1989, and 3) changing the shipping mode split to $50 \%$ truck and $50 \%$ rail. These three alternative scenarios are described in this section.

The first sensitivity case considered in this study examines the impacts of shipping consolidated spent fuel in currently licensed shipping systems. The planned opening dates for the facilities are assumed to be identical to the reference scenario. Fuel consolidation consists of cutting and disassembly of spent fuel elements and placing fuel rods only into monolithic steel canisters. The remaining fuel assembly skeleton (end plates, spacers, etc.) is removed, compacted, placed in canisters, and disposed of as non-transuranic waste. Uncertainties still exist in the criticality and thermal analyses for storage and transportation purposes, but it is believed that shipping and storing consolidated fuel is practical. This study only considers the logistics and costs associated with shipping consolidated fuel. Engineering limitations, such as impacts of the extra weight on cask strength, shielding considerations, and crane lifting capacities, are beyond the scope of this analysis. 
The primary advantage of fuel consolidation can be visualized by recognizing that the cross-sectional area occupied by fuel rods in an intact fuel assembly ranges between 38 and 44 percent of the cross-sectional area of various LWR fuel asemblies (DOE 1981). For this study, it is assumed that the fuel rods will be placed in canisters with the identical dimensions of the unconsolidated fuel element, i.e., the canisters for consolidated BWR and PWR fuel occupy the same envelope as the unconsolidated BWR and PWR fuel elements, respectively. However, the consolidated fuel canisters will accept the number of fuel rods normally contained in two fuel elements. Therefore, the capacities of the reference truck and rail shipping casks are assumed to double when transporting consolidated fuel. Fuel consolidation operations are assumed to occur in reactor storage pools. The costs associated with fuel consolidation are not considered in this study.

The sensitivity case for shipping only consolidated fuel is essentially identical to a case where a new generation of spent fuel shipping systems is introduced. Future spent fuel casks will most likely be designed to transport longer-cooled fuel (at least 5 years after reactor discharge) as opposed to the current generation of casks that are designed to transport short-cooled fuel (about 120 days after discharge). The need for this type of cask can be illustrated by recognizing that the average age of the fuel that is expected to be reprocessed at BNFP is about 16 years after discharge (Carr 1982). This results in significantly lower heat dissipation and shielding requirements for future cask designs. Capacities of the future truck and rail spent fuel casks can be up to twice the capacity of the currently licensed casks with present handling and radiation control practices. This is similar to consolidated fuel shipment capacities. However, increasing the cask capacities by reducing the amount of shielding on the cask could increase occupational exposures. This trade-off may necessitate new cask-handling techniques and equipment that are designed to reduce occupational exposures to personnel. It is not known at this time if this will significantly change the current cask handling characteristics. These engineering analyses of new casks are beyond the scope of this study. 
The second sensitivity case is a scenario where the opening date of BNFP is delayed until 1989. This will significantly increase the amount of spent fuel destined for Federal interim storage. For the delayed reprocessing scenario, a total of approximately 500 MTU of spent fuel will be shipped to Federal interim storage. This compares to about 90 MTU shipped to Federal interim storage in the reference scenario (DOE 1982). The impacts on the spent fuel transportation hardware requirements and on transportation costs for delaying the startup of reprocessing operations are evaluated.

The last sensitivity case considered in this study investigates the impacts of increasing the amount of spent fuel shipped by truck. It is not clear at this time which mode, truck or rail, will be used most extensively in the future. Rail systems have the advantage of about 7 times the payload capacity of truck systems. However, truck systems are able to travel much faster average speeds than rail systems. The trend is toward more truck shipping. In fact, something over $90 \%$ of the U.S. commercial spent fuel that has been moved has been transported in truck casks (NAC 1981). To determine if there are significant impacts on spent fuel transportation hardware requirements or transportation costs, the reference shipping mode split will be changed to $50 \%$ rail and $50 \%$ truck for this sensitivity case. The opening dates of the facilities are the same as the reference scenario for comparison purposes.

\subsection{SPENT FUEL TRANSPORTATION SYSTEM MODEL}

PNL has developed a spent fuel transportation system model to support calculations in this study. This model represents the transportation of spent fuel from commercial power reactors and the West valley storage pool to interim storage facilities and/or to final destination facilities. The spent fuel origin and destination facilities were described in detail in previous sections. This section describes the spent fuel transportation system model developed for this study. The model has two primary functions; the first is to calculate shipping schedules and transportation hardware requirements and the second is to calculate transportation costs.

The transportation system model contains provisions so that spent fuel may be shipped either by rail or by truck with separate accounting for the two 
modes. The shipments may be a single shipment leg from reactor to final destination (reprocessing plant, TEF, or FES) or two shipment legs from reactor to an interim storage sites and later to the final destination. Two distinct interim storage facilities are allowed and up to four final destination facilities are allowed. The roles of the various facilities are described later. The transportation system was illustrated previously in Figure 3.1 . Input requirements for the model are described in Appendix $B$.

The model is interfaced with the Commercial Spent Fuel Management Program's spent fuel data base. This data base contains information for all operating or planned commercial nuclear reactors and other existing storage facilities. The "maximum at-reactor" storage case shown in the document describing this data base (DOE 1982) is used as the reference case in this study to determine the utility spent fuel storage and transportation requirements. The information required by the model for each reactor includes present spent fuel inventory, present and future water basin capacities, and a projection of future spent fuel discharges. This information serves as the transportation source term in the model. Other information required by the model includes descriptions of transportation equipment, average truck and rail shipment speeds, descriptions of shipping/receiving facilities, and transportation unit costs. Examples of this type of information include shipping cask capacities, annual spent fuel handling capacities at terminal facilities, and fractions of spent fuel shipped by truck or rail.

The model represents transportation of spent fuel to two interim storage sites represented by the Test and Evaluation Facility (TEF) and Federal interim storage. The TEF is assumed to receive or ship only by truck and Federal interim storage can receive either by rail or truck. All shipments from Federal interim storage are assumed to be rail shipments for this study. Some reactors do not have rail sidings so all spent fuel from those reactors must be shipped by truck. It is assumed that the spent fuel from reactors that do have rail sidings will be shiped by either rail or truck in proportions defined by input variable RFR (see Appendix B), the fraction that is assumed to be shipped by rail. RFR can be changed by the user to any value less than 1 . The truck shipping fraction is 1 minus the rail fraction. 
The spent fuel logistics are determined sequentially by the following four steps. The first three are site specific but the fourth step is calculated by region and is not reactor-specific. The four steps are 1 isted below and are discussed in the following paragraphs.

1. Specified shipments from specific reactor to TEF or Federal interim storage.

2. Shipments required to maintain full core reserve at each reactor.

3. Shipments to remove the inventory from the TEF and Federal interim storage.

4. Shipments to make up the balance of the design receiving rate at the final destination facility.

The user may explicitly specify the number of assemblies shipped from specific reactors to the TEF or Federal interim storage. The shipments to Federal interim storage are specified by the user so that shipments from the West Valley storage pool and TMI can be incorporated. The specifications are input in arrays IRSH and NASH (see Appendix B).

After calculating the specified shipments, the model calculates the number of assemblies that need to be shipped from each reactor each year so that full core reserve is maintained. Such requirements will be either shipped to Federal interim storage, or shipped to the final destination depending on what facilities are receiving fuel in that year. The shipments are made to the final destination facility if it is receiving spent fuel. If the final destination facility is not yet operating, but Federal interim storage is operating, the shipment is made there. No shipments can be made before the facilities are operating.

Next, the model calculates the shipments required to remove the spent fuel inventories from the TEF (truck only) and from Federal interim storage (rail only). These shipments go to the final destination facility. The annual removal rate is specified in input array FREM (see Appendix $B$ ) and is given as a fraction of the total receipts at the interim storage facilities that will be shipped each year.

Finally, the remaining shipments to fulfill the specified receiving rate at the final destination facility are calculated on a regional basis, rather 
than a reactor specific basis (see figure 3.2 ). The number of assemblies of each type (BWR or PWR) by each transit mode (rail or truck) from each region received at the FRP in a given year is assumed to be proportional to the total amount of fuel available in that region. This availability is the cumulative regional discharges minus specified shipments and shipments to maintain full core reserve requirements, both projected over the entire study period, and minus regionally determined shipments during previous years. The final destination's spent fuel receving rate is input in array NASREC (see Appendix B).

After the number of shipments are calculated, the model calculates the transportation cask requirements. Since the bulk of the shipments will be determined on the regional basis rather than individual reactors, all assumed distances are based on regional average transit distance rather than specific reactor locations. The time required to complete each shipment is based on average distance from reactors in a region to destination facilities as shown in Table 3.1 (input array DIST, see Appendix B), average speed (input array SPEED, see Appendix $B$ ), and the time to load and unload the cask (input array $T T$, see Appendix B). The cask requirements are thus based on the calculated number of shipments, the calculated time to complete each shipment, and the average cask utilization fraction (input variable CUSE).

The shipping schedule (in shipments per year for each origin-destination combination), the number of cask days required to transport the appropriate quantities of spent fuel, and the annual cask requirements are calculated by the first functional component of the transportation system model. This is a major output of the model. The shipping schedule is used to calculate transportation costs. The output format includes summaries of the numbers of shipments and casks (truck and rail are listed separately) required for each origin-destination combination in each year.

The total transportation costs include shipping charges, demurrage costs (costs assessed by transport company for non-travel. status), security costs, cask lease costs, and facility handling costs. Shipping charges are based on numbers of shipments and shipment freight cost (input array SHCOST, see Appendix B). Demurrage cost is based on the average time to load and unload each cask (input array TT) and the daily demurrage rate (input array DEM). The security cost is based on a security charge assessed per mile of shipping 
distance (input array SECCSM), a charge per day (input array SECCSD), the distance by region (input array DIST) and the daily travel speed (input array SPEED). Cask lease costs are based on a daily lease rate (input array CASK), the number of shipments, and the calculated time to complete a shipment. Handling costs are based on a daily charge and the time to complete handling operatins (input arrays HAND and TT). Transportation cost parameters and unit costs are described in more detail in section 5.0 .

The output from the cost section of the model includes the total transportation costs as well as a summary of the charges for each of the four transportation cost elements described in section 5.0. These costs are also divided into each origin-destination combination considered in this study so costs incurred by each region and facility in each year can be seen. 
$\cdot$
$\therefore$
$\therefore$ 


\subsection{LWR SPENT FUEL SHIPPING SYSTEMS}

This section provides detailed information on the current spent fuel shipping cask fleet and descriptions of the reference truck and rail casks used in this study. The current cask fleet size discussed in the following section will be assessed to determine its adequacy to satisfy near-term spent fuel transportation needs. The next two sections contain descriptions of the reference truck and rail spent fuel shipping systems that will be used to define important shipping parameters used in the logistics and cost models. There was no intent to endorse or reject any particular shipping system. However, reference systems were selected to provide consistency within this study using state-of-the-art hardware.

\subsection{Current Spent Fuel Shipping Cask Fleet}

Spent fuel from commercial nuclear power reactors has been shipped in the United States for many years. Existing cask systems are massive, heavilyshielded, and designed to transport high-burnup and short-cooled fuel from current generation LWRs. Spent fuel that will be shipped in the future will most likely have cooled in reactor storage basins for significantly longer than the fuel the existing casks are designed to transport (i.e., a cooling period as short as 120 days after reactor discharge). Therefore, future cask systems may be designed to transport longer-cooled fuel, perhaps on the order of 5 years after reactor discharge. Casks designed for long-cooled fuel may have increased capacities due to reductions in shielding thicknesses and cooling requirements. However, existing casks will be used as reference shipping systems in this study to be conservative and because the shipping parameters (cask weights, capabilities, etc.) are not adequately defined for the conceptual systems.

The spent fuel shipping casks that are existing and have been licensed in the U.S. are shown in Table 4.1. Included in this table are two rail casks that are not currently licensed in the U.S. for fissile materials (NAC-3 and TN12). These casks are included for information purposes only. Cask characteristics are primarily extracted from Vigil and Allen (1982). The numbers of casks in existence in the U.S. Were obtained from telephone contacts with the cask supplier companies in June, 1982. Supplementary availability information on existing and licensed casks is as follows: 
TABLE 4.1. Current Spent Fuel Cask Characteristics and Fleet Sizes ${ }^{(a)}$

\begin{tabular}{|c|c|c|c|c|c|c|c|c|}
\hline \multirow[b]{2}{*}{$\begin{array}{c}\text { Cask } \\
\text { Designation } \\
\end{array}$} & \multirow[b]{2}{*}{$\begin{array}{l}\text { Current } \\
\text { Supplier(b) }\end{array}$} & \multirow[b]{2}{*}{$\begin{array}{c}\text { Primary } \\
\text { Transport } \\
\text { Mode } \\
\end{array}$} & \multicolumn{2}{|c|}{ Capacity } & \multirow{2}{*}{$\begin{array}{c}\text { Cask } \\
\text { Empty } \\
\text { Weight } \\
(\mathrm{kg}) \\
\end{array}$} & \multicolumn{2}{|c|}{ Cask Dimensions } & \multirow[b]{2}{*}{$\begin{array}{l}\text { Number of } \\
\text { Casks in } \\
\text { U.S. (c) }\end{array}$} \\
\hline & & & $\begin{array}{l}\text { Fuel Assemblies } \\
\text { PWR/BWR } \\
\end{array}$ & $\begin{array}{l}\text { Thermal } \\
\operatorname{limit} \\
(\mathrm{kw}) \\
\end{array}$ & & $\begin{array}{c}\text { External } \\
\text { (m) }\end{array}$ & $\begin{array}{c}\text { Internal } \\
\text { Cavity } \\
\text { (m) }\end{array}$ & \\
\hline$N A C-1$ & NAC & $L W T^{(d)}$ & $1 / 2$ & $\begin{array}{r}2.5 \text { Dry } \\
11.5 \text { Wet }\end{array}$ & 22,660 & $1.27 \mathrm{D} \times 5.13$ & $0.34 \mathrm{D} \times 4.52$ & 5 \\
\hline$N F S-4(e)$ & NAC & LWT & $1 / 2$ & 11.5 Wet & 22,660 & $1.270 \times 5.13$ & $0.34 D \times 4.52$ & 2 \\
\hline NLI I-1/2 & NAC & LWT & $1 / 2$ & 10.6 Dry & 19,770 & $1.200 \times 4.90$ & $0.34 \mathrm{D} \times 4.52$ & 5 \\
\hline NLI- $10 / 24(f)$ & NAC & Rail & $10 / 24$ & 70.0 Dry & 83,540 & $2.460 \times 5.18$ & $1.4 \mathrm{D} \times 4.56$ & 2 \\
\hline IF -300 & G.E. & Rail & $7 / 18$ & $\begin{array}{l}61.5 \text { Wet } \\
11.7 \text { Dry }\end{array}$ & 63,490 & $\begin{array}{l}1.910 \times 5.03 \mathrm{PWR} \\
1.910 \times 5.28 \mathrm{BWR}\end{array}$ & $\begin{array}{l}0.950 \times 4.25 \mathrm{PWR} \\
0.950 \times 4.57 \mathrm{BWR}\end{array}$ & 4 \\
\hline TN-8 & TN & $\mathrm{OWT}^{(g)}$ & 3 PWR & 35.5 & 33,000 & $1.70 \times 4.87$ & $\begin{array}{l}\text { 3 Square } \\
\text { Cavities } \times 4.28\end{array}$ & $0^{(\mathrm{h})}$ \\
\hline TN-9 & TN & OWT & 7 BWR & 24.4 & 32,500 & $1.670 \times 5.1$ & $\begin{array}{l}7 \text { Square } \\
\text { Cavities } \times 4.52\end{array}$ & 2 \\
\hline FSV -1 & G.A. & LWT & $6 \mathrm{HTGR}^{(i)}$ & 4.1 Dry & 20,860 & $0.790 \times 5.33$ & $0.420 \times 4.98$ & 3 \\
\hline$N A C-3 K^{(j)}$ & NAC & Rail & $12 / 32$ & 100.0 Wet & 85,710 & $2.34 \mathrm{D} \times 5.41$ & $1.220 \times 4.95$ & 0 \\
\hline$T N-12^{(j)}$ & TN & Rail & $12 / 32$ & 120.0 Dry & 82,990 & $2.500 \times 5.90$ & $1.220 \times 4.59$ & 0 \\
\hline $\begin{array}{l}\text { (a) Cask char } \\
\text { (b) Suppl ier } \\
\text { G.A. = Ge } \\
\text { (c) These dat } \\
\text { (d) LWT = leg } \\
\text { (e) NAC-1 and } \\
\text { (f) Internal } \\
\text { (g) OWT = ove } \\
\text { (h) Two TN-8 } \\
\text { (i) This cask } \\
\text { (j) The NAC-3 }\end{array}$ & $\begin{array}{l}\text { cteristics are } \\
\text { ompanies are } \\
\text { eral Atomic Co } \\
\text { were obta ined } \\
\text { l-weight truck } \\
\text { NFS-4 casks ar } \\
\text { askets for spe } \\
\text { weight truck } \\
\text { asks are expec } \\
\text { is used to shi } \\
\text { and TN-12 rai }\end{array}$ & $\begin{array}{l}\text { Vigil and } \\
\text { teviated as } f \\
\text { telephone c } \\
\text { the same } \\
\text { uel do not } \\
\text { to be deliv } \\
\text { gh temperat } \\
\text { isks are cur }\end{array}$ & $\begin{array}{l}\text { n ( } 1982) \text {. } \\
\text { s: NAC = Nucle } \\
\text { ts with cask st } \\
\text { ntly exist. } \\
\text { by December } 19 \\
\text { as cooled reac } \\
\text { y under develo }\end{array}$ & $\begin{array}{l}r \text { Assurance } \\
\text { plier compar } \\
\text { r (HTGR) fue } \\
\text { ent. }\end{array}$ & ments & eral Electric 0 & = Transnuclear & \\
\hline
\end{tabular}


Transnuclear Inc. (TN). TN is the only U.S. company fabricating spent fuel shipping casks at this time. Currently, there are two TN-9 casks (for BWR fuel) in the U.S. and one additional TN-9 on order. Of the two that are completed, one is owned by a utility company (Commonwealth Edison) and one is owned by TN. There are no TN-8 casks (for PWR fuel) in the U.S. at this time. However, two are currently being fabricated in France and TN expects both to be delivered to the U.S. by the end of December, 1982. Both TN-8 casks are currently owned by TN.

General Electric Co. (GE). GE supplies the IF-300 spent fuel rail cask. there are a total of four completed IF-300 casks in existence. Three are owned and operated by GE and the fourth is owned by a utility company (Carolina Power and Light). GE and $C P$ and $L$ have recently suspended use of the IF-300 cask for shipment of BWR spent fuel due to irregularities in the BWR internal baskets. The casks will not be used for BWR spent fuel shipments until compliance with NRC regulations has been demonstrated.

Nuclear Assurance Corp (NAC). NAC supplies the NAC-1 (NFS-4) ${ }^{(a)}$ and $\mathrm{NLI}-1 / 2$ truck casks, and the NLI-10/24 rail cask. National Lead Industries (NLI) manufactured five NLI-1/2 truck cask systems. NAC currently has a long term lease on all five of these casks (NLI is out of the spent fuel shipping business at this time). Two complete NLI-10/24 rail casks have been fabricated (including rail cars) and NAC holds leases on both of them. A third is $20 \%$ to $30 \%$ complete on a railcar and nine more are in various stages of completion without railcars; all are leased to NAC. The internal spent fuel baskets for the two completed NLI-10/24 casks have been removed and melted so NLI could recover the silver contained therein. These two casks cannot be used until new baskets are designed and fabricated.

Five complete NAC-1 truck casks and two complete NFS-4 casks have been fabricated. Nuclear Fuel Services, Inc., (NFS) was the original owner of the NFS-4 casks. These casks are currently supplied by NAC which holds a long term lease agreement on them. Of the five NAC-1 casks, two are owned by a utility company (Duke Power $C_{0}$ ) and the other three are owned by NAC. All five of

(a) NAC-1 and NFS-4 casks are of the same design 
the NAC-1 casks and both NFS-4 casks were temporarily suspended from use by the NRC in 1979. Apparently there is some evidence of a manufacturing defect which may have caused one or more of the steel shells of the casks to warp or bow, potentially causing them to not meet the requirements of their Certificate of Compliance. Upon inspection and measurement of the casks' inner shells, it was determined that three of the NAC-1 casks ( 2 owned by NAC and one utility-owned cask) were within the license drawing tolerances and the NRC lifted the suspension imposed on these. The order (issued by NRC) that lifted the operating suspension of the three NAC-1 casks also revised the Certificate of Compliance to reduce the maximum allowable decay heat load in the cask from $11.5 \mathrm{~kW}$ to $2.5 \mathrm{~kW}$, required dry shipment only (no water coolant), and also required inspection and measurement of the casks' inner shells at least every six months. NAC is currently performing analyses required by NRC to restore the Certificate of Compliance for the NAC-1 and NFS-4 casks to its original form. NAC expects that all of the NAC-1 and NFS-4 casks will be recertified.

\subsection{Reference Truck Spent Fuel Shipping System}

In order to define shipping parameters (capacities, empty weights, etc.) required to model the spent fuel transportation network and calculate transportation costs, reference spent fuel shipping systems were selected. The reference spent fuel truck cask used in this study is the NAC-1, owned and operated by the Nuclear Assurance Corp. (NAC). The NAC-1 and identical NFS-4 casks have been used to transport more U.S. commercial spent fuel than any other cask design (NAC 1981). Figure 4.1 shows the important structural features of the NAC-1 cask. Descriptive information is primarily extracted from Elder (1981).

Nuclear Fuel Services Inc. (NFS) designed and fabricated the NFS-4 spent fuel shipping casks. These casks were licensed in 1972 for a design capacity of 1 PWR or 2 BWR current generation fuel assemblies. Nuclear Assurance Corp. (NAC) purchased the rights to the NFS-4 cask and redesignated it as the NAC-1. These cask systems operate as a legal-weight truck (LWT) system, i.e., the gross vehicle weight (tractor, trailer, cask, cargo, and ancillary equipment) is less than 33.3 MT $(73,280$ lbs.).

External dimensions of the NAC-1 cask are $1.27 \mathrm{~m}(4.2 \mathrm{ft}$.$) in diameter and$ $5.13 \mathrm{~m}(16.8 \mathrm{ft}$.$) in length. The internal cavity is 0.34 \mathrm{~m}(1.1 \mathrm{ft}$.$) in$ 


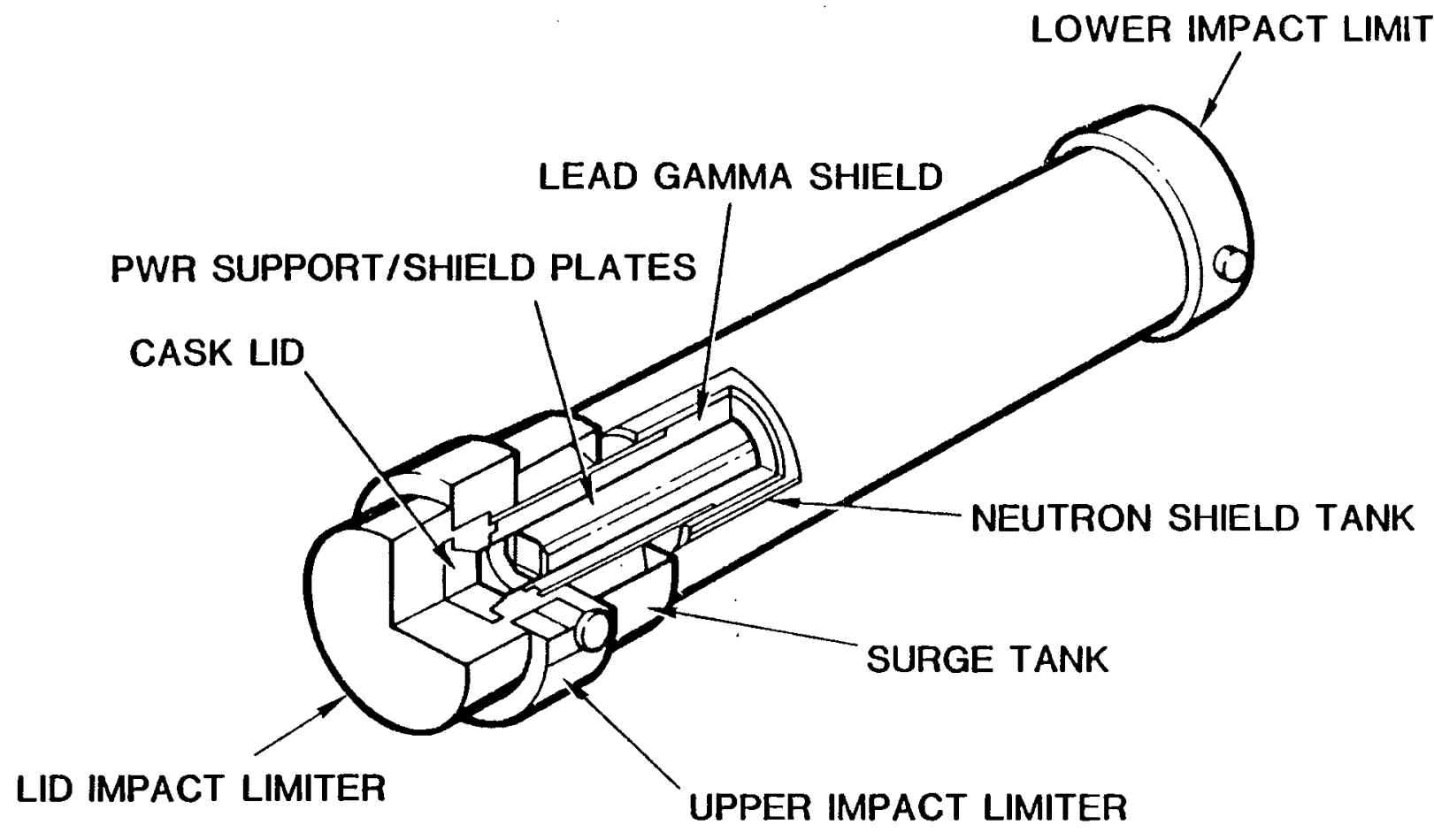

FIGURE 4.1. Structural Features of the NAC-1 Spent Fuel Cask 
diameter and $4.52 \mathrm{~m}(14.8 \mathrm{ft}$.$) long. The primary cask cavity consists of a$ nominal $0.8 \mathrm{~cm}(0.3 \mathrm{in}$,$) thick stainless steel pressure vessel surrounded by a$ $17 \mathrm{~cm}$ ( $5.6 \mathrm{in.)}$ thick lead gamma shield and a $3.2 \mathrm{~cm}$ (1.25 in.) thick stainless steel penetration barrier. Neutron shielding is provided by a borated waterethylene glycol solution contained in a compartmentalized tank surrounding the cask which is $11.4 \mathrm{~cm}$ (4.5 in.) thick. An expansion tank is provided to accommodate temperature changes of the water-antifreeze solution in the neutron shield tank. Stainless steel-sheathed balsa wood impact limiters are placed at each end of the cask for impact protection. Figure 4.2 shows a cross-section of the NAC-1 cask.

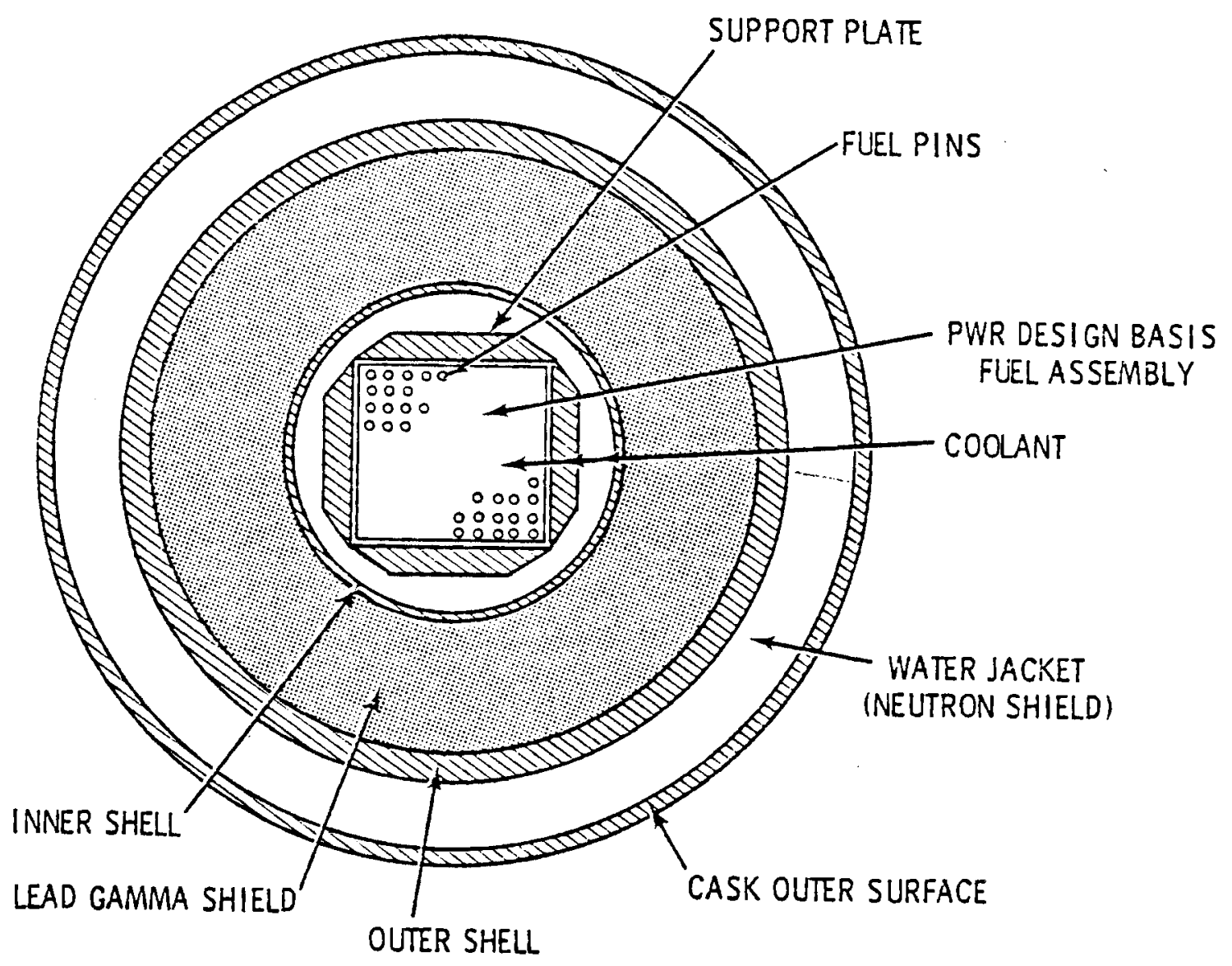

FIGURE 4.2. NAC-1 Spent Fuel Shipping Cask Cross Section 
The inner cavity of the cask is filled with water coolant. Water transfers decay heat from the spent fuel elements by convection to the inner cavity wall. Heat is conducted through the inner she11, lead gamma shield, and outer shell to the neutron shield where it is transferred by convection to the cask outer wal1. Heat is then conducted through the outer wall and rejected to the atmosphere by convection and radiation. No active cooling system is required. The maximum heat rejection capability of the cask is $11.5 \mathrm{~kW}$ (about $39,000 \mathrm{BTU} / \mathrm{hr})$.

The cask has a single lid which seals and shields the cask cavity. The lid is stainless steel and is attached to the cask by 6 high-strength bolts. Two teflon 0-rings provide the head seal. They are arranged so each may be pressure tested. Nominal cavity pressure is $1220 \mathrm{kPa}$ (175 psig). A rupture disc is provided that vents the cavity to the atmosphere when cavity pressure exceeds $7220 \mathrm{kPa}$ (1100 psig).

The bottom of the cask consists of a $20 \mathrm{~cm}(7.9 \mathrm{in.})$ thick disc of stainless steel welded to the main $3.2 \mathrm{~cm}(1.25 \mathrm{in.})$ thick cask shell and the inner cavity shell. The top end of the cask consists of a stainless steel ring flange welded to the cask shells in a similar fashion. There are two $1.3 \mathrm{~cm}$ (0.5 in.) drain holes in the bottom end of the cask. The drain holes open to the end of the cask cavity and are drilled through the gamma shield to ball valves imbedded in the cask outer perimeter. A $1.3 \mathrm{~cm}(0.5 \mathrm{in}$.) diameter rupture disc is buried in the cavity flange and connected to the cask cavity. The rupture disc assembly is mounted in a counterbore sealed by a cap and also has a safety relief valve for backup.

Two sets of trunions are used for normal cask handling and transport tiedown purposes. The upper set, attached to the upper impact limiter, is used for lifting the cask in conjunction with a special "swing-arm" type lifting yoke. The yoke is normally permanently locked to the lifting trunions throughout the complete handling cycle (loading or unloading). The lower trunions are off-set to provide a gravity pivot from the vertical loading and unloading position to the horizontal transport mode. 


\subsection{Reference Rail Spent Fuel Shipping System}

The reference rail spent fuel shipping system selected to define shipping parameters is the General Electric Co. Model IF-300. Descriptive information was primarily extracted from Elder et al. (1978). The IF-300 cask is primarily transported by railroad, although it is also designed to facilitate truck shipment on a special overweight basis for short distances. Only shipments by rail were considered in this study. This cask was licensed for a design capacity of 7 PWR or 18 BWR current generation fuel assemblies. Fuel is held within the cask cavity by a removable stainless steel basket. There are several basket configurations which may be used depending upon the specific fuel being shipped (PWR or BWR). There are also two heads which permit a variation in cask cavity length (longer cavity for BWR fuel). The IF-300 spent fuel shipping cask is shown in Figure 4.3.

Overall dimensions of the IF-300 cask include a diameter of $1.91 \mathrm{~m}(6.26$ $\mathrm{ft.})$ and lengths of $5.03 \mathrm{~m}(16.49 \mathrm{ft}$.$) or 5.28 \mathrm{~m}(17.31 \mathrm{ft.})$ for PWR or BWR fuel, respectively (different lid configurations). The internal cask cavity is $0.95 \mathrm{~m}$ ( $3.11 \mathrm{ft}$. ) in diameter and is $4.25 \mathrm{~m}$ (13.93 ft.) long for PWR fuel and $4.57 \mathrm{~m}$ (14.98 ft.) long for BWR fuel. The cask inner cavity is a stainless steel cylinder with $1.27 \mathrm{~cm}(0.5 \mathrm{in.})$ thick walls. The bottom is sealed with a $3.8 \mathrm{~cm}$ ( $1.5 \mathrm{in.})$ thick stainless steel plate. The upper end is welded to the closure flange.

Surrounding the inner cavity is a depleted uranium (DU) metal gamma shielding layer $10.2 \mathrm{~cm}(4.0 \mathrm{in.})$ thick. The DU shielding layer is surrounded by a $3.8 \mathrm{~cm}$ (1.5 in.) thick cylindrical outer vessel. Both the DU shielding layer and cask outer vessel are shrink-fitted in place to ensure good heat transfer characteristics. The bottom end shield is a $9.5 \mathrm{~cm}(3.75 \mathrm{in.})$ thick DU metal casting.

The cylindrical portion of the cask is encircled by a thin-walled corrugated stainless steel water jacket. The water jacket extends axially from the upper valve box to a point slightly above the cask bottom, thus masking the active fuel zone. Neutron shielding is provided by water in this structure. The surface of the water jacket is corrugated for heat transfer purposes. Antifreeze may be added to the water in this structure when the cask is subjected to cold ambient temperatures. 


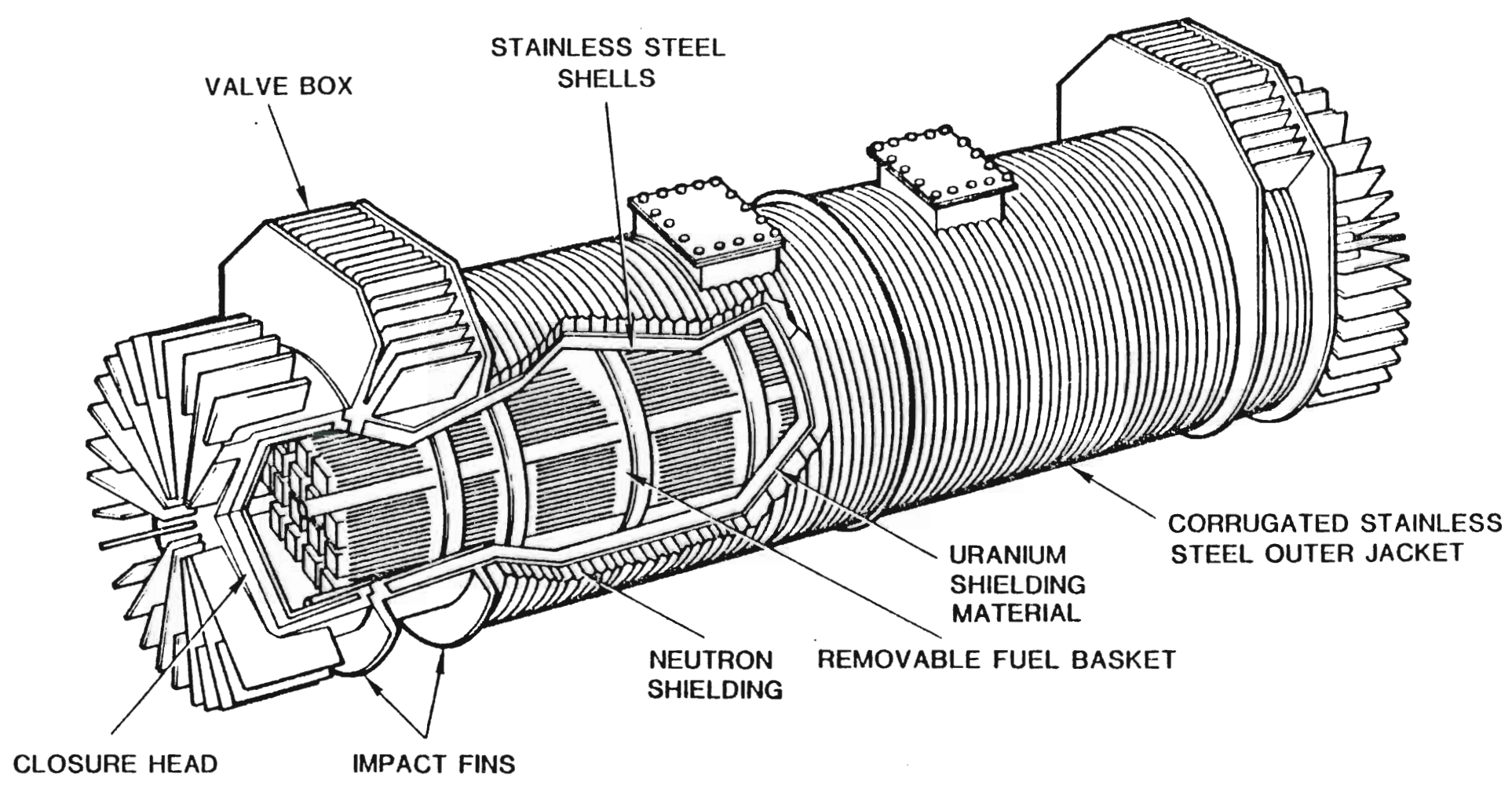

FIGURE 4.3. Structural Features of the IF-300 Spent Fuel Shipping Cask 
The IF-300 can be equipped with two different heads. These heads are provided to match the different cavity lengths required for PWR and BWR fuel assemblies. Shielding in the head is provided by $7.6 \mathrm{~cm}(3.0 \mathrm{in}$.) of DU metal. The closure head is sealed with a metallic gasket. The maximum normal operating pressure for the cask cavity is about $1400 \mathrm{kPa}$ (200 psig), and the design working pressure is $2800 \mathrm{kPa}$ ( $400 \mathrm{psig}$ ) at a material temperature of $435^{\circ} \mathrm{C}\left(815^{\circ} \mathrm{F}\right)$. A pressure relief valve, set to open at $2600 \mathrm{kPa}$ (375 psig) is provided for protection against overpressure. The cask cavity is equipped with two nuclear service valves, one in each of two valve boxes (see figure 4.3).

Decay heat from the irradiated fuel assemblies is transferred to the cask cavity walls by natural circulation of coolant water in the cavity. Heat is then conducted through the cask walls (stainless steel shells and DU shielding layer) to the neutron shield, transferred by convection through the neutron shield to the corrugated outer wall and dissipated to the atmosphere by radiation and convection. A cask cooling system is provided (and mounted on the railcar) that blows air in a direction perpendicular to the cask surface. Air is blown through four ducts, running the length of the cask and 90 degrees apart, bisecting the four quadrants. Cooling air is supplied by two air-cooled diesel-engine driven blowers. The maximum heat removal capability of the cask system is $76 \mathrm{~kW}(260,000 \mathrm{BTU} / \mathrm{hr})$. Under low fuel decay heat conditions, the internal cask cavity may be shipped dry (air coolant) with a thermal limit of $11.7 \mathrm{~kW}$.

The IF-300 cask is normally transported by rail on a $100 \mathrm{Mg}$ (110 ton) capacity, four-axle flatcar. The cask is mounted on a skid and supported on a saddle at the head end and a cradle at the bottom end. The shipping cask, skid, and railcar are shown in Figure 4.4. The saddle and cradle are welded directly to the skid frame. The U-shaped saddle supports that cask at its upper lifting rings. Hardened pins are inserted through the lifting rings to provide vertical and lateral restraint of the head end. Axial restraint for the total cask weight is provided by the ears of the saddle. The pivot cradle consists of two pedestals and a counterbalanced cradle that supports the cask. The cradle pivots between the two pedestals on two trunions. 


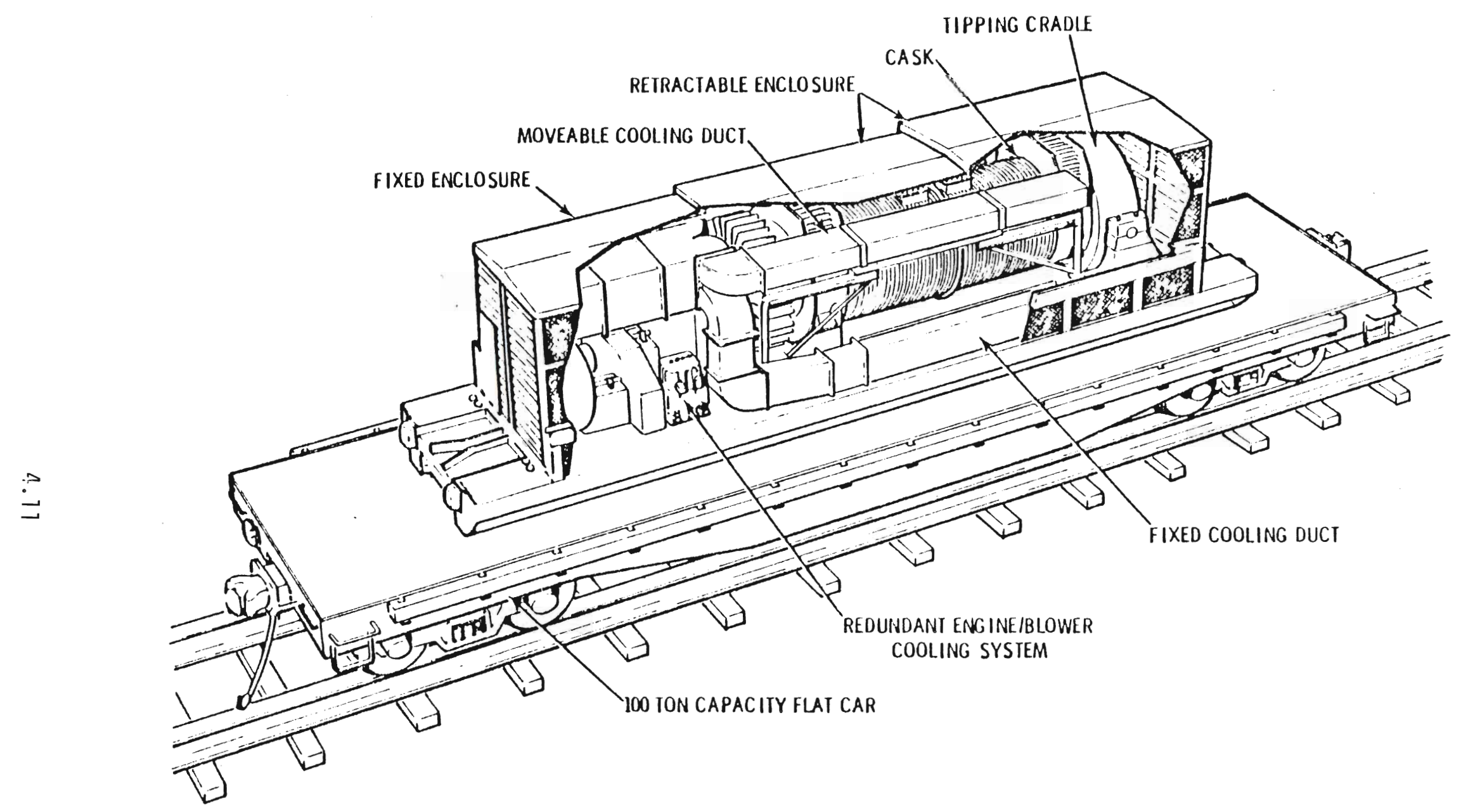

FIGURE 4.4. IF-300 Spent Fuel Shipping System 



\subsection{SPENT FUEL TRANSPORTATION COSTS}

This section defines the cost factors input to the computer models for spent fuel transportation cost calculations. Cost estimates for these services are based on the assumption that they are provided by private industry as a commercial venture. Total transportation costs are the sum of five factors; 1) round-trip shipping charges, 2) shipping container leasing fees, 3) special equipment and security costs, (a) 4) demurrage fees and, 5) facility handling costs. These factors are discussed in the following subsections. Unit transportation costs are calculated and summarized at the end of this section. All charges listed are as of June, 1982.

\subsection{SHIPPING (FREIGHT) CHARGES FOR LWR SPENT FUEL}

Shipping (freight) charges are the fees assessed by truck or railroad carrier companies to deliver the spent fuel shipping containers to the terminal facilities. These charges are assessed per unit weight of the cargo and shipping container, i.e., the weights of the truck tractor and trailer or railcar are not included in the shipping charges. The actual fee charged by a truck or rail carrier to transport spent fuel cannot be determined until a contract is negotiated due to the current deregulation of the transportation industry. These charges are based on several conditions, including shipment origins, destinations, sizes, weights, specific routes, the volume shipped, frequency of shipments, and existing competition. Fortunately, basic shipping charge structures for spent fuel do exist in various forms in the U.S. Shipping charges for truck and rail shipments are discussed in the following subsections.

\subsubsection{Truck Shipping Charges}

All truck shipping charges included in this report are from a single carrier (Tri-State Motor Transit Co. 1981) to provide a uniform basis within this study for calculating these charges. This carrier services the 48 contiguous states and, furthermore, has the capability to comply with NRC

(a) These charges are required by NRC Regulations (10 CFR 73) 
requirements for shipping spent fuel. Other carriers may use different charges.

Basic freight charges for spent fuel shipments using legal-weight and legal-dimension vehicles do not vary across the country. Basic weight and dimension charges are shown in Appendix C, Table C.1. There are two columns for shipping charges on Table C.1; one for shipments with cargo (loaded) and one for shipments without cargo (empty). Freight charges are calculated by finding the charge rate per hundred pounds $(a)$ on Table C.1 for the one-way transportation distance in question and multiplying this rate by the number of 100-pound increments in the loaded and empty cask system (commodity) weights. The commodity weights used in these calculations are the combined weights of everything placed on the truck trailer (i.e., cask, spent fuel, tie-downs, impact limiters, and personnel barrier) and are not the same as the gross vehicle weight. Total round-trip shipping charges are the sum of the one-way charges for loaded and empty shipments for each specific transport distance.

\subsubsection{Rail Shipping Charges}

Rail shipping charges are more complicated than truck shipping charges. Rail charges are often not uniform with the distance traveled and can be affected by topography, state regulations, competition, and the route traveled. The shipping charges developed in this section are for rail general freight service. It is assumed that Special Trains(b) will not be used for future spent fuel shipments. This assumption is based on the outcome of recent litigation between shippers and rail carriers regarding the assessment of special train freight rates (U.S. Law Week 1980).

Freight charges assessed by rail carriers are based on transporting a commodity between "rate-basing areas" which are major rail points where branch lines connect to local towns or communities. Specific origins and destinations must be defined in order to determine which rate-basing area a particular facility is within. The rail shipping charges are assessed between rate-basing

(a) 100 pounds $=45.45 \mathrm{~kg}$.

(b) Special trains are defined as trains made up solely for the shipment of one commodity or for one shipper. 
areas regardless of the route or mileages traveled. For example, assume a utility wishes to make a shipment of spent fuel from the state of Washington to Illinois (this is a hypothetical shipment for illustration purposes, only). The shipping charge is calculated between the rate-basing areas that contain the two facilities regardless of whether a direct route is taken or whether the shipment travels through Texas on the way to Illinois. Therefore, "generic" rail shipping charges do not exist.

The rail freight charges used in this study were obtained from a recently published report (Cole et al 1982). The rail freight charge information in this report was obtained from appropriate railroad tariffs by the DOE/Hanford Traffic Managers, except that recently established Northeastern U.S. single car rates could reduce charges on shipments to, from, or within that region. Interregional rates were used for uniformity. The rates quoted in the report (Cole et al 1982) are not necessarily the lowest rates applicable to a specific shipment. Deregulation permits negotiation of the rates to a certain extent. The rail freight rates used in this study are discussed in more detail in Appendix c. The procedure used to calculate the rail freight charges for the specific transport distances used in this study is identical to the procedure used to calculate truck freight charges using empty and loaded freight rates. The commodity weight used in these procedures is the combined weight of everything placed on the railcar. For the reference rail cask in this study, the commodity weight is the sum of the weights of the cask, spent fuel (if loaded), impact limiters, personnel barrier, tie-downs, and the skid assembly (includes cooling equipment and diesel fuel for the blower system).

\subsection{SPECIAL EQUIPMENT AND SECURITY COSTS}

Since spent fuel might be a target for theft or sabotage, physical protection is required when shipments are in transit. Requirements for physical protection of spent fuel shipments are delineated by NRC regulations (10 CFR 73). These requirements and their costs are discussed in this section for truck and rail shipments of spent fuel.

NRC regulations (10 CFR 73) require specially equipped vehicles and specially trained personnel for spent fuel shipments. The regulations require that these shipments must be scheduled, in writing, at least 7 days in 
$\$ 1000$ fee is assessed by the carrier. When a carrier is required to furnish armed driver(s) or escorts(s), an additional charge is assessed. Furthermore, if a separate escort vehicle is required or necessary, another fee is added to the shipment costs.

The regulations state that a truck transport vehicle within a heavily populated area must be occupied by a least two individuals, one of whom serves as an escort, and either 1) escorted by an armed member of the local law enforcement agency or 2) preceeded by a separate vehicle and followed by an additional vehicle, each vehicle containing at least one armed guard. A spent fuel truck shipment not within a heavily populated area must be either 1) occupied by at least one driver and escorted by a separate vehicle occupied by at least two escorts, or 2) escorted as required in heavily populated areas. For this study, it is assumed that the transport vehicles will not travel through heavily populated areas, thus eliminating the need for separate escort vehicles.

Special equipment and security costs for shipments of spent fuel by truck were obtained from a carrier company (Tri-State Motor Transit Co. 1981). This company charges $\$ 0.12 / \mathrm{km}(\$ 0.20 / \mathrm{mi}$.) for each armed escort/driver (both persons in the vehicle can serve as drivers and escorts). Two armed escorts/drivers are required for a total of $\$ 0.24 / \mathrm{km}(\$ 0.40 / \mathrm{mi}$.) for these services. An addi tional special equipment charge of $\$ 0.57$ per loaded $\mathrm{km}$ ( $\$ 0.92$ per loaded mile) is also required by the carrier company.

The charges listed above are multiplied by the total distance traveled to obtain the special equipment and security costs for spent fuel shipments. The travel distance is normally based on special equipment and personnel domiciled at Joplin, Missouri (home office of the carrier company). Distances are computed from Joplin, Missouri, to the point of origin of the shipment, then through to the destination, then back to the domicile point of the shipment. For simplification purposes and because specific routes are not defined for this study, the special equipment and security costs will be computed for only the distances between the shipment origin and destination.

Rail shipments of spent fuel require security provisions and special equipment similar to truck shipments. Rail shipments within heavily populated areas 
must be accompanied by two armed escorts that may or may not be members of the local law enforcement agency. A rail shipment not within a heavily populated area must be accompanied by at least one armed escort (10 CFR 73). For this study it is assumed that rail shipments will have two escorts to ensure continuous surveillance of the transport vehicle.

At this time, rail carrier companies have no provisions to supply an armed escort service. It is expected that this service will be provided by the shipper. Rail carriers have indicated they will supply a caboose or car for the escorts to ride in. The charge for this service would be the price of a coach-class passenger ticket. This charge amounts to about $\$ 0.06 \mathrm{per} \mathrm{km}(\$ 0.09$ per mile) after escalation of this charge obtained by Cole et al (1982).

Rail security costs must also include the wages and living expenses of the escorts. It is assumed that trained security personnel will cost about $\$ 150$ per day for each, including expenses. Cole et al (1982) found that the average distance a train can travel in one day varies with the distance traveled, as shown in Table 5.1. These average rail speeds were determined from information supplied by the DOE/Hanford Traffic Managers Office. These averages cause the charge for continuous surveillance to range from $\$ 2.18$ per $\mathrm{km}$ ( $\$ 3.48 \mathrm{per} \mathrm{mi}$. )

\section{TABLE 5.1. Average Rail Transity Speeds and
Rail Security Costs}

\begin{tabular}{c}
$\begin{array}{c}\text { One-Way Shipping } \\
\text { Distance, } \mathrm{km}(\mathrm{mi} .)\end{array}$ \\
\hline $800(500)$ \\
$1200(750)$ \\
$1600(1000)$ \\
$2400(1500)$ \\
$3200(2000)$ \\
$4000(2500)$
\end{tabular}

\begin{tabular}{cc}
$\begin{array}{c}\text { Average Speed, } \\
\mathrm{km} / \mathrm{d}(\mathrm{mi} / \mathrm{d})\end{array}$ & $\begin{array}{c}\text { Security } \\
\text { Costs, \$/Shipment }\end{array}$ \\
\cline { 2 - 2 } $140(88)$ & 1740 \\
$140(88)$ & 2690 \\
$140(88)$ & 3630 \\
$230(143)$ & 3720 \\
$290(182)$ & 3810 \\
$290(182)$ & 4500
\end{tabular}

(a) Based on data obtained by Cole et al. (1982). Security costs include wages, living expenses, and passenger train tickets for 2 escorts to ensure continuous surveillance of the loaded spent fuel rail cask. 
for an $800 \mathrm{~km}(500 \mathrm{mi}$.$) shipment to \$ 1.13$ per $\mathrm{km}(\$ 1.80$ per $\mathrm{mi}$. ) for a $4000 \mathrm{~km}$ (2500 mi.) shipment. Adding the cost of the coach class passenger ticket causes the total cost for the rail escort service to range between the values shown in Table 5.1 .

\subsection{SHIPPING SYSTEM LEASING FEES}

One of the bases for this study is that spent fuel transportation services will be supplied by private industry. Therefore, the total transportation costs must include a fee for rental or lease of spent fuel shipping systems from commercial cask supplier companies. These charges are based on capital cost estimates that reflect manufacturers profits, engineering and development costs, sales, overheads, and similar expenses in addition to material and fabrication costs. Leasing fees also include maintenance costs and a use factor. Capital cost estimates for the reference truck and rail spent fuel shipping systems (including the cask, tie-down system, and other necessary features including auxiliary cooling equipment for rail systems) were calculated in document DOE/ET-0028 (DOE-1979) in mid-1976 dollars. These costs are converted to mid-1982 dollars using an escalation factor of 1.71 . This results in capital cost estimates (assuming purchased equipment is supplied repetitively on a competitive basis) for the truck and rail shipping systems of $\$ 1.5$ million and $\$ 5.1 \mathrm{million}$, respectively.

The cask leasing fees used in this study are calculated assuming casks will be supplied repetitively on a competitive basis and will be used at or near their maximum efficiency, assumed to be $80 \%$ or 292 days per year. An inflation-free rate-of-return of $10 \%$ per year is assumed in the calculations. It is felt that this rate of return is appropriate, assuming relatively low risks for such factors as technical obsolescence of casks (future cask systems will not likely be substantially different than current casks) and collapse of the spent fuel transportation industry. The cask leasing fee calculations also assume maintenance costs are $2 \%$ of the initial capital costs per year and cask systems have economic 1 ifetimes of 10 years. Using the cask capital cost estimates above and standard capital recovery factor tables, the cask leasing fee for the NAC-1 truck system is calculated to be about $\$ 940$ per day and for 
the IF-300 rail system is about $\$ 3190$ per day. These charges are in constant mid-1982 dollars.

Calculations of the cask leasing fees for each of the shipping distances in this study requires the round-trip transit times. Transit times are determined using the average speeds of the truck and rail casks. It has been shown that trucks can travel up to $1440 \mathrm{~km} /$ day (900 $\mathrm{mi} . /$ day), assuming two drivers can continuously operate the vehicle (Cole et al 1982). Average rail speeds are difficult to characterize because of their frequent stops and potential long waits in rail yards. However, it was estimated (Cole et al 1982) that average speeds for rail shipments vary with the transit distance, as shown previously in Table 5.1 .

\subsection{DEMURRAGE FEES}

The fourth fee included in the transportation cost calculations is a charge for demurrage or detention of transportation equipment and drivers (or escorts) at the terminal facilities while the spent fuel cargo is being loaded or unloaded. This fee is assessed to compensate for idle equipment and for the drivers wages and living expenses during this time. To calculate these charges, turnaround times must be determined for the truck and rail shipping systems. Turnaround time is the length of time between arrival of a cask at a terminal facility and departure of the cask from the facility, after either loading or unloading operations occur. The average time to load or unload the truck and rail casks as well as the amount of time the shipping casks wait for loading or unloading operations to begin and the amount of time the casks wait after loading or unloading and before departure from the facility are included in the turnaround times. The two waiting times are referred to as "queuing" times. The terminal facility turnaround times are assumed to be 24 hours for truck shipments and 48 hours for rail shipments.

Typically, demurrage fees are negotiated prior to the shipments and vary between contracts. Demurrage fees for truck shipments were obtained from a truck carrier company (Tri-State Motor Transit Co., 1981) and result in a charge of $\$ 490$ per day per shipment. In addition, the leasing fee for the truck shipping system for the duration of turnaround time must be added. Thus, the demurrage fee for truck shipments is $\$ 3365$ per handling operation assuming 
drivers/escorts deliver a cask and wait at the terminal facility for the same cask before departing. This fee is assessed at both the loading and unloading facilities for a total of $\$ 6730$ per round-trip shipment.

Escorts for rail shipments are assumed to return to their domicile locations or return to another shipment origin as soon as they arrive at the destination facility. Therefore, rail demurrage fees need not include the wages and living expenses of the escorts. The resulting demurrage fee consists only of the cask leasing fee for the duration of turnaround at the facility, or $\$ 6380$ for the assumed 48 hour turnaround time. This charge is assessed at both the origin and destination facilities for a total of $\$ 12,760$ per roundtrip shipment.

\subsection{Facility Handling Costs}

The final element of transportation costs for this study are the costs incurred for loading or unloading spent fuel shipping casks at the terminal facilities. These costs are difficult to characterize accurately. They were included here to avoid biasing results in favor of the truck shipping mode. Without handling costs, a significant cost advantage exists for truck shipping (on a cost per mile or cost per MTU basis). Therefore, handling costs for truck and rail shipments are developed in this section and will be incorporated in the transportation unit costs. Capital costs for additional truck receiving facilities are not included in the analysis due to large uncertainties. However, it is believed that this would not affect the results significantly.

The dominant component of the facility handling costs is the cost of labor. For this study, the personnel requirements for loading and unloading a shipping cask are shown in Table 5.2 (Lambert et a1. 1981). Operation $A$ on Table 5.2 requires two persons; one health-physics technician and one person to inspect the cask and vehicle. Operations $B$ to $E$ require a health-physics technician and two cask/fuel handling persons. The total labor requirements for loading or unloading the NAC-1 cask is about 43 man-hours and for the IF300 cask is about 84 man-hours. It is assumed that the idle times when the casks are waiting for an available handling bay or waiting for their over-theroad movers are essentially free of handling costs. It is also recognized that a supervisor will most likely be present in the handling facilities. The 
TABLE 5.2. Labor Requirements for Loading or Unloadipg
the Reference Spent Fuel Shipping Casks

\begin{tabular}{|c|c|c|c|c|c|}
\hline \multirow{2}{*}{\multicolumn{2}{|c|}{ Operation (a) }} & \multicolumn{2}{|c|}{ NAC-1 } & \multicolumn{2}{|c|}{ IF -300} \\
\hline & & People & Hours & No. of People & Hours \\
\hline A. & $\begin{array}{l}\text { Inspection, Moni- } \\
\text { toring, and Pre- } \\
\text { paration }\end{array}$ & 2 & 1.0 & 2 & 1.8 \\
\hline B. & $\begin{array}{l}\text { Cask Unloading, } \\
\text { Washing, Prep., } \\
\text { Lid Removal, and } \\
\text { Placement in Pool }\end{array}$ & 3 & 3.5 & 3 & 6.7 \\
\hline C. & Fuel Movement $(c)$ & 3 & 0.5 & 3 & 4.5 \\
\hline D. & $\begin{array}{l}\text { Lid Replacement } \\
\text { Removal from Pool, } \\
\text { Decon., and Drying }\end{array}$ & 3 & 2.7 & 3 & 3.9 \\
\hline E. & $\begin{array}{l}\text { Cask Prep. for Load- } \\
\text { Out, Replace on } \\
\text { Vehicle, Install } \\
\text { Ancillary Equipment, } \\
\text { Move Outside }\end{array}$ & 3 & 6.9 & 3 & 11.6 \\
\hline & TOTAL OPERATING TIME & & 14.6 & & 28.5 \\
\hline & TOTAL MANHOURS & & 42.8 & & 83.7 \\
\hline
\end{tabular}

\footnotetext{
(a) Source for operating times is document NEDG-24905 (Lambert et al. 1982).

(b) Operations do not include idle times waiting for an available handling bay or for pick-up by over-the-road movers.

(c) These times are for loading or unloading BWR fuel assemblies at the rate of 4 assemblies/hr.
}

costs for this person are assumed to be included in the overhead expenses for the operating personnel. Labor charges are calculated assuming the wages, benefits, and overhead expenses for the operating personnel amount to $\$ 30.00$ per hour. A $50 \%$ contingency is added to this to cover occasional overtime, utility and material requirements, waste disposal, and special handling equipment. Therefore, the cost for the handling operations is about $\$ 45.00 / \mathrm{hr}$. The resulting facility handling costs are $\$ 3780 /$ rail cask and $\$ 1935 /$ truck cask. 


\subsection{Unit Transportation Costs for LWR Spent Fuel}

This section contains the unit transportation costs for spent nuclear fuel that were developed for this study. These costs are the sum of the freight charges, cask leasing fees, special equipment and security costs, demurrage fees, and handling costs. The final information required to calculate unit transportation costs is the commodity weight or the sum of the weights of everything placed on the railcar or truck trailer. The truck and rail commodity weights are required to calculate freight charges. It is important to note that the commodity weights include the weights of the cask and ancillary equipment. This means that, since the cask and other equipment are reusable, they will be returned empty to transport more fuel thus, incurring freight charges even though no fuel is transported on the return trip.

The difference between the commodity weights for empty and loaded spent fuel shipments is the weight of the fuel assemblies themselves. The average weights for truck and rail shipments are developed assuming two-thirds of the commercial LWRs are PWRs and one-third are BWRs. Therefore, it is assumed that approximately two-thirds of the future spent fuel shipments will be PWR fuel assemblies. The average weights of PWR and BWR fuel elements are $658 \mathrm{~kg}$ (1450 lbs.) and $284 \mathrm{~kg}$ (625 lbs.), respectively. Using the reference truck and rail cask capacities, the average cargo weights are calculated to be $630 \mathrm{~kg}$ (1385 lbs.) per truck shipment and $4775 \mathrm{~kg}(10,500$ lbs.) per rail shipment. The commodity weights used to calculate freight charges in this study are shown below.

$\underline{N A C-1} \quad \underline{I F-300}$

Commodity Weights

$\begin{array}{lll}\text { Empty, kg (1bs.) } & 23,700(52,260) & 79,400(175,100) \\ \text { Loaded, kg (1bs.) } & 24,330(53,650) & 84,200(185,660)\end{array}$

Tables 5.3 and 5.4 summarize the transportation unit costs (dollars per shipment) for truck and rail spent fuel shipments for the one-way distances in this study. The costs are input to the cost models described in section 3.2 . 
It is felt that the costs shown in these tables are representative approximations and provide reasonable bases for this study. 
TABLE 5.3. Summary of Unit Transportation Costs for Shipments of Spent Fuel in the Reference Truck Shipping System

\begin{tabular}{|c|c|c|c|c|c|}
\hline $\begin{array}{l}\text { ONE-WAY } \\
\text { SHIPPING } \\
\text { DISTANCE } \\
\mathrm{km} \text { (mi.) }\end{array}$ & $\begin{array}{c}\text { ROUND-TRIP } \\
\text { SHIPPING } \\
\text { CHARGE } \\
\text { (\$/Shipment) } \\
\end{array}$ & $\begin{array}{c}\text { ROUND-TRIP } \\
\text { CASK LEASING } \\
\text { FEE } \\
\text { (\$/SHIPMENTL }\end{array}$ & $\begin{array}{c}\text { ROUND-TRIP } \\
\text { SECURITY } \\
\text { COSTS } \\
\text { (\$/SHIPHIENT) } \\
\end{array}$ & $\begin{array}{l}\text { HANDLING AND } \\
\text { DEMURRAGE } \\
\text { FEES } \\
\text { (\$ } \$ \text { SHIPIENT })^{(a)}\end{array}$ & $\begin{array}{c}\text { ROUND-TRIP } \\
\text { TRANSPORTATION } \\
\text { COST } \\
(\$ / \text { SHIPMENT) }\end{array}$ \\
\hline $800(500)$ & 2740 & 940 & 860 & 6730 & 11,270 \\
\hline $1200(750)$ & 3710 & 1880 & 1290 & 6730 & 13,610 \\
\hline $1600(1000)$ & 4630 & 2820 & 1720 & 6730 & 15,900 \\
\hline $2400(1500)$ & 6950 & 3760 & 2580 & 6730 & 20,020 \\
\hline $3200(2000)$ & 9300 & 4700 & 3440 & 6730 & 24,170 \\
\hline $4000(2500)$ & 11,640 & 5640 & 4300 & 6730 & 28,130 \\
\hline
\end{tabular}

(a) Includes demurrage fees assessed at both ends of the transportation link, i.e., at both the loading and unloading facilities. Includes cask leasing fee for duration of handling. 
TABLE 5.4. Summary of Unit Transportation Costs for Shipments of Spent Fuel in the Reference Rail Shipping System

\begin{tabular}{|c|c|c|c|c|c|}
\hline $\begin{array}{l}\text { ONE-WAY } \\
\text { SHIPPING } \\
\text { DISTANCE } \\
\mathrm{km}(\mathrm{mi} .)\end{array}$ & $\begin{array}{c}\text { ROUND-TRIP } \\
\text { SHIPPING } \\
\text { CHARGE } \\
\text { (\$/Shipment) } \\
\end{array}$ & $\begin{array}{c}\text { ROUND-TRIP } \\
\text { CASK LEASING } \\
\text { FEE } \\
\text { (\$/SHIPMENT) }\end{array}$ & $\begin{array}{c}\text { ROUND-TRIP } \\
\text { SECURITY } \\
\text { COSTS } \\
\text { (\$/SHIPMENT) } \\
\end{array}$ & $\begin{array}{l}\text { HANDL ING AND } \\
\text { DEMURRAGE } \\
\text { FEES } \\
\text { (\$/SHIPMENT) }^{(\dot{a})}\end{array}$ & $\begin{array}{c}\text { ROUND-TRIP } \\
\text { TRANSPORTATION } \\
\text { COST } \\
(\$ / \text { SHIPIUENT }) \\
\end{array}$ \\
\hline $800(500)$ & 20,480 & 35,100 & 1740 & 20,320 & 77,640 \\
\hline $1200(750)$ & 25,990 & 54,200 & 2690 & 20,320 & 103,200 \\
\hline $1600(1000)$ & 30,750 & 73,400 & 3630 & 20,320 & 128,100 \\
\hline $2400(1500)$ & 39,030 & 73,400 & 3720 & 20,320 & 136,470 \\
\hline $3200(2000)$ & 46,230 & 73,400 & 3810 & 20,320 & 143,760 \\
\hline $4000(2500)$ & 52,700 & 86,100 & 4500 & 20,320 & 163,620 \\
\hline
\end{tabular}

(a) Includes demurrage fees and handling costs assessed at both ends of the transportation 1ink, i.e., at both the loading and unloading facilities. Includes cask leasing fee for duration of handling. 


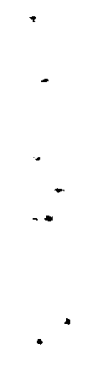




\subsection{RESULTS OF SPENT FUEL TRANSPORTATION LOGISTICS AND COSTS ANALYSIS}

Results of this spent fuel transportation logistics and cost analysis include the annual number of truck and rail shipments, numbers of shipping casks required to perform the shipments, and the annual transportation costs for each of the four spent fuel management scenarios in this study. Only costs related to transporting spent fuel are included, i.e., costs for construction of facilities, and packaging (when needed) are not included. The results can be affected by utilizing a different set of assumptions.

This section is composed of two sub-sections. In the first, transportation hardware requirements are presented. The second subsection presents and discusses the transportation costs associated with each scenario.

\subsection{RESULTS OF THE SPENT FUEL TRANSPORTATION HARDWARE REQUIREMENTS ANALYSIS}

This section presents the results of the spent fuel cask requirements analysis for each of the four scenarios under consideration in this study. The numbers of shipments and numbers of truck and rail cask systems required to provide the spent fuel transportation services for each of the four scenarios in this study are shown in Tables 6.1 and 6.4. Included are the estimated numbers of spent fuel transshipments. Cask requirements for the transshipments are included in the total cask requirements and are not shown separately. It was assumed that on-site spent fuel transshipments will be performed in rail casks because such short-distance transfers take about the same amount of time whether rail casks or truck casks are used. Thus, there would not be a significant economic advantage for using truck casks in short-distance transfers. It was also assumed that spent fuel transshipments from the Cooper Nuclear Station to the Morris, Illinois storage facility (DOE 1982) will be done only in rail casks, as indicated in telephone contacts with General Electric Co. personnel involved in this transfer. Transshipments from the San Onofre Nuclear Station to the Morris facility (DOE 1982) are assumed to occur using the reference shipping mode split of $75 \%$ rail and $25 \%$ truck. Intrautility transshipments using utility-owned spent fuel casks are not included because they do not require the spent fuel transportation services considered in this study. 
TABLE 6.1. Near-Term Spent Fuel Transportation Hardware Requirements - Reference Scenario/75\% Rail Shipping

\begin{tabular}{|c|c|c|c|c|c|c|}
\hline \multirow[b]{2}{*}{ Year } & \multicolumn{2}{|c|}{$\begin{array}{l}\text { Number of } \\
\text { Off-Site } \\
\text { Shipments }\end{array}$} & \multicolumn{2}{|c|}{$\begin{array}{c}\text { Number of } \\
\text { On-Site } \\
\text { Transshipments }(\mathrm{a}) \\
\end{array}$} & \multicolumn{2}{|c|}{$\begin{array}{c}\text { Total } \\
\text { Number of } \\
\text { Casks Required } \\
\end{array}$} \\
\hline & Truck & Rail & Truck & Rail & Truck & Rail \\
\hline 1982 & 0 & $29^{(b)}$ & 0 & 0 & 0 & 1 \\
\hline 1983 & $18^{(b)}$ & $40^{(b)}$ & 0 & 0 & 1 & 3 \\
\hline 1984 & 97 & 29 & 0 & 0 & 2 & 3 \\
\hline 1985 & 41 & 18 & 0 & 23 & 1 & 2 \\
\hline 1986 & 259 & 13 & 0 & 10 & 4 & 1 \\
\hline 1987 & 1983 & 206 & 0 & 11 & 29 & 18 \\
\hline 1988 & 1830 & 229 & 0 & 18 & 28 & 20 \\
\hline 1989 & 1940 & 210 & 0 & 11 & 28 & 18 \\
\hline 1990 & 1884 & 217 & 0 & 0 & 28 & 19 \\
\hline 1991 & 1816 & 227 & 0 & 0 & 27 & 19 \\
\hline 1992 & 2016 & 200 & 0 & 0 & 29 & 17 \\
\hline 1993 & 1804 & 229 & 0 & 0 & 27 & 20 \\
\hline 1994 & 1734 & 241 & 0 & 0 & 26 & 21 \\
\hline 1995 & 1990 & 249 & 0 & 0 & 29 & 22 \\
\hline
\end{tabular}

(a) Represents numbers of intra-utility transshipments reported in DOE (1982).

(b) Transshipments to Morris, Illinois storage facility only. Does not include transshipments made with utility-owned spent fuel casks. 
TABLE 6.2. Near-Term Spent Fuel Transportation Hardware Requirements - Consolidated Fuel Shipping Scenario/75\% Rail Shipping

\begin{tabular}{|c|c|c|c|c|c|c|}
\hline \multirow[b]{2}{*}{ Year } & \multicolumn{2}{|c|}{$\begin{array}{r}\text { Number of } \\
\text { Off-Site } \\
\text { Shipments } \\
\end{array}$} & \multicolumn{2}{|c|}{$\begin{array}{c}\text { Number of } \\
\text { On-Site }(a) \\
\text { Transshipments } \\
\end{array}$} & \multicolumn{2}{|c|}{$\begin{array}{c}\text { Total } \\
\text { Number of } \\
\text { Casks Required } \\
\end{array}$} \\
\hline & Truck & Rail & Truck & Rail & Truck & Rail \\
\hline 1982 & 0 & $15^{(b)}$ & 0 & 0 & 0 & 1 \\
\hline 1983 & $9^{(b)}$ & $20^{(b)}$ & 0 & 0 & 1 & 2 \\
\hline 1984 & 49 & $1 \dot{5}$ & 0 & 0 & 1 & 1 \\
\hline 1985 & 21 & 9 & 0 & 12 & 1 & 1 \\
\hline 1986 & 130 & 7 & 0 & 5 & 2 & 1 \\
\hline 1987 & 992 & 103 & 0 & 6 & 15 & 9 \\
\hline 1988 & 915 & 114 & 0 & 9 & 14 & 10 \\
\hline 1989 & 970 & 105 & 0 & 6 & 14 & 9 \\
\hline 1990 & 942 & 109 & 0 & 0 & 14 & 10 \\
\hline 1991 & 908 & 114 & 0 & 0 & 14 & 10 \\
\hline 1992 & 1008 & 100 & 0 & 0 & 15 & 9 \\
\hline 1993 & 902 & 114 & 0 & 0 & 14 & 10 \\
\hline 1994 & 867 & 120 & 0 & 0 & 13 & 11 \\
\hline 1995 & 995 & 125 & 0 & 0 & 15 & 11 \\
\hline
\end{tabular}

(a) Represents numbers of intra-utility transshipments reported in DOE (1982).

(b) Transshipments to Morris, Illinois storage facility only. Does not include transshipments made with utility-owned spent fuel casks. 
TABLE 6. 3. Near-Term Spent Fue1 Transportation Hardware Requirements - Delayed Reprocessing Scenario/75\% Rail Shipping

\begin{tabular}{|c|c|c|c|c|c|c|}
\hline \multirow[b]{2}{*}{ Year } & \multicolumn{2}{|c|}{$\begin{array}{l}\text { Number of } \\
\text { Off-Site } \\
\text { Shipments }\end{array}$} & \multicolumn{2}{|c|}{$\begin{array}{c}\text { Number of } \\
\text { On-Site } \\
\text { Transshipments }(a) \\
\end{array}$} & \multicolumn{2}{|c|}{$\begin{array}{c}\text { Total } \\
\text { Number of } \\
\text { Casks Required } \\
\end{array}$} \\
\hline & Truck & Rai1 & Truck & Rail & Truck & Rai1 \\
\hline 1982 & 0 & $29^{(b)}$ & 0 & 0 & 0 & 1 \\
\hline 1983 & $18^{(b)}$ & $40^{(b)}$ & 0 & 0 & 1 & 3 \\
\hline 1984 & 97 & 29 & 0 & 0 & 2 & 3 \\
\hline 1985 & 41 & 18 & 0 & 23 & 1 & 2 \\
\hline 1986 & 259 & 13 & 0 & 10 & 4 & 1 \\
\hline 1987 & 468 & 21 & 0 & 11 & 7 & 2 \\
\hline 1988 & 447 & 52 & 0 & 18 & 7 & 5 \\
\hline 1989 & 1344 & 292 & 0 & 11 & 20 & 23 \\
\hline 1990 & 1744 & 234 & 0 & 0 & 26 & 20 \\
\hline 1991 & 1680 & 244 & 0 & 0 & 25 & 20 \\
\hline 1992 & 2021 & 199 & 0 & 0 & 29 & 17 \\
\hline 1993 & 1807 & 228 & 0 & 0 & 27 & 20 \\
\hline 1994 & 1735 & 240 & 0 & 0 & 26 & 21 \\
\hline 1995 & 1990 & 249 & 0 & 0 & 29 & 22 \\
\hline
\end{tabular}

(a) Represents numbers of intra-utility transshipments reported in DOE (1982).

(b) Transshipments to Morris, Illinois storage facility only. Does not include transshipments made with utility-owned spent fuel casks. 
TABLE 6.4. Near-Term Spent Fuel Transportation Hardware Requirements - 50\% Rai1/

50\% Truck Shipping Scenario

Number of

Off-Site

Shipments

Year Truck Rail

1982

1983

1984

1985

1986

1987

1988

1989

1990

1991

$1992 \quad 2526$

$1993 \quad 2383$

1994

1995
0 $29^{(b)}$ $18^{(b)}$
2337

2618
Number of On-Site
Transshipments Truck Rail Iruck Rail
0

0

0

23

10

11

18

11

148

152

159

133

153

161

166
145

160
0

0

0

0

0

0

0

0
0

1

3

2

1

1

13

14

13

13

14

11

14

14

15

(a) Represents numbers of intra-utility transshipments reported in DOE (1982).

(b) Transshipments to Morris, Illinois storage facility only. Does not include transshipments made with utility-owned spent fuel casks. 
Table 6.1 shows the near-term spent fuel cask requirements for the reference scenario. It should be noted that cask requirements for on-site transfers did not significantly impact the total cask requirements. All fractions were increased to the next highest whole number of casks for conservatism. A maximum of 29 truck casks (in 1987, 1992, and 1995) and 22 rail casks (in 1995) are required. The impact of consolidating the fuel is a $50 \%$ reduction in both the number of spent fuel shipments and the annual and maximum annual number of truck and rail casks required (see Table 6.2). Both of these scenarios show a significant increase in spent fuel cask requirments the first year of FRP operation, assumed to be 1987 for these scenarios.

For the delayed reprocessing scenario (See Table 6.3), the large increase in annual cask requirements is delayed until 1989 when the FRP is assumed to begin receiving fuel. The maximum annual cask requirements are the same as the reference scenario, i.e., 29 truck and 22 rail cask systems. This indicates that shipping the required annual amount of spent fuel to the FRP is the controlling factor for these spent fuel management scenarios.

The effect of increasing the amount of spent fuel shipped by truck to $50 \%$ (compared with $25 \%$ by truck in the reference scenario) is the maximum annual requirement for ten additional truck cask systems and seven fewer rail cask systems. The maximum annual requirements for this case are 39 truck systems and 15 rail systems. Capital costs for the maximum annual number of casks required are $\$ 156 \mathrm{M}$ and $\$ 135 \mathrm{M}$ for the reference scenario and 50/50 shipping scenario, respectively. This indicates that a significant capital expenditure savings could be realized by increasing the amount of spent fuel shipped by truck. This is due to the fact that truck shipments can be made more quickly than rail shipments, thus requiring fewer casks to transport equivalent amounts of spent fuel:

The current spent fuel cask fleet includes approximately 22 reference truck cask systems (neglecting the FSV-1 and counting the TN-8 and TN-9 as three reference truck-cask-equivalents) and 6 equivalent rail-cask-systems (counting the NLI-10/24 as 1.5 reference rail-cask-equivalents, although they are not in service at this time). Additional cask requirements as well as an assessment of the undiscounted capital expenditures required to furnish the 
additional number of truck and rail casks is shown in Table 6.5 for each of the spent fuel management scenarios in this study. For the reference scenario, the current cask fleet size is adequate until 1987 when the FRP begins receiving fuel. If consolidated fuel only is shipped, the current truck cask fleet is adequate until at least 1995; however, additional rail casks are required in 1987. If the opening date of the FRP is delayed until 1989, additional casks are not required until that date. In fact, additional truck casks are not required until 1990 for this scenario. The current cask fleet is also adequate until 1987 (opening date of the FRP) for the 50\% truck shipping scenario.

Table 6.5 indicates there are significant economic incentives for increasing the fraction of spent fuel shipped by truck. Undiscounted capital costs indicate that a potential savings of about $\$ 20 \mathrm{M}$ is possible if the fraction of spent fuel shipped by truck is increased from $25 \%$ to $50 \%$. However, the most significant capital cost savings is realized by shipping consolidated fuel only. Table 6.5 shows that only 5 additional rail casks are required for this scenario which results in undiscounted capital expenditures of about \$25M. In fact, this expense could be reduced further because the current truck cask fleet size exceeds the requirements by about 7 -truck cask equivalents. Use of all of the current truck casks would further reduce the demand for rail casks to only one or two additional rail systems. The effect on cask and capital expenditure requirements of delayed reprocessing is minimal in comparison with the reference scenario. Total transportation hardware and undiscounted capital expenditure requirements are the same for this scenario and amount to one more rail cask and about \$5M more than the reference scenario.

Cask requirements for Federal interim storage are as follows. The maximum annual cask requirements for Federal interim storage are 3 rail and 4 truck systems for the reference scenario. These requirements are reduced to 1 rail and 2 truck systems for the consolidated fuel scenario. For the delayed reprocessing scenario, maximums of 5 rail and 7 truck systems are required which reflects the increased amount of spent fuel transported to Federal interim storage in 1987 and 1988. A maximum of 10 rail casks is required to transport the fuel from Federal interim storage to the FRP in the years 1989, 1990 and 1991, assuming all of the fuel contained therein is shipped in rail cask systems. Increasing the fraction of fuel shipped by truck from $25 \%$ to $50 \%$ 
TABLE 6.5. Annual Additional Cask Requirements and Capital Expenditures for Spent Fuel Shipping Systems

\begin{tabular}{|c|c|c|c|c|c|c|c|c|}
\hline \multirow[b]{2}{*}{ Year } & \multicolumn{2}{|c|}{ Reference Scenario } & \multicolumn{2}{|c|}{$\begin{array}{l}\text { Consolidated } \\
\text { Fuel Scenario }\end{array}$} & \multicolumn{2}{|c|}{$\begin{array}{l}\text { Delayed Reprocessing } \\
\text { Scenario }\end{array}$} & \multicolumn{2}{|c|}{$50 \%$ Truck Scenario } \\
\hline & $\begin{array}{l}\text { Additional } \\
\text { Casks } \\
\text { Required (a) } \\
\text { (Truck/Rail) } \\
\end{array}$ & $\begin{array}{l}\text { Capital } \\
\text { Costs } \\
(\$ M) \\
\end{array}$ & $\begin{array}{l}\text { Additional } \\
\text { Casks } \\
\text { Required } \\
\text { (Truck/Rail) } \\
\end{array}$ & $\begin{array}{c}\text { Capital } \\
\text { Costs } \\
(\$ M) \\
\end{array}$ & $\begin{array}{c}\text { Additional } \\
\text { Casks } \\
\text { Required } \\
\text { (Truck/Rail) }\end{array}$ & $\begin{array}{l}\text { Capital } \\
\text { Costs } \\
(\$ M) \\
\end{array}$ & $\begin{array}{c}\text { Additional } \\
\text { Casks } \\
\text { Required } \\
\text { (Truck/Rail) }\end{array}$ & $\begin{array}{l}\text { Capital } \\
\text { Costs } \\
(\$ M) \\
\end{array}$ \\
\hline 1984 & 0 & 0 & 0 & 0 & 0 & 0 & 0 & 0 \\
\hline 1985 & 0 & 0 & 0 & 0 & 0 & 0 & 0 & 0 \\
\hline 1986 & 0 & 0 & 0 & 0 & 0 & 0 & 0 & 0 \\
\hline 1987 & $7 / 12$ & 71.7 & $0 / 3$ & 15.3 & 0 & 0 & $15 / 7$ & 58.2 \\
\hline 1988 & $0 / 2$ & 10.2 & $0 / 1$ & 5.1 & 0 & 0 & $0 / 1$ & 5.1 \\
\hline 1989 & 0 & 0 & 0 & 0 & $0 / 17$ & 86.7 & 0 & 0 \\
\hline 1990 & 0 & 0 & 0 & 0 & $4 / 0$ & 6.0 & 0 & 0 \\
\hline 1991 & 0 & 0 & 0 & 0 & 0 & 0 & 0 & 0 \\
\hline 1992 & 0 & 0 & 0 & 0 & $3 / 0$ & 4.5 & 0 & 0 \\
\hline 1993 & 0 & 0 & 0 & 0 & 0 & 0 & 0 & 0 \\
\hline 1994 & $0 / 1$ & 5.1 & $0 / 1$ & 0 & 0 & 0 & 0 & 0 \\
\hline 1995 & $0 / 1$ & 5.1 & 0 & 0 & 0 & 0 & $2 / 1$ & $8 / 1$ \\
\hline TOTAL & $7 / 16$ & 92.1 & $0 / 5$ & 25.5 & $7 / 17$ & 97.2 & $17 / 9$ & 71.4 \\
\hline
\end{tabular}

(a) These values represent the number of additional truck/rail casks required to provide the spent fuel transportation services in this study.

(b) Capital costs for truck and rail spent fue 1 cask systems are $\$ 1.5 \mathrm{M}$ and $\$ 5.1$ mid-1982 dollars, respectively (see Section 5.3 ). 
changes the maximum annual cask requirements for Federal interim storage to 2 rail casks and 4 truck casks. This illustrates that the receiving requirements for Federal interim storage can be accommodated with 1 less rail cask and the same number of truck casks if the shipping mode split is increased to $50 \%$ compared with $25 \%$ truck shipments in the reference scenario.

The maximum annual spent fuel shipping cask requirements for the FRP ( 1500 MTU/yr capacity) in the reference scenario are approximately 29 truck casks and 22 rail casks (25\% of the spent fuel assemblies are shipped in truck casks for this scenario). As expected, cask requirements are reduced by a factor of two for the consolidated fuel shipping scenario and are essentially equal for the delayed reprocessing scenario. However, for the $50 \%$ truck shipping scenario, a maximum of 15 rail casks and 39 truck casks are required to deliver spent fuel to the FRP at the design processing rate of 1500 MTU/yr. This is 7 fewer rail casks and 10 more truck casks than the reference scenario requires. At this time, the receiving facilities at the Barnwell Nuclear Fuels Plant are not designed for receiving $50 \%$ of their spent fuel in truck casks but they could be modified to do so if a significant cost savings results from receiving a larger fraction of fuel by truck.

\subsection{RESULTS OF THE SPENT FUEL TRANSPORTATION COST ANALYSIS}

This section presents the results of the spent fuel transportation cost analysis performed in this study. The undiscounted truck and rail transportation costs for each of the spent fuel management scenarios considered in this study are shown in Table 6.6. It should be noted that the costs of onsite transshipments are not included in the totals. However, the costs for the spent fuel transportation campaigns from the San Onofre and Cooper Nuclear Stations to the Morris, Illinois storage facility (DOE 1982) are included in the totals.

Transportation costs for all spent fuel shipments are shown in Table 6.6 . They reach a steady-state after the FRP begins receiving fuel in each scenario. Therefore, the costs for the several years after the opening of the 
TABLE 6.6. Spent Fue1 Transportation Costs

for the Reference Spent Fuel

Management Scenario and Sensitivity

Cases in this Study

\begin{tabular}{|c|c|c|c|c|c|c|c|c|}
\hline \multirow[b]{2}{*}{ Year } & \multicolumn{2}{|c|}{$\begin{array}{l}\text { Reference } \\
\text { Scenario }\end{array}$} & \multicolumn{2}{|c|}{$\begin{array}{l}\text { Consol idated } \\
\text { Fuel Scenario }\end{array}$} & \multicolumn{2}{|c|}{$\begin{array}{c}\text { Delayed } \\
\text { Reprocessing } \\
\text { Scenario } \\
\end{array}$} & \multicolumn{2}{|c|}{$\begin{array}{l}50 \% \text { Truck } \\
\text { Scenario }\end{array}$} \\
\hline & Truck & Rail & Truck & Rail & Truck & Rail & Truck & Rail \\
\hline $982^{(c)}$ & 0 & 2.99 & 0 & 1.50 & 0 & 2.99 & 0 & 2.99 \\
\hline $1983^{(c)}$ & 0.44 & 4.53 & 0.22 & 2.27 & 0.44 & 4.53 & 0.44 & 4.53 \\
\hline 984 & 1.23 & 3.37 & 0.61 & 1.69 & 1.23 & 3.37 & 2.16 & 2.25 \\
\hline 985 & 0.54 & 2.02 & 0.27 & 1.01 & 0.54 & 2.02 & 1.11 & 1.35 \\
\hline 986 & 3.32 & 1.57 & 1.66 & 0.78 & 3.32 & 1.57 & 3.81 & 1.03 \\
\hline 1987 & 30.42 & 27.66 & 15.21 & 13.83 & 6.84 & 2.82 & 38.36 & 19.35 \\
\hline 1988 & 28.70 & 30.75 & 14.35 & 15.38 & 6.59 & 6.82 & 37.51 & 21.40 \\
\hline 1989 & 29.42 & 27.73 & 14.71 & 13.86 & 20.09 & 35.85 & 37.43 & 19.39 \\
\hline 1990 & 28.82 & 29.21 & 14.41 & 1 & 26.63 & 30.89 & 37.29 & 20.36 \\
\hline 991 & 27.91 & 30.17 & 13.95 & 15.09 & 25.7 & 31.74 & 36.65 & 21.00 \\
\hline 1992 & 30.44 & 26.55 & 15.22 & 13.27 & 30.50 & 26.42 & 38.95 & 17.71 \\
\hline 1993 & 27.90 & 31.14 & 13.95 & 15.57 & 27.93 & 31.03 & 37.45 & 20.83 \\
\hline 1994 & 26.84 & 33.19 & 13.42 & 16.60 & 26.85 & 33.17 & 37.10 & 22.16 \\
\hline 1995 & 30.14 & 34.04 & 15.07 & 17.02 & 30.14 & 34.04 & 40.43 & 22.72 \\
\hline
\end{tabular}

(a) Does not include costs for on-site intra-utility transshipments.

(b) Numbers contain excess significant figures for cons istency.

(c) Represents costs for spent fuel transshipments to Morris, Illinois storage facility shown in DOE (1982). 
FRP can be used for comparison between scenarios. For the reference scenario, the total truck plus rail transportation costs for the steady-state years (19871995) average about $\$ 59 \mathrm{M} / \mathrm{yr}$. These average costs are about $\$ 30 \mathrm{M} / \mathrm{yr}$ for the consolidated fuel shipping scenario and $\$ 58.5 \mathrm{M} / \mathrm{yr}$ for the $50 \%$ truck shipping scenario. The average annual transportation costs for the steady-state reprocessing years in the delayed reprocessing scenario (1989-1995) are $\$ 59 \mathrm{M} / \mathrm{yr}$. This information indicates there is a significant economic advantage to shipping consolidated fuel or alternatively to designing a new generation of shipping casks for older fuel (assumed to be equivalent cases). This also illustrates that a very small annual savings is realized by increasing the fraction of spent fuel shipped by truck from $25 \%$ to $50 \%$. Further savings could be realized by increasing the truck fraction to higher levels.

It is interesting to compare the transportation costs associated with Federal interim storage for the reference, delayed reprocessing and $50 \%$ truck shipping scenarios as shown in Table 6.7. The total transportation costs for incoming spent fuel shipments in the reference scenario are $\$ 12.1 M$ (truck plus rail costs) compared to $\$ 34 M$ and $\$ 11.7 M$ for the delayed reprocessing and $50 \%$ trucking scenarios, respectively. Therefore, a three-fold increase in transportation costs for incoming spent fuel shipments to Federal interim storage facility results if reprocessing is delayed until 1989. This reflects the increased amount of spent fuel shipped to Federal interim storage in this scenario. A small decrease in transportation costs for incoming shipments results if the truck/rail shipping fraction is increased to $50 \%$ truck from $25 \%$ truck in the reference scenario.

Transportation costs associated with removing spent fuel from Federalinterim storage are $\$ 13.1 \mathrm{M}$ for the reference and $50 \%$ truck shipping scenarios, assuming all out-going shipments are done in rail casks. This is increased to $\$ 34 M$ for the delayed reprocessing scenario again reflecting the increased amount of spent fuel shipped to Federal interim storage in this scenario.

The total costs associated with transportation of spent fuel to/from the TEF are the same for each scenario except the consolidated fuel shipping scenario. The transportation costs for the reference, delayed reprocessing, 
TABLE 6.7. Annual Transportation Costs Associated with the Federal Interim Storaqe

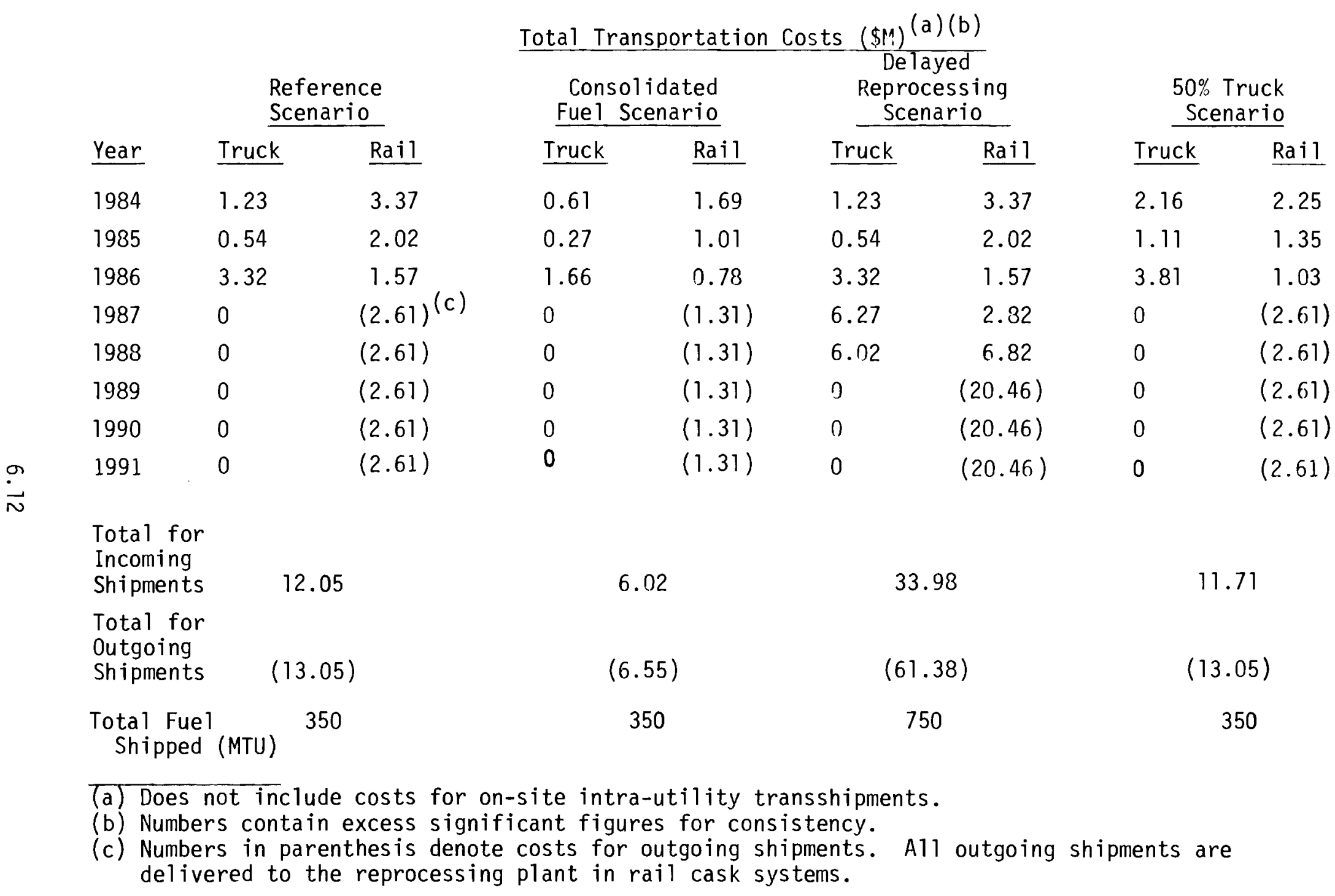


and $50 \%$ truck shipping scenario are $\$ 2.5 \mathrm{M}$, and for the consolidated fuel shipping scenario are $\$ 1.2 M$. As indicated previously in this report, all shipments to and from the TEF are performed in truck systems.

The annual transportation costs associated with the FRP are considerably higher than the costs reported above for the TEF and for Federal interim storage. The average annual spent fuel transportation costs associated with the FRP in the reference scenario are about $\$ 58.9 \mathrm{M} / \mathrm{yr}$. This compares with about $\$ 29.4 \mathrm{M} / \mathrm{yr}$ in the consolidated fuel shipping scenario to $\$ 58.3 \mathrm{M} / \mathrm{yr}$ in the $50 \%$ truck shipping scenario. This indicates that a $50 \%$ reduction in transportation costs could be realized by shipping only consolidated fuel to the FRP, while a relatively insignificant costs savings results from increasing the truck shipping fraction. It is not known at this time what the impacts on the reprocessing facility are for these alternatives. 



\subsection{CONCLUSIONS AND RECOMMENDATIONS}

The impacts of various spent fuel management strategies on spent fuel transportation hardware requirements and transportation costs were examined in this study. A reference spent fuel management scenario was developed and the associated cask fleet requirements and transportation costs were determined using a computer modeling technique. In addition, sensitivity cases reflecting increased cask capacities due to consolidating spent fuel (or alternatively due to a new generation of spent fuel shipping casks), delaying the opening of a fuel reprocessing plant, and increasing the amount of spent fuel shipped by truck were analyzed and compared with the reference scenario to determine their effects on cask requirements and transportation costs. Conclusions related to optimization of the transportation study can be drawn from the results in this study. These conclusions are discussed in this section as well as the recommendations for further work that were recognized during the course of this analysis. The conclusions from this study can be affected by changing the given set of assumptions used in this analysis.

There are significant economic advantages to shipping consolidated fuel. This conclusion can also be applied to the operational costs of a new generation of spent fuel shipping casks designed to transport longer-cooled fuel than the current generation of casks. In each case, the cask capacities can be up to twice the capacities of the current generation of casks. Transportation hardware requirements and costs are reduced by up to a factor of 2 for each of these cases. Further refinement of the information developed for this study could include a more detailed treatment of a consolidated fuel shipping scenario or a scenario using a new generation of casks. The assessment presented in this study could be improved to include refined shipping parameters and transportation unit costs for this scenario. It is recommended that consolidated fuel shipping technology be 1 icensed if fuel consolidation costs do not negate savings.

Increasing the fraction of spent fuel shipped by truck reduces capital cost expenditures for additional spent fuel shipping systems. This is because truck systems are able to complete shipments much faster than rail systems, thus requiring a cask fleet that costs less to transport the same amount of 
spent fuel. In addition, total transportation costs (truck plus rail) are reduced by a small amount when increasing the fraction shipped by truck from $25 \%$ to $50 \%$. Future work in this area that would be useful includes increasing the truck fraction to even higher levels to determine whether a larger transportation cost savings is realized for the higher truck shipping fractions. The model developed for this study could be refined to include capital cost estimates for additional truck handling facilities that may be needed.

One of the objectives of this study was to determine if the current cask fleet size is adequate to perform the required transportation services. It was found that, in general, the current cask fleet is large enough until the year that an FRP is scheduled to begin receiving fuel. The presence of an FRP initiates the demand on spent fuel transportation hardware in a mature fuel cycle.

A delay of two years in the implementation of the first reprocessing facility results in a significant increase in the total amount of fuel shipped to/from Federal interim storage. This obviously increases the transportation costs associated with this case. Further work concerning Federal interim storage could include an assessment of shipping fuel to or from the system in storage casks, assuming they can be licensed for over-the-road transportation.

Additional studies could refine transportation cost estimates. Impacts of spent fuel consolidation equipment location and an assessment of legal-weight versus over-weight truck shipping are significant. In order to determine if it is cost-effective to transport consolidated fuel, it is necessary to study the equipment, construction, and operating costs of fuel consolidation facilities. Consolidation facilities may be located either at individual reactors or at centralized packaging facilities for many reactors. An economic comparison of the two truck shipping modes would include a state-by-state assessment of the costs for required over-weight truck permits and the administrative efforts involved to obtain such permits. It is not known at this time if the increased cargo capacities associated with overweight truck systems overcomes the cost disadvantages of the permit process and administrative efforts. It is felt that utility companies and cask supplier companies would benefit from these two studies. 


\section{REFERENCES}

Allied-General Nuclear Services (AGNS). 1980. Scoping Studies of the Alternative Options for Defueling, Packaging, Shipping and Disposing of the TMI-2 Spent Fuel Core. AGNS-35900-1.5-79, Barnwe11, South Carolina.

Carr, W.H. 1982. Estimation of Nuclear Waste Types, Characteristics, and Quantities for the Barnwell Nuclear Fuel Plant. ONWI/3092/TOP-01, AlliedGeneral Nuclear Services, Barnwell, South Carolina.

Cole., B.M., R.E. Cross, A.L. Franklin, and E.F. Votaw, 1982. Truck, Rail, and Heavy Haul Charges for Shipping LWR Spent Fuel. PNL-4064, TTC-0259, Pacific Northwest Laboratory, Richland, Washington

Court Decision: The Akron, Canton, and Youngstown Railroad Company versus the Interstate Commerce Commission. 1980. 611 F. 2d 1162 (6th Cir. 1979), Cert denied, 49 U.S. Law Week 3246.

Elder, H.K., et al. 1978. An Assessment of the Risk of Transporting Spent Nuclear Fuel by Truck. PNL-2588, Pacific Northwest Laboratory, Richland, Washington.

Elder, H.K., et al. 1981. An Analysis of the Risk of Transporting Spent Nuclear Fuel by Train. PNL-2682, TTC-0145, Pacific Northwest Laboratory, Richland, Washington.

Lambert, R.W., C.E. King, and T.E. Tehan. 1981. Comparative Evaluation of Wet and Dry Unloading of Spent Fuel Shipping Casks. NEDG-24905, TTC-0203, General Electric Co., San Jose, California.

Nuclear Assurance Corp. (NAC). 1981. NAC Presentation to Electric Utility Companies' Nuclear Transportation Group on Nuclear Assurance Corporation's Spent Nuclear Fuel Shipping Cask Program, Atlanta, Georgía.

Shirley, C.G., E.L. Wilmot, E.W. Shepherd. 1981. Operational and Regulatory Impacts of Regional Management on Transportation of Commercial Low-Level Radioactive Waste. SAND 81-1509, TTC-0028, Transportation Technology Center, Sandia National Laboratories, Albuquerque, New Mexico.

Tri-State Motor Transit Co. 1981. Docket No. MC-109397 and Subs Naming Specific Truckload Commodity Rates and Mileage Truckload Commodity Rates Applying on Radioactive Materials, Related Articles Classified or Declared Sensitive by the United States Government, Hazardous Waste, and Empty Radioactive Material Containers, Joplin, Missouri.

U.S. Code of Federal Regulations, Title 10, Part 73 "Physical Protection of Plants and Materials". 
U.S. Department of Energy (DOE). 1979. Technology for Commercial Radioactive Waste Management. DOE/ET-0028 prepared for DOE - Office of NucTear Waste Management, Washington, D.C.

U.S. Department of Energy (DOE). 1981. A Preliminary Assessment of Alternative Dry Storage Methods for the Storage of Commercial Spent Nuclear Fue1. D0E/ET-47929-1 prepared by E.R. Johnson Associates, Inc., Reston, Virginia.

U.S. Department of Energy (DOE). 1982. Spent Fuel Storage Requirements Update of DOE/SR-0007, DOE/RL-82-1 prepared for U.S. D0E/Richland Operations office, Richland, Washington. 
APPENDIX A

QUANTITIES OF LWR

SPENT FUEL

REQUIRING TRANSPORTATION

SERVICES IN THE

NEAR FUTURE 
APPENDIX A

QUANTITIES OF LWR SPENT FUEL REQUIRING TRANSPORTATION SERVICES

IN THE NEAR FUTURE

This appendix discusses the quantities of commercial LWR spent fuel that will be transported in the near future. The bases and assumptions that were made to facilitate the computer modeling process used in this study are also discussed. Separate subsections are provided for each source of spent fuel that will be shipped in the near future, i.e., until the early 1990's. Tables A.1 and A.2 summarize the annual receipt rates of spent fuel at each facility in this study for the scenarios previously discussed.

\section{A.1 LWRS WITH NEAR-TERM STORAGE PROBLEMS}

Delays in the development of U.S. reprocessing and spent fuel disposal capabilities have caused a lack of adequate spent fuel storage capacity at commercial nuclear electric generating stations. This has resulted in many nuclear power plants being faced with the possibility of shutdown. The U.S. Congress is currently considering legislation that would require the DOE to provide Federal interim storage for temporary relief storage of spent fuel to prevent shutdown of affected power reactors. Although the government will provide Federal interim storage for commercial spent fuel, it will provide storage only as needed to prevent power plant shutdowns. The ultimate responsibility for spent fuel management rests with the utilities. The interim relief storage is also assumed to be unlicensed dry storage in metal casks at a government site. The utilities are assumed to retain title to the stored spent fue 1 .

As indicated in Section 3.1, Federal interim storage is assumed in the reference scenario to begin receiving spent fuel in 1984 and will receive and store fuel until 1987. After 1987, LWRs with inadequate spent fuel storage capacity are assumed to have first priority in shipping their fuel discharges to the FRP, which is assumed to open in that year. For the reference spent fuel management scenario, a total of 93 MTU of spent fuel will be shipped to Federal interim storage from these reactors, assuming maximum at-reactor 
TABLE A.l Summary of Annual Spent Fuel Receipt Rates For Destination

Facilities - Reference, Consolidated Fuel and 50\% Truck Shipping Scenarios

Annual Receipts of Spent Fuel at Spent Fuel Origin (Percent

$\frac{\text { Destination Facilities. (MTU/yr) }}{\text { FueT }} \frac{\text { of Annual Receipt Rate)(a) }}{\text { FueT }}$

\begin{tabular}{|c|c|c|c|c|c|}
\hline Year & $\begin{array}{l}\text { Interim } \\
\text { Storage }\end{array}$ & TEF & $\begin{array}{c}\text { Reprocessing } \\
\text { Plant } \\
\end{array}$ & $\begin{array}{l}\text { Interim } \\
\text { Storage } \\
\end{array}$ & $\begin{array}{c}\text { Reprocessing } \\
\text { Plant }\end{array}$ \\
\hline 194 & 96.4 & 0 & $\overline{0}$ & $\begin{array}{l}\text { USP }-14^{(b)} \\
\text { WV }-58 \\
\text { THI }-28\end{array}$ & $N A^{l}$ \\
\hline 1985 & 83.4 & 0 & 0 & $\begin{array}{l}\text { USP }-0 \\
\text { IVV }-68 \\
\text { THI }-32\end{array}$ & NA \\
\hline 1986 & 163.4 & 0 & 0 & $\begin{array}{r}\text { USP }-27 \\
\text { WV }-49 \\
\text { TMI }-24\end{array}$ & NA \\
\hline 1987 & $-68.6^{(d)}$ & 11.0 & 1500 & (e) & $\begin{array}{c}\text { FIS }-5 \\
\text { USP }-11 \\
\text { UNSP-84 }\end{array}$ \\
\hline 1988 & -68.6 & 11.0 & 1500 & & $\begin{array}{c}\text { FIS }-5 \\
\text { USP }-16 \\
\text { UNSP -79 }\end{array}$ \\
\hline 1989 & -68.6 & 0 & 1500 & & $\begin{array}{l}\text { FIS }-5 \\
\text { USP }-32 \\
\text { UNSP-63 }\end{array}$ \\
\hline 1990 & -68.6 & 0 & 1500 & & $\begin{array}{c}\text { FIS }-5 \\
\text { UPS }-30 \\
\text { UNSP-65 }\end{array}$ \\
\hline 1991 & -68.6 & 0 & 1500 & & $\begin{array}{c}\text { FIS }-5 \\
\text { USP }-35 \\
\text { UNSP }-60\end{array}$ \\
\hline 1992 & 0 & 0 & 1500 & & $\begin{array}{r}\text { USP }-45 \\
\text { UNSP }-55\end{array}$ \\
\hline 1993 & 0 & -11.0 & 1500 & & $\begin{array}{l}\text { USP }-46 \\
\text { UNSP }-54 \\
\text { TEF }-0.4\end{array}$ \\
\hline $1994^{(f)}$ & 0 & -11.0 & 1500 & & $\begin{array}{l}\text { USP }-68 \\
\text { UNSP }-31 \\
\text { TEF }-0.4\end{array}$ \\
\hline
\end{tabular}

(a) The TEF is assumed to receive $100 \%$ of its spent fuel from an unspecified LWR not currentiy experiencing on-site storage difficulties.

(b) Abbreviations are as follows: $\frac{\text { USP }}{=}$ utilities with storage problems; UNSP = utilities with no störage problems; W.V. = West Valley; TMI $=$ Three Mile Is 1 and; FIS $=$ Federal interim storage; TEF = Test and Evaluation Facilfty.

(c) $\overline{N A}=$ Not Applicable.

(d) Negative number denotes out-going shipments.

(e) It is not known at this time in what order fuel will be removed from Federal interim storage.

(f) This is the final year under consideration in this study. 
TABLE A.2 Sumary of Annual Receipt Rates For Destination Facilities Delayed Reprocessing Scenario.

Annual Receipts of Spent Fuel at Spent Fuel Origin (Percent Destir.ation Facilities (ITU/yr) of Annual Receipt Rate)(a)

\begin{tabular}{|c|c|c|c|c|c|}
\hline \multirow[b]{2}{*}{ Year } & \multicolumn{3}{|c|}{$\begin{array}{l}\text { Annual Receipts of Spent Fuel at } \\
\text { Destiration Facilities (ITU/yr) }\end{array}$} & \multicolumn{2}{|c|}{$\begin{array}{l}\text { Spent Fuel Origin (Percent } \\
\text { of Annual Receipt Rate) (a) }\end{array}$} \\
\hline & $\begin{array}{l}\text { Interim } \\
\text { Storage } \\
\end{array}$ & TEF & $\begin{array}{c}\text { Fuel } \\
\text { Reprocessing } \\
\text { Plant } \\
\end{array}$ & $\begin{array}{l}\text { Interim } \\
\text { Storage } \\
\end{array}$ & $\begin{array}{c}\text { Fuel } \\
\text { Reprocessing } \\
\text { Plant } \\
\end{array}$ \\
\hline 1984 & 96.4 & 0 & 0 & $\begin{array}{l}\text { USP }-14(b) \\
W V-58 \\
\text { TMI }-28\end{array}$ & $N A(c)$ \\
\hline 1985 & 83.4 & 0 & 0 & $\begin{array}{l}\text { USP }-0 \\
\text { WV }-68 \\
\text { TMI }-32\end{array}$ & NA \\
\hline 1986 & 163.4 & 0 & 0 & $\begin{array}{r}\text { USP }-27 \\
\text { WV }-49 \\
\text { TMI }-24\end{array}$ & NA \\
\hline 1987 & 167 & 11.0 & 0 & USP-100 & $N A$ \\
\hline 1988 & 238 & 11.0 & 0 & USP-100 & NA \\
\hline 1989 & $-249.4^{(d)}$ & 0 & 1500 & (e) & $\begin{array}{r}\text { FIS }-17 \\
\text { USP }-31 \\
\text { UNSP }-52\end{array}$ \\
\hline 1990 & -249.4 & 0 & 1500 & & $\begin{array}{r}\text { F IS }-17 \\
\text { USP }-30 \\
\text { UNSP }-53\end{array}$ \\
\hline 1991 & -249.4 & 0 & 1500 & & $\begin{array}{r}\text { F IS }-17 \\
\text { USP }-35 \\
\text { UNSP }-48\end{array}$ \\
\hline 1992 & 0 & & 1500 & & $\begin{array}{r}\text { USP }-45 \\
\text { UNSP }-55\end{array}$ \\
\hline 1993 & 0 & -11.0 & 1500 & & $\begin{array}{l}\text { USP }-46 \\
\text { UNSP }-54 \\
\text { TEF- } 0.4\end{array}$ \\
\hline 1994 & $o(f)$ & -11.0 & 1500 & & $\begin{array}{l}\text { USP }-68 \\
\text { UNSP - 31 } \\
\text { TEF- } 0.4\end{array}$ \\
\hline
\end{tabular}

(a) The TEF is assumed to receive $100 \%$ of its spent fuel from an unspecified LWR not currently experiencing on-site storage difficulties.

(b) For definition of abbreviations, see Table 3.1.

(c) $N A=$ Not Applicable.

(d) Negative number denotes out-going shipment.

(e) It is not known at this time in what order fuel will be removed from Federal interim storage.

(f) This is the final year under consideration in this study. 
storage capacity is installed at reactors (DOE 1982). All of this fuel will originate from pressurized water reactors (PWRs) including the Surry-1 and 2 (Virginia Electric Power Co.), Palisades (Consumers Power Co.), St. Lucie-1 (Florida Power and Light Co.), and Trojan (Portland General Electric Co.) nuclear power stations. For the delayed reprocessing scenario, Federal interim storage will extend their receiving and storage operations until 1989, the delayed opening date of BNFP. This increases the amount of fuel shipped to interim relief storage from these sources to 497 MTU. The reactors shipping spent fuel for interim storage will include the aforementioned PWRs plus Robinson-2 (Carolina Power and Light Co.), Oconee-1 and 2 (Duke Power Co.), and Turkey Point-3 (Florida Power and Light Co.), all PWRs, plus Brunswick-1 (Carolina Power and Light Co.), LaSalle-1 and 2 (Commonwealth Edison Co.), Monticel10 (Northern States Power Co.), Fitzpatrick (Power Authority of the State of New York) and Peach Bottom-2 and 3 (Philadelphia Gas and Electric Co.), all boiling water reactors (BWRs). The total number of fuel assemblies that are assumed to be shipped to Federal interim storage from these reactors in the reference scenario is 207 , all of them from PWRs. A total of 712 PWR and 1026 BWR assemblies is assumed to be shipped to Federal interim storage from these reactors in the delayed reprocessing scenario. This data is shown for information purposes only. The computer model described in section 3.2 uses actual reactor discharge projections contained in the spent fuel data base (DOE 1982).

\section{A.2 LWRS WITH NO NEAR-TERM STORAGE PROBLEMS}

The commercial power reactors that have adequate on-site spent fuel storage capacity are assumed to continue storing their entire discharge quantity until the FRP opens in 1987 (reference scenario) or 1989 (delayed reprocessing scenario). These reactors are assumed to provide the balance of the $1500 \mathrm{MTU} / \mathrm{yr}$ reprocessing capacity of the FRP after all other facilities have shipped their annual requirements. In addition, the TEF will receive spent fuel from an unspecified LWR that has adequate on-site storage capacity.

It is important to recognize that some of the reactors in this category will lose FCR capability in their storage basins at some time after Federal interim storage stops receiving fuel. These reactors are identified using the 
spent fuel data base (DOE 1982) and placed on the list of reactors having first priority for shipping spent fuel to BNFP.

The disposal demonstration TEF is assumed to receive and emplace spent fuel as a secondary waste form for demonstration purposes (defense high-level waste is assumed to be the primary waste form). Therefore, a total of 48 PWR assemblies is assumed to be shipped to the TEF packaging facility (assumed to be collocated with the TEF demonstration disposal facility) from an unspecified PWR. The one-way shipping distance is assumed to be $4000 \mathrm{~km}$ (2500 mi.) for conservatism. Half of the fuel assemblies will be shipped in the first year of TEF operation (assumed to be 1987) and the balance in the second year.

\section{A.3 WESTERN NEW YORK NUCLEAR SERVICE CENTER (WEST VALLEY)}

The state of New York has indicated that they would like the spent fuel in the West Valley storage basin to be removed as soon as possible. For this study, it was assumed that these shipments will begin in 1984 and will continue in a levelized manner until 1987. These fuel assemblies are assumed to be shipped to Federal interim storage, although this may eventually not be the case. The current inventory of the West Valley fuel storage pool is 515 BWR and 235 PWR assemblies that contain a total of about 169 MTU (DOE 1982). This fuel will be shipped at a rate of one-third of the current inventory in each of the years 1984,1985 , and 1986 for all scenarios.

\section{A.4 THREE MILE ISLAND (TMI) NUCLEAR STATION}

The disposition of the damaged TMI reactor core was discussed in a report prepared by Allied-General Nuclear Services (AGNS 1980). AGNS researchers estimated that about 200 canisters of fuel assemblies and core debris will be required to contain the entire damaged core. For this study, it is assumed that the canisters will have roughly the same dimensions as the PWR fuel assemblies and, therefore, can be shipped in much the same manner as intact fuel assemblies, i.e., 1 canister can be shipped in a truck cask and 7 canisters can be shipped in a rail cask. These shipments are assumed to commence in 1984 and one-third of the total is assumed to be shipped to the interim storage facility in each of the years 1984, 1985, and 1986 for all of the scenarios. 


\section{A.5 FEDERAL INTERIM STORAGE}

Federal interim storage is assumed to receive and store for a short period of time the spent fuel elements from reactors with near-term storage problems and from West Valley and spent fuel canisters from TMI. These in-coming shipments will begin in 1984 and continue until 1987 for the reference scenario and until 1989 for the delayed reprocessing scenario. In all scenarios, incoming shipments to Federal interim storage are terminated as soon as the FRP begins receiving spent fuel. At that time, Federal interim storage is assumed to begin shipping the spent fuel contained therein to the FRP. Shipping to the FRP is assumed to be accomplished in a levelized manner until the year 1991 for both scenarios. The resulting shipping-out rate for the reference scenario is about $70 \mathrm{MTU} / \mathrm{yr}$ and for the delayed reprocessing scenario is about $250 \mathrm{MTU} / \mathrm{yr}$.

\section{A.6 TEST AND EVALUATION FACILITY (TEF)}

The TEF is assumed to receive and demonstrate disposal of 48 PWR fuel assemblies as well as commercial and defense high-level wastes. It is further assumed that the fuel assemblies will be retrieved from the TEF and shipped to BNFP for reprocessing after the demonstration is completed. The demonstration is assumed to be completed in 1993 and retrieval and shipping operations are assumed to be completed by 1994. Therefore, 24 PWR assemblies will be shipped from the TEF to BNFP in each of the years 1993 and 1994. 


\title{
REFERENCES FOR APPENDIX
}

\begin{abstract}
Allied-General Nuclear Services, Inc. (AGNS). 1980. Scoping Studies of Alternative Options for Defueling, Packaging, Shipping, and Disposing of the TMI-2 Spent Fuel Core. AGNS-35900-1.5-79, Barnwel1, South Carolina.

U.S. Department of Energy (DOE) . 1982. Spent Fuel Storage Requirements Update of DOE/SR-007. DOE/RL-82-1, prepared for U.S. DOE/Richland Operations Office, Richland, Washington.
\end{abstract}





\section{APPENDIX B}

\section{INPUT REQUIREMENTS \\ FOR THE \\ SPENT FUEL \\ TRANSPORTATION SYSTEM \\ MODEL}




\section{APPENDIX B}

\section{INPUT REQUIREMENTS FOR THE SPENT FUEL TRANSPORTATION SYSTEM MODEL}

The spent fuel transportation system model developed for this study is written in FORTRAN and is installed on the UNIVAC 1110 computer at DOE-RL. This appendix contains descriptions of the input requirements for the spent fuel transportation system model. This discussion is intended to facilitate use of the model by persons who are familiar with computer modeling techniques. Therefore, many words and terms that are meaningful to persons familiar with FORTRAN modeling techniques but not to the lay-man are not defined and discussed. For further information of this type the reader is directed to a FORTRAN users manual.

Three sets of input data are required by the model. The first set is the spent fuel discharge file which is created from the Commercial spent Fuel Management Program's spent fuel discharge data base. It is input on logical unit 22. The second set of input data is the case control parameters and is read on logical unit 5 . It consists of 1 case title card and the FORTRAN namelist CONTRL. The final set of data is a set of region specifications and is also read on unit 5 . These data sets are described below.

\section{B.1 Data Set 1: Spent Fuel Discharge File}

This file consists of card images and includes reactor descriptions and spent fuel discharge information. Each reactor has been assigned a reactor ID code. This code is used in all data sets. The list of reactor codes is shown in Table B.1. There are two cards describing each reactor plus one card for each discharge projected for the reactor. The formats for these cards are shown below; I designates integer numeric field, $F$ designates numeric field with a decimal point and $A$ designated alpha numeric information. 
TABLE B.1. Reactor Listing

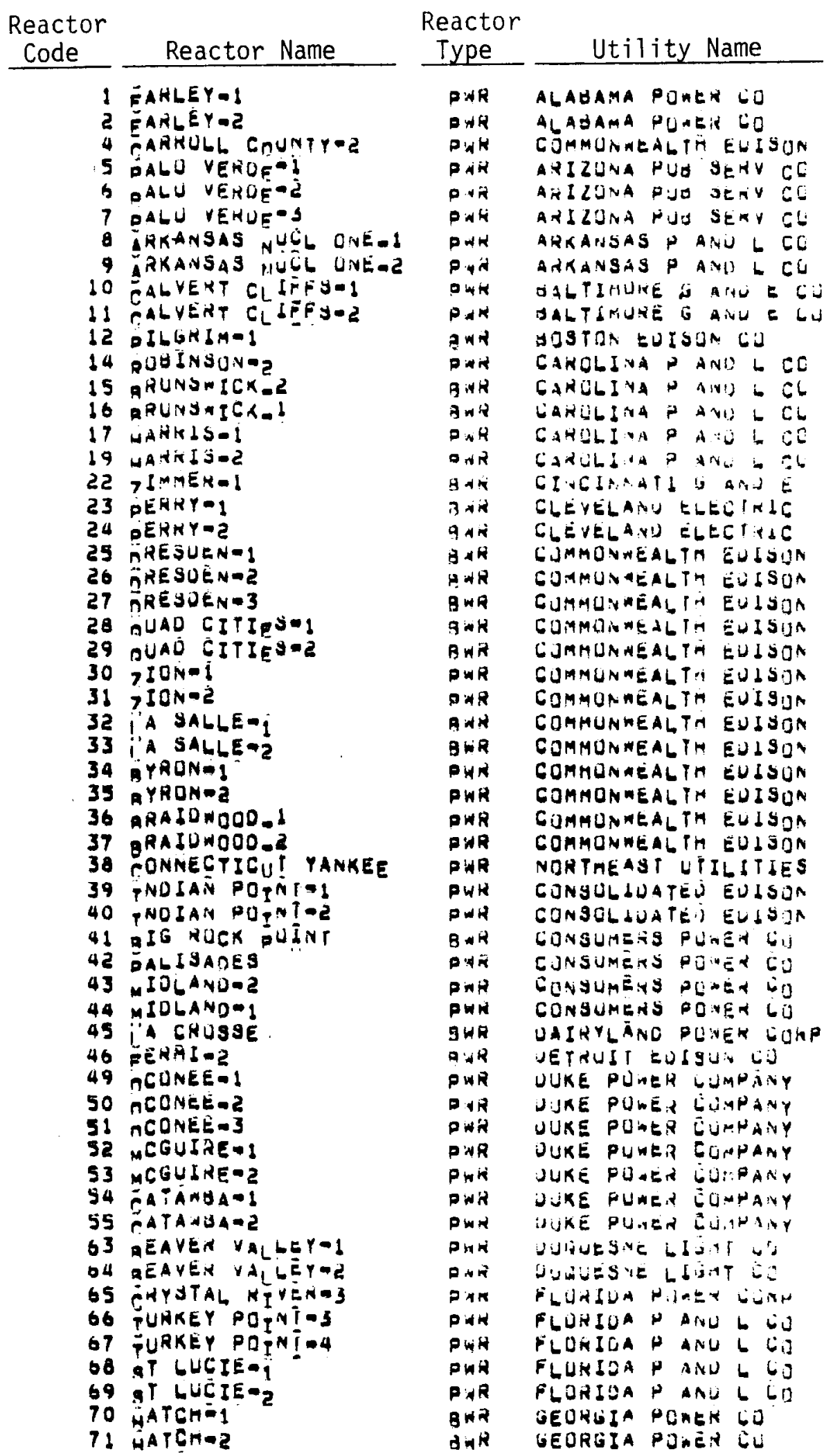


TABLE B.1. (Continued)

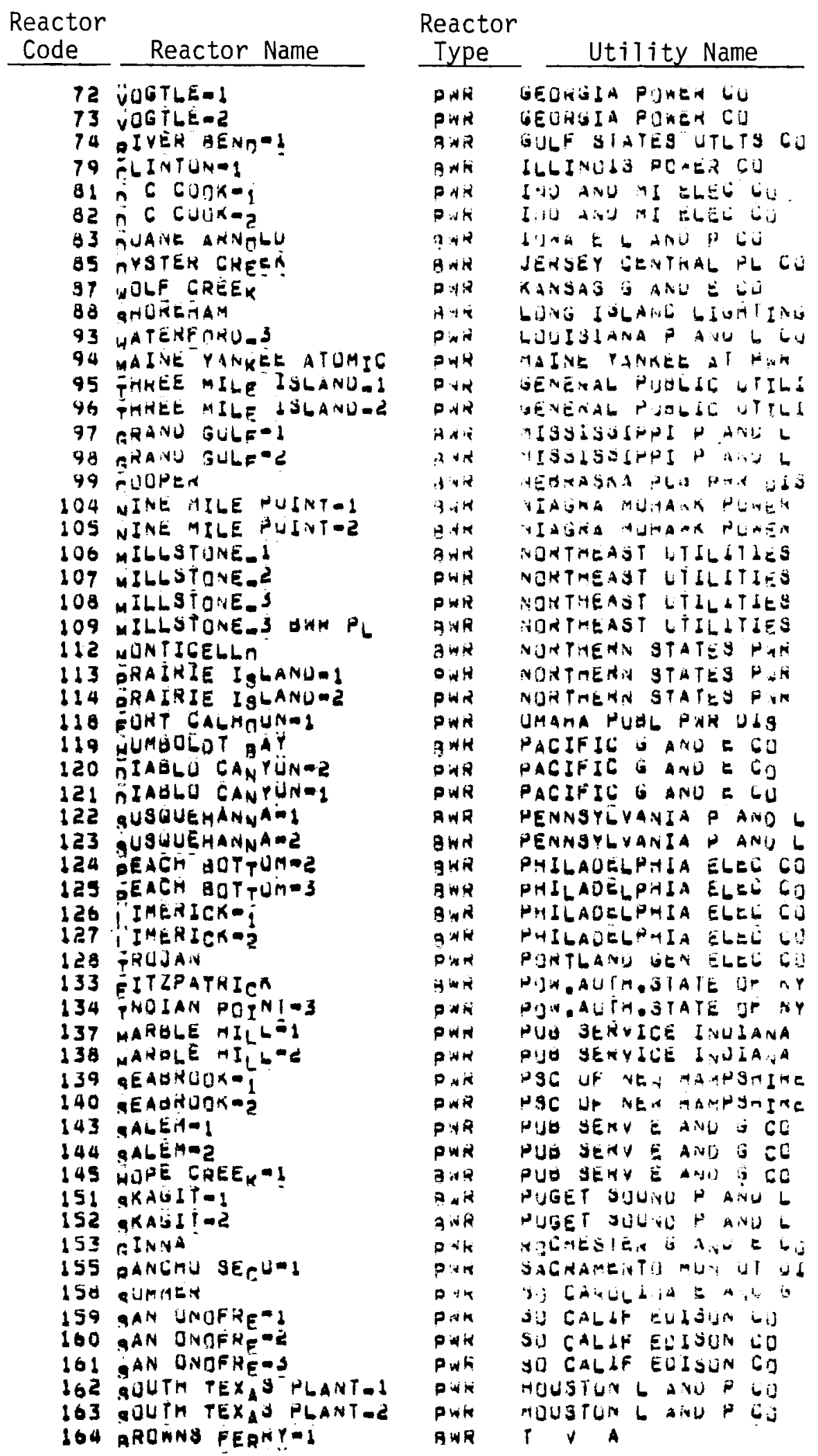




\section{TABLE B.1. (Continued)}

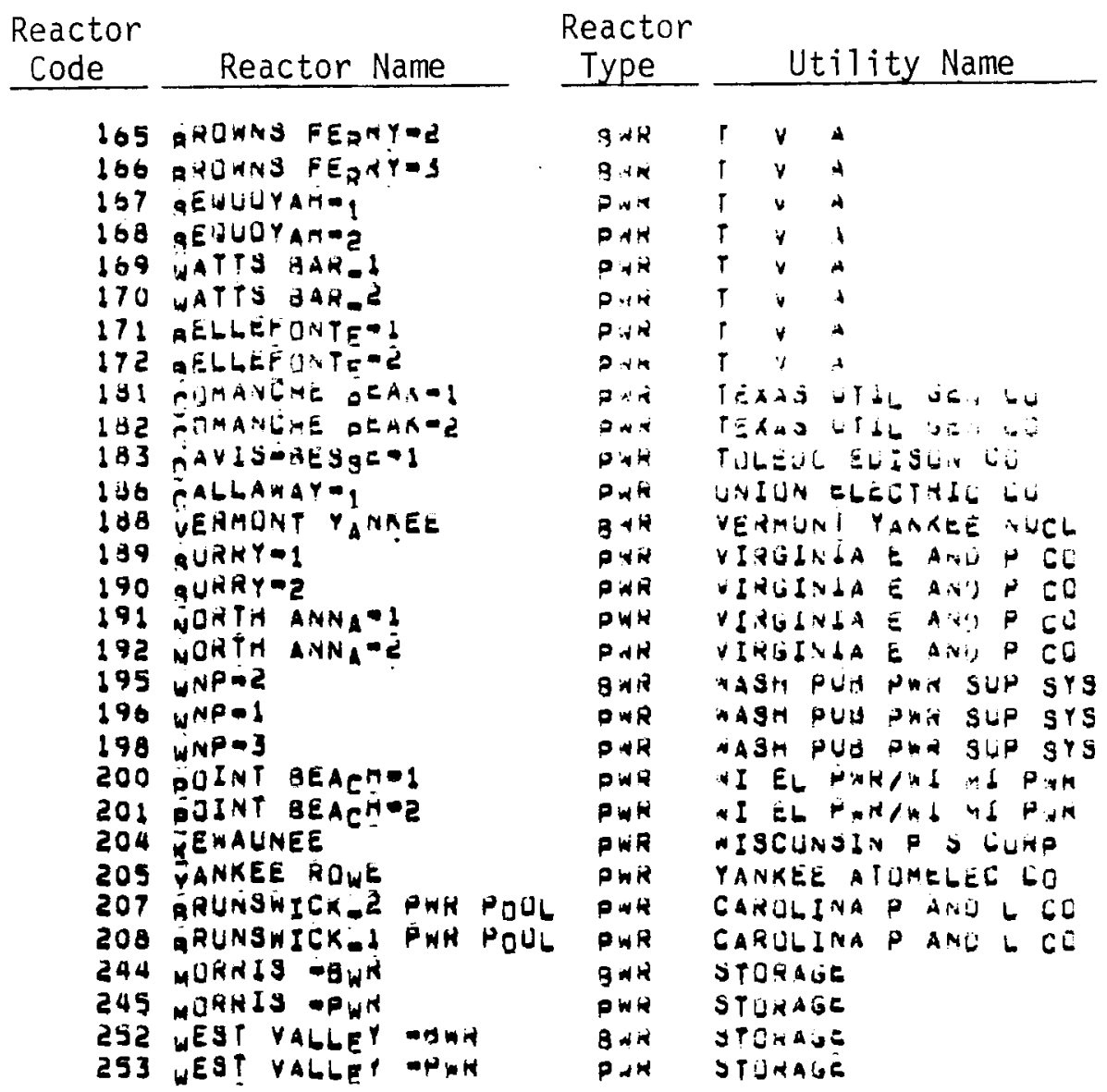




\section{Card Type 1}

Card

Column

Description

Format

1-5 Reactor ID code. This is a unique code assigned I5 to each reactor in the Spent Fuel Data Base

6-25 Reactor Name

28-30 Reactor Type (PWR or BWR)

31-35 Power, MWe Net

F5

67-70 Startup Year

Card Type 2

Card

Column

Description

Format

1-5 Reactor ID number where this spent fuel will be stored. This number will usually be equal to the reactor number in card 1 except when water basins are shared.

6-10 Pool inventory as of December 31, 1981 Number of assemblies

16-20 Reactor core size - Number of assemblies I5

21-25 Current pool capacity or initial pool capacity for planned reactors - Number of assemblies

26-30 Licensed pool capacity - Number of assemblies

31-35 Maximum pool capacity - Number of assemblies

36-40 Pool capacity after first planned expansion Number of assemblies

42-45 Year of first planned pool expansion

46-50 Pool capacity after second, third, and fourth

52-55 Year of second, third, and fourth planned pool

62-65 expansions 
Discharge Cards (one for each discharge)

Card

Column

2-5 Discharge year

9-10 Discharge month

11-15 Number of assemblies discharged
Description

Format

I 4

I2

I5

\section{B.2 Data Set 2: Case Control Parameters}

This data set describes the case to be run. Included are facility times, receiving rates, and parameters that describe the transportation system. The first card in Data Set 2 is a case title card. The entire card can be used to describe the case. It is printed on the shipment summary report.

The next group of card inputs defines a set of variables and arrays using the standard FORTRAN input scheme called "namelist" input. This scheme is described in any FORTRAN reference manual. A standard set of rules must be observed in this input convention. The name-list set is called CONTRL. The first card must have \$CONTRL in columns 2 through 8 and the last card must have \$END in columns 2 through 5 . The cards between those two cards define the following variables and arrays. In the variable definitions below, the first set of parentheses following array names defines the subscript and the second set of parentheses contains the maximum dimensions of the array. MYR is a FORTRAN parameter (used as a constant at program compilation time) for maximum number of years in the model and is presently set at 20.

In the variable definitions given below, the subscripts have the following significance:

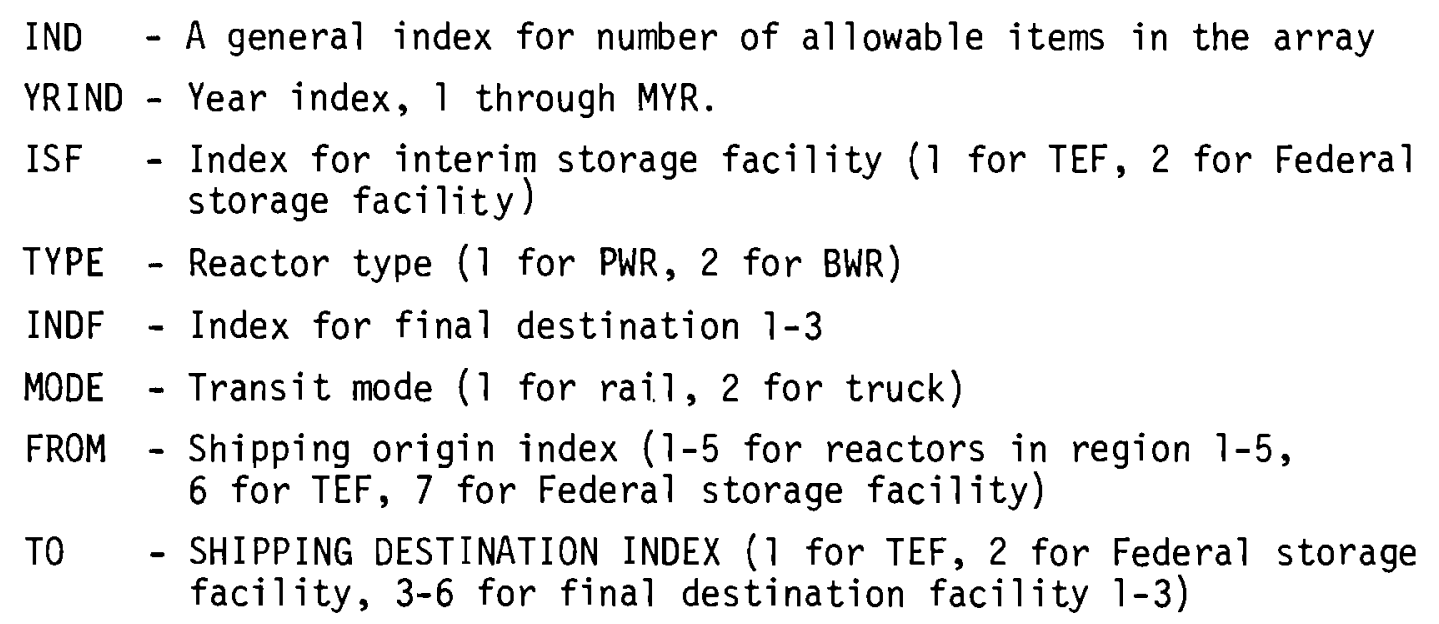


Variable Definitions

LFIRST - First year of analysis. This must be consistent with the year of the spent fuel inventory defined in the spent Fuel Discharge file (described in Table A.1), presently 1981 .

LAST - Last year of analysis. If last is greater than LFIRST + MYR - 1, it is effectively set to that value.

NFRP - Number of final destination facilities that will be receiving spent fuel shipments.

LFYFIS - Index of the year the Federal interim storage site is available. LFYFIS $=4$ if it starts in 1984 and LFIRST $=$ 1981.

IRSH (IND) (10)

- The reactor codes for user-specified shipments. This array is used in conjunction with NASH.

NASH (YRIND, IND, ISF) (MYR 10, 2)

- Number of assemblies shipped per user specification. The value specified in array IRSH is the reactor code.

NASREC (YRIND, TYPE, INDF) (MYR, 2,3)

- Receiving rate (assemblies) at the final destination facilities.

FREM (YRIND, ISF) (MYR, 2)

- Fraction of total receipts at an interim storage site to be removed and shipped to the final destination.

DIST (FROM, TO) $(7,6)$

- Distance between facilities, one way miles

RFR - Fraction shipped by rail for reactors with the rail option.

SPEED (FROM, TO, MODE) $(7,6,2)$

- Average transit velocity varies with distance traveled, miles/day

TT (MODE) (2)

- Average time for loading plus unloading a shipping cask, days

DEM (MODE) (2)

- Demurrage cost, the cost charged by a carrier while the shipment is not in transit (TT), \$/day

SECCSM (MODE) (2)

- Security cost, \$/one-way miles

SECCSD (MODE) (2)

- Security cost, \$/day

SHCOST (FROM, TO, MODE) $(7,6,2)$

- Freight charge, \$/shipment

NAPS (TYPE, MODE) $(2,2)$

- Number of assemblies per shipment

HAND (MODE) (2)

- Handling change \$/shipment 


\section{B.3 Data Set 3: Region Specifications}

This data set is a set of card images that assigns reactors to regions and also indicates which reactors do not have rail sidings. Its format is:

\begin{tabular}{clc}
$\begin{array}{c}\text { Card } \\
\text { Column }\end{array}$ & \multicolumn{1}{c}{ Description } & Format \\
$1-5$ & Reactor code as shown in Table B.1 & 15 \\
$6-10$ & Geographic region 1-5 & 15 \\
$11-15$ & $\begin{array}{l}\text { No rail indicator (0 means the reactor has provisions } \\
\text { for rail service, 1 for no rail service) }\end{array}$ & 15
\end{tabular}

The last card is an end card and should have a reactor code larger than 260 , such as 999 . 
APPENDIX C

FREIGHT CHARGE RATES

FOR TRUCK AND RAIL

SPENT FUEL SHIPMENTS 
APPENDIX C

FREIGHT CHARGE RATES FOR TRUCK AND RAIL SPENT FUEL SHIPMENTS

This appendix contain the freight (shipping) charge rates for truck and rail spent fuel shipments. These charges are assessed by commercial carrier companies to deliver the spent fuel shipping systems and cargo to the terminal facilities. It should be noted that these charges are negotiable due to the current deregulation of the truck and rail carrier industries and are not necessarily the lowest charges applicable to a specific shipment. However, the freight charges contained in this appendix are considered representative of the current charges for shipping spent fuel.

\section{C.1 TRUCK FREIGHT CHARGE RATES}

It was indicated in Section 5.1 that the truck freight charges used in this study are from a single carrier company that services the 48 contiguous states and has the capability to comply with NRC safeguards and security regulations. The freight charge rates published by this carrier company are shown in Table C.1 (Tri-State Motor Transit Co. 1981). Note that these charges are assessed per 100 lbs. ( $45.45 \mathrm{~kg}$ ) of the commodity being transported, either an empty or loaded shipping system. The commodity weights used to calculate shipping charges are the combined weights of everything that must be placed on the flatbed trailer. This includes the weight of the shipping cask, spent fuel (if a loaded shipment), tie-downs, personnel barrier, and other ancillary equipment, but excludes the weight of the tractor and trailer. The empty and loaded shipping weights were previously discussed in Section E.6. The resulting truck freight charges were shown in Table 5.3 and will not be repeated here.

\section{C.2 RAIL FREIGHT CHARGE RATES}

Rail freight charges are much more complicated than truck freight charges. As indicated, the rail shipping charges used in this study are for rail general freight service. The information contained in this appendix is extracted from a recent report (Cole et al. 1982) that primarily used the DOE/Hanford Traffic

C. 1 
IABLE C.1 Truck Freight Rates for Spent Fue ${ }^{\text {(a) }}$

\begin{tabular}{|c|c|c|c|c|c|}
\hline $\begin{array}{l}\text { Miles- } \\
\text { Not Over }\end{array}$ & Ful1 & Empty & $\begin{array}{l}\text { Miles- } \\
\text { Not Over }\end{array}$ & Fu11 & Empty \\
\hline $\begin{array}{l}100 \\
110 \\
120 \\
130 \\
140\end{array}$ & $\begin{array}{l}1.52 \\
1.60 \\
1.61 \\
1.65 \\
1.71\end{array}$ & $\begin{array}{r}.98 \\
.98 \\
1.03 \\
1.06 \\
1.08\end{array}$ & $\begin{array}{r}950 \\
975 \\
1000 \\
1025 \\
1050\end{array}$ & $\begin{array}{l}4.68 \\
4.76 \\
4.84 \\
4.93 \\
5.10\end{array}$ & $\begin{array}{l}3.71 \\
3.81 \\
3.89 \\
4.01 \\
4.10\end{array}$ \\
\hline $\begin{array}{l}150 \\
160 \\
170 \\
180 \\
190\end{array}$ & $\begin{array}{l}1.77 \\
1.84 \\
1.90 \\
2.02 \\
2.07\end{array}$ & $\begin{array}{l}1.10 \\
1.11 \\
1.14 \\
1.17 \\
1.21\end{array}$ & $\begin{array}{l}1075 \\
1100 \\
1125 \\
1150 \\
1175\end{array}$ & $\begin{array}{l}5.20 \\
5.35 \\
5.46 \\
5.56 \\
5.72\end{array}$ & $\begin{array}{l}4.17 \\
4.27 \\
4.42 \\
4.48 \\
4.56\end{array}$ \\
\hline $\begin{array}{l}200 \\
225 \\
250 \\
275 \\
300\end{array}$ & $\begin{array}{l}2.16 \\
2.23 \\
2.35 \\
2.42 \\
2.49\end{array}$ & $\begin{array}{l}1.24 \\
1.31 \\
1.39 \\
1.40 \\
1.45\end{array}$ & $\begin{array}{l}1200 \\
1225 \\
1250 \\
1275 \\
1300\end{array}$ & $\begin{array}{l}5.80 \\
5.94 \\
6.07 \\
6.19 \\
6.31\end{array}$ & $\begin{array}{l}4.68 \\
4.76 \\
4.87 \\
4.96 \\
5.08\end{array}$ \\
\hline $\begin{array}{l}325 \\
350 \\
375 \\
400 \\
425\end{array}$ & $\begin{array}{l}2.59 \\
2.68 \\
2.73 \\
2.83 \\
2.94\end{array}$ & $\begin{array}{l}1.56 \\
1.60 \\
1.61 \\
1.65 \\
1.77\end{array}$ & $\begin{array}{l}1325 \\
1350 \\
1375 \\
1400 \\
1425\end{array}$ & $\begin{array}{l}6.41 \\
6.57 \\
6.66 \\
6.79 \\
6.91\end{array}$ & $\begin{array}{l}5.15 \\
5.25 \\
5.36 \\
5.45 \\
5.54\end{array}$ \\
\hline $\begin{array}{l}450 \\
475 \\
500 \\
525 \\
550\end{array}$ & $\begin{array}{l}3.02 \\
3.09 \\
3.19 \\
3.24 \\
3.32\end{array}$ & $\begin{array}{l}1.82 \\
1.90 \\
1.97 \\
2.12 \\
2.20\end{array}$ & $\begin{array}{l}1450 \\
1475 \\
1500 \\
1525 \\
1550\end{array}$ & $\begin{array}{l}7.01 \\
7.17 \\
7.27 \\
7.38 \\
7.53\end{array}$ & $\begin{array}{l}5.63 \\
5.75 \\
5.82 \\
5.95 \\
6.05\end{array}$ \\
\hline $\begin{array}{l}575 \\
600 \\
625 \\
650 \\
675\end{array}$ & $\begin{array}{l}3.44 \\
3.51 \\
3.60 \\
3.67 \\
3.76\end{array}$ & $\begin{array}{l}2.29 \\
2.39 \\
2.50 \\
2.62 \\
2.66\end{array}$ & $\begin{array}{l}1575 \\
1600 \\
1625 \\
1650 \\
1675\end{array}$ & $\begin{array}{l}7.63 \\
7.77 \\
7.90 \\
7.98 \\
8.13\end{array}$ & $\begin{array}{l}6.12 \\
6.21 \\
6.33 \\
6.41 \\
6.52\end{array}$ \\
\hline $\begin{array}{l}700 \\
725 \\
750 \\
775 \\
800\end{array}$ & $\begin{array}{l}3.84 \\
3.93 \\
4.01 \\
4.08 \\
4.16\end{array}$ & $\begin{array}{l}2.72 \\
2.89 \\
2.98 \\
2.03 \\
3.11\end{array}$ & $\begin{array}{l}1700 \\
1725 \\
1750 \\
1775 \\
1800\end{array}$ & $\begin{array}{l}8.24 \\
8.35 \\
8.49 \\
8.59 \\
8.73\end{array}$ & $\begin{array}{l}6.61 \\
6.79 \\
6.87 \\
6.98 \\
7.11\end{array}$ \\
\hline $\begin{array}{l}825 \\
850 \\
375 \\
900 \\
925\end{array}$ & $\begin{array}{l}4.26 \\
4.31 \\
4.44 \\
4.49 \\
4.57\end{array}$ & $\begin{array}{l}3.22 \\
3.30 \\
3.39 \\
3.50 \\
3.63\end{array}$ & $\begin{array}{l}1825 \\
1850 \\
1875 \\
1900 \\
1925\end{array}$ & $\begin{array}{l}8.84 \\
8.96 \\
9.08 \\
9.23 \\
9.34\end{array}$ & $\begin{array}{l}7.17 \\
7.25 \\
7.37 \\
7.50 \\
7.57\end{array}$ \\
\hline
\end{tabular}

(a) Updated Apri1 22, 1982

(b) Source: Tri-State Motor Transit Co., Docket MC-109397.

Item No. 2000, First Revision. 
TABLE C. 1 (continued)

RATES IN DOLLARS PER 100 POUNDS

\begin{tabular}{|c|c|c|c|c|c|}
\hline $\begin{array}{l}\text { Miles- } \\
\text { Not Over }\end{array}$ & Ful1 & Empty & $\begin{array}{l}\text { Miles- } \\
\text { Not Over }\end{array}$ & Fu11 & Empty \\
\hline $\begin{array}{l}1950 \\
1975 \\
2000 \\
2025 \\
2050\end{array}$ & $\begin{array}{l}9.43 \\
9.60 \\
9.68 \\
9.83 \\
9.94\end{array}$ & $\begin{array}{l}7.64 \\
7.76 \\
7.84 \\
7.93 \\
8.05\end{array}$ & $\begin{array}{l}3200 \\
3250 \\
3300 \\
3350 \\
3400\end{array}$ & $\begin{array}{l}15.53 \\
15.77 \\
16.02 \\
16.22 \\
16.49\end{array}$ & $\begin{array}{l}12.55 \\
12.78 \\
12.92 \\
13.14 \\
13.35\end{array}$ \\
\hline $\begin{array}{l}2075 \\
2100 \\
2125 \\
2150 \\
2175\end{array}$ & $\begin{array}{l}10.07 \\
10.19 \\
10.30 \\
10.40 \\
10.56\end{array}$ & $\begin{array}{l}8.16 \\
8.24 \\
8.32 \\
8.44 \\
8.53\end{array}$ & $\begin{array}{l}3450 \\
3500 \\
3550 \\
3600 \\
3650\end{array}$ & $\begin{array}{l}16.74 \\
16.98 \\
17.20 \\
17.45 \\
17.69\end{array}$ & $\begin{array}{l}13.53 \\
13.72 \\
13.91 \\
14.12 \\
14.33\end{array}$ \\
\hline $\begin{array}{l}2200 \\
2250 \\
2300 \\
2350 \\
2400\end{array}$ & $\begin{array}{l}10.67 \\
10.92 \\
11.16 \\
11.40 \\
11.65\end{array}$ & $\begin{array}{l}3.65 \\
8.82 \\
9.04 \\
9.23 \\
9.42\end{array}$ & $\begin{array}{l}3700 \\
3750 \\
3800 \\
3850 \\
3900\end{array}$ & $\begin{array}{l}17.95 \\
18.18 \\
18.42 \\
18.64 \\
18.92\end{array}$ & $\begin{array}{l}14.48 \\
14.74 \\
14.92 \\
15.11 \\
15.29\end{array}$ \\
\hline $\begin{array}{l}2450 \\
2500 \\
2550 \\
2600 \\
2650\end{array}$ & $\begin{array}{l}11.91 \\
12.10 \\
12.35 \\
12.60 \\
12.85\end{array}$ & $\begin{array}{r}9.62 \\
9.83 \\
10.00 \\
10.21 \\
10.39\end{array}$ & $\begin{array}{l}3050 \\
4000 \\
4050 \\
4100 \\
4150\end{array}$ & $\begin{array}{l}19.16 \\
19.41 \\
19.63 \\
19.87 \\
20.10\end{array}$ & $\begin{array}{l}15.50 \\
15.69 \\
15.92 \\
16.09 \\
16.29\end{array}$ \\
\hline $\begin{array}{l}2700 \\
2750 \\
2800 \\
2850 \\
2900\end{array}$ & $\begin{array}{l}13.09 \\
13.34 \\
13.57 \\
13.83 \\
14.05\end{array}$ & $\begin{array}{l}10.61 \\
10.77 \\
11.00 \\
11.18 \\
11.39\end{array}$ & $\begin{array}{l}4200 \\
4250 \\
4300\end{array}$ & $\begin{array}{l}20.38 \\
20.61 \\
20.84\end{array}$ & $\begin{array}{l}16.48 \\
16.65 \\
16.87\end{array}$ \\
\hline $\begin{array}{l}2950 \\
3000 \\
3050 \\
3100 \\
3150\end{array}$ & $\begin{array}{l}14.32 \\
14.52 \\
14.79 \\
15.03 \\
15.27\end{array}$ & $\begin{array}{l}11.53 \\
11.78 \\
11.96 \\
12.12 \\
12.32\end{array}$ & & & \\
\hline
\end{tabular}


Manager's office as the source of information. The Traffic.Managers used appropriate railroad tariffs except that recently established northeastern U.S. single car rates could reduce charges on shipments to, from, or within that region. Inter-regional rates were used for uniformity in the recent report.

It was disclosed in Section 5.1 that rail freight rates are often not uniform with the distance traveled and can be affected by such factors as competition between rail lines, topography, and state and local regulations. The methodology used by Cole et al. (1982) to determine consistent rail freight rates is as follows. First, several origin-destination combinations (shipping and receiving facilities) were defined. Then the freight charges assessed for transporting spent fuel between each origin and destination were determined by the DOE/Hanford Traffic Managers from appropriate tariffs except for the Northeastern region as previously discussed. These freight charges were then plotted on a freight rate (dollars per 100 lbs) vs. one-way shipping distance coordinate system. Since the charges for empty and loaded shipments are not the same, curves are obtained for both. Equations for the rail general freight costs were determined from these data as a function of the distance traveled and the commodity weight. The freight charge rate is only a function of distance and the equations developed by Cole et al. (1982) as shown below determine these rates.

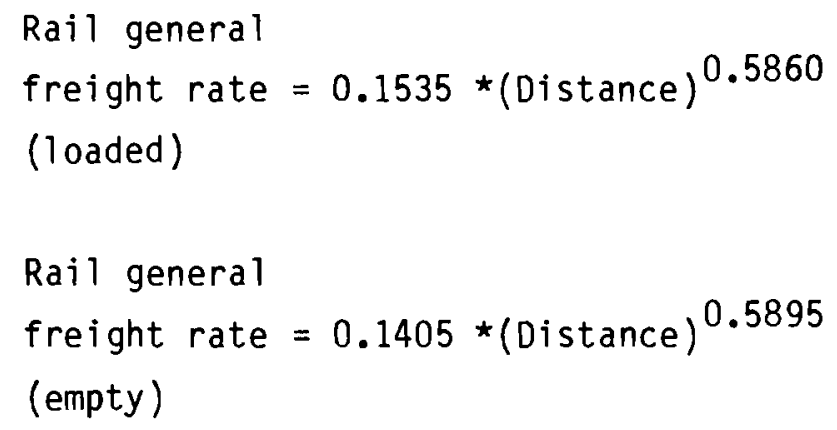

These equations represent a national average of the charge rates obtained by cole et al. (1982). The resulting freight rates for the assumed one-way 
shipping distances used in this study are shown in Table C.2. The freight costs calculated using the data in this table and the empty and loaded shipment commodity weights were previously shown in Section 5.6 and will not be repeated here.

\section{TABLE C.2 Rail General Freight Rates for} Spent Fuel Shipments $(a)$

Freight Rate (\$/100 1bs)

One-Way Shipping

Distance, $\mathrm{km}$ (mi.)

800 (500)

$\frac{\text { Loaded }}{5.86} \quad \frac{\text { Empty }}{5.48}$

$1200(750)$

7.43

6.96

1600 (1000)

8.79

8.24

$2400(1500)$

11.15

10.47

3200 (2000)

13.20

12.41

4000 (2500)

15.04

14.15

(a) Rates were calculated from data obtained by Cole et al. (1982). 


\section{REFERENCES FOR APPENDIX C}

1. Cole, B.M., Cross, R.E., Franklin, A.L., and Votaw, E.F. 1982. Truck, Rail, and Heavy Haul Charges for Shipping LWR Spent Fuel Casks. PNL-4064, TTC-0259, Pacific Northwest Laboratory, Richland, Washington.

2. Tri-State Motor Transit Co. 1981. Docket No. MC-109397. Joplin, Missouri. 
No. of

Copies

OFFSITE

R. Y. Lowrey

DOE Albuquerque Operations Office

P.0. Box 5400

Albuquerque, NM 87115

M. C. Kirkland, Project Manager

Production Systems

Spent Fuel Project office

DOE Savannah River Operations

P.0. Box A

Aiken, SC 29801

DOE Office of Spent Fuel

Management and Reprocessing Systems NE-40, GTN

Washington, D.C. 20545

ATTN: K. A. Klein

K. 0. Laughon

S. P. Schneider

27 DOE Technical Information Center

DOE Terminal Waste Disposal

and Remedial Action

NE20, GTN

Washington, DC 20545

ATTN: W. W. Ballard

F. Coffman

M. J. Lawrence

A. F. Perge

U.S. Dept. of Transportation

Materials Transportation Bureau

400 South Street, SW

Washington, DC 20590

ATTN: J. C. Allen

U.S. Nuclear Regulatory Commission Spent Fuel Storage Installation

Division of Fuel Cycle and

Material Safety

Washington, DC 20545
No. of

Copies

\author{
U.S. Nuclear Regulatory \\ Commission \\ Office of Nuclear Materials \\ Safety and Safeguards \\ Washingt on, DC 20555 \\ ATTN: N. H. Davison \\ J. Roberts
}

2 U.S. Nuclear Regulatory

Commission

Office of Nuclear Regulatory

Research

MS $5650 \mathrm{NL}$

Washington, DC 20555

ATTN: D. Reisenweaver

Argonne National Laboratory

9700 S. Cass Avenue

Argonne, IL 60439

ATTN: J. H. Kittel

C. J. Roberts

Lawrence Livermore National

Laboratory

P.0. Box 808

Livermore, CA 94550

ATTN: L. B. Ballou

Oak Ridge National Laboratory Union Carbide Corporation P.0. Box X

Oak Ridge, TN 37830

ATTN: L. D. Bates (2)

T. H. Rowe

Sandia National Laboratory

Transportation Technology

Center

Albuquerque, NM 87185

ATTN: G. C. Allen

R. M. Jefferson

R. B. Pope

C. G. Shirley 
No. of

Copies

Allied-General Nuclear Services P.0. Box 847

Barnwel1, SC 29812

ATTN: P. N. McCreery

P. F. Highberger

G. A. Townes

Auburn University

1167 Jenkins Drive

Auburn, AL 36830

ATTN: Professor B.A. Chin

Babcock \& Wilcox Co.

91 Sterling Avenue

P.0. Box 271

Barberton, $\mathrm{OH} 44203$

ATTN: Jerry Schulkraft

Battelle Memorial Institute Project Management Division Office of Nuclear Waste Isolation $505 \mathrm{King}$ Avenue

Columbus, $\mathrm{OH} 43201$

ATTN: S. Goldsmith

J. Carr

D. Stah1

Boeing Engineering and

Construction Company

625 Andover Park West

Tukwila, WA 98188

ATTN: K. Bjornerud

Carolina Power \& Light Co.

P.0. Box 1551

Raleigh, NC 27602

ATTN: R. Kunita

ChemNuclear Systems, Inc.

P.0. Box 1866

Bellevue, WA 98009

ATTN: D. G. Ebenback

Combustion Engineering, Inc.

C-E Power Systems

Windsor, CT 06095

ATTN: N. Fuhrman
No. of

Copies

Commonwealth Edison

Station Nuclear Engineering

Department

P.0. Box 767

Chicago, IL 60690

ATTN: G. P. Wagner

Consumers Power Company

1945 W. Parnall Road

Jackson, MI 49201

ATTN: F. W. Buckman, Executive Director, Nuclear Activities

Duke Power Co.

P.0. Box 33189

Charlotte, NC 28242

ATTN: R. Rasmussen

Edison Electric Institute 1111 19th Street, N.W. Washington, DC 20036

ATTN: R.E.L. Stanford

Electric Power Research

Institute

P.0. Box 10412

Palo Alto, CA 94304

ATTN: R. F. Williams

R. W. Lambert

Florida Power \& Light Co.

P.0. Box 013100

Miami, FL 33101

ATTN: R. Silva

General Atomic

P.0. Box 608

San Diego, CA 92112

ATTN: D. W. Ketchen

General Electric Company

Morris Operation

Morris, IL 60450

ATTN: E. E. Voiland 
No. of

Copies

Houston Lighting \& Power Co. Nuclear Fuels, Baybrook

P.0. Box 1700

Houston, TX 77001

ATTN: B. Handly

E. R. Johnson Associates, Inc.

11702 Bowman Green Drive

Reston, VA 22090

ATTN: E. R. Johnson

J. A. McBride

Maine Yankee Atomic Power Co. Edison Drive Augusta, ME 04336

ATTN: J. H. Garrity

Northeast Utilities Service Co. P.0. Box 270

Hartford, CT 06101

ATTN: R. Calabro

M. T. Pitek

Nuclear Assurance Corporation

24 Executive Park West

Atlanta, GA 30329

ATTN: J. Houston

J. Viebrock

NUS Corporation

910 Clopper Road

Gaithersburg, MD 20878

ATTN: B. D. Guilbeault

Portland General Electric

131 S.W. Salmon Street

Portland, OR 97204

ATTN: F. Rogan

Rockwell International

Rocky Flats Plant

TWSO T-690B

P.0. Box 464

Golden, C0 80401

ATTN: K. V. Gilbert
No. of

Copies

University of South Carolina College of Engineering

Col umbia, SC 29208

ATTN: A. Hill

Stanley Consultants, Inc.

Stanley Building

Muscatine, IA 52761

ATTN: J. A. Nevshemal

Tennessee Valley Authority

404 Krystal Building

Chattanooga, TN 37402

ATTN: J. B. Moegling

H. B. Brooks

Transnuclear

1 N. Broadway

White Plains, NY 10601

ATTN: W. R. Teer

J. Mangusi

Virginia Electric \& Power Co. P.0. Box 2666

Richmond, VA 23261

ATTN: D. C. Young

Westinghouse Electric Corp. P.0. Box 708

Mercury, NV 89023

ATTN: J. C. Dobbins

A. R. Hak 1

Westinghouse-Pittsburgh

Advanced Energy Systems Div. P.0. Box 10864

Pittsburgh, PA 15236

ATTN: R. J. Bahorich

\section{ONSITE}

3 DOE Richland Operations

office

P. A. Craig

H. E. Ransom

J. J. Schreiber 
No. of

Copies

4 Rockwell Hanford Operations

J. F. Albaugh

J. L. Deichman

R. J. Gimera

File Copy

Exxon Nuclear

S. J. Beard

Hanford Engineering

Development Laboratory

R. L. Knecht

R. E. Einziger

UNC/United Nuclear Industries

F. H. Bouse

41 Pacific Northwest Laboratory

W. B. Andrews

W. J. Bailey

T. D. Chikalla

B. M. Cole

J. M. Creer

P. M. Daling (10)

H. K. Edler

R. L. Engel (2)

J. F. Fletcher

M. D. Freshley

E. R. Gilbert

D. S. Jackson

A. B. Johnson, Jr.

W. S. Kelly

R. C. Liikala

R. P. Marshall

J. L. McElroy

D. F. Newman

A. M. Platt
No. of

Copies

R. E. Rhoads

K. J. Schneider

A. M. Sutey

W. R. Wiley

L. D. Williams

Technical Information (5)

Publishing Coordination (2) 